University of Louisville

ThinkIR: The University of Louisville's Institutional Repository

$5-2021$

\title{
Black men wanted: an instrumental case study exploring the situational factors related to the retention of African American male high school teachers.
}

Christopher Kevin Flores

University of Louisville

Follow this and additional works at: https://ir.library.louisville.edu/etd

Part of the Critical and Cultural Studies Commons, Curriculum and Instruction Commons, Educational Administration and Supervision Commons, Educational Leadership Commons, Educational Psychology Commons, Educational Sociology Commons, Industrial and Organizational Psychology Commons, Inequality and Stratification Commons, Race and Ethnicity Commons, Secondary Education Commons, Secondary Education and Teaching Commons, Social and Philosophical Foundations of Education Commons, Social Justice Commons, and the Sociology of Culture Commons

\section{Recommended Citation}

Flores, Christopher Kevin, "Black men wanted: an instrumental case study exploring the situational factors related to the retention of African American male high school teachers." (2021). Electronic Theses and Dissertations. Paper 3590.

https://doi.org/10.18297/etd/3590

This Doctoral Dissertation is brought to you for free and open access by ThinkIR: The University of Louisville's Institutional Repository. It has been accepted for inclusion in Electronic Theses and Dissertations by an authorized administrator of ThinkIR: The University of Louisville's Institutional Repository. This title appears here courtesy of the author, who has retained all other copyrights. For more information, please contact thinkir@louisville.edu. 


\title{
BLACK MEN WANTED: AN INSTRUMENTAL CASE STUDY EXPLORING THE SITUATIONAL FACTORS RELATED TO THE RETENTION OF AFRICAN AMERICAN MALE HIGH SCHOOL TEACHERS
}

\author{
By \\ Christopher Kevin Flores \\ B.A., University of Kentucky, 2005 \\ M.A., Georgetown College, 2006 \\ M.A., Eastern Kentucky University, 2011

\begin{abstract}
A Dissertation
Submitted to the Faculty of the College of Education and Human Development of the University of Louisville In Partial Fulfillment of the Requirements

for the Degree of
\end{abstract} \\ Doctor of Education \\ in Educational Leadership and Organizational Development \\ Educational Leadership, Evaluation and \\ Organizational Development \\ University of Louisville \\ Louisville, Kentucky
}

May 2021 
Copyright 2021 by Christopher Kevin Flores

All rights reserved 

BLACK MEN WANTED: AN INSTRUMENTAL CASE STUDY EXPLORING THE SITUATIONAL FACTORS RELATED TO THE RETENTION OF AFRICAN AMERICAN MALE HIGH SCHOOL TEACHERS

\author{
By \\ Christopher Kevin Flores \\ B.A., University of Kentucky, 2005 \\ M.A., Georgetown College, 2006 \\ M.A., Eastern Kentucky University, 2011 \\ A Dissertation Approved
}

March 22, 2021

by the following Dissertation Committee:

Dissertation Chair

Denise Cumberland, Ph.D.

Dissertation Co-Chair

Debbie Powers, Ed.D.

B. Keith Davis, Ed.D.

Douglas Stevens, Ph.D.

Lu Young, Ed.D. 


\section{DEDICATION}

This dissertation is dedicated to my wife and my children. Neomia, you have been the constant love, support, and encouragement I needed to get through this process. You challenged me to be a better researcher, educator, and advocate for those who are often unheard. Isaiah, Micah, and Amaya, you are my pride and joy and the reason I do this research. My hope is that you will have the privilege of being taught by more minority educators than your parents were. 


\section{ACKNOWLEDGMENTS}

\section{I can do all things through Christ who strengthens me (Philippians 4:13).}

Without the Lord's strength and guidance, I would have never been able to accomplish this milestone in my life. I have truly been blessed to be on this educational journey for three and a half years and there are so many individuals who have helped to elevate me to this point in my career.

I would like to thank my loving and supportive wife Neomia, who has been my champion in all things since the day we met almost 25 years ago. I could not have done this without you. You were the push I always needed when I was frustrated and wanted to give up. Along with my wife, my children remain the inspiration for my research. Isaiah, Micah, and Amaya, I am finally finished and I hope one day when you read this, you will be proud of your daddy.

To the rest of my family, there are too many of you to thank but I appreciate the guidance and support you have given me as a student, an educator, and as a man. I want to thank my parents, who at a very young age, although separately, instilled in me the value of education. To my mom and sister, specifically, your love and support has gotten me through so many milestones in my life and I am the person I am because of you two.

To the educational giants who guided me through this process and agreed to be on my committee, I thank you. Dr. Denise Cumberland, thank you for your positive, upbeat spirit and guiding me to become a better researcher and writer. Your vision for me as a 
Doctoral student was just what I needed. Dr. Deborah Powers, thank you for being that constant mom-like figure that our entire cohort relied on for guidance and support. I could not imagine this journey without you. Dr. Doug Stevens, thank you for being a listening ear who is just as passionate about my topic as I am. I consider you a colleague and friend and look forward to future collaborations. Dr. Keith Davis, thank you for your insight, your knowledge of educational leadership, and pushing each of us to be better leaders. Finally, Dr. Lu Young, thank you for your wisdom and for the mentoring you have given me throughout my time at STEAM and hopefully beyond.

To my fellow cohort members, it has been quite the journey we have all taken together. The classes and assignments were much more enjoyable with colleagues who were willing to help and support each other. A special thanks to Erin and Rachel who became my own mini-cohort of support. Without you two, I could not have made it through. Thank you for your friendship.

To my STEAM Academy family, I appreciate all the words of encouragement and check-ins throughout my time in this program. You each have made me a better leader and I value the relationships I have made with my work family.

Finally, to the 10 strong, educated, articulate, and inspiring African American men who participated in this study and made this research possible. Thank you for sharing your journey with me and providing insight and voice to a population that is often silenced. Even though our interviews only lasted an hour, each of you has had a lasting impact on my life. I hope that by having these "tough conversations," we can inspire change for future generations of minority students and educators. I am forever thankful. 


\title{
ABSTRACT \\ BLACK MEN WANTED: AN INSTRUMENTAL CASE STUDY EXPLORING THE SITUATIONAL FACTORS RELATED TO THE RETENTION OF AFRICAN AMERICAN MALE HIGH SCHOOL TEACHERS
}

\author{
Christopher K. Flores
}

March 22, 2021

As the nation's high school student population becomes increasingly diverse, the declining number of minority teachers, particularly African American male teachers is becoming an area of concern. This instrumental case study of African American male high school teachers in the Fayette County Public School system in Lexington, Kentucky sought to identify the motivations for teaching, the barriers prior to and during teaching, as well as the roles these individuals are asked to fulfill in their schools. Using purposeful sampling, 10 individuals participated in semi-structured interviews aimed at providing insight to the three research questions related to motivations, barriers, and roles.

Using Critical Race Theory as a theoretical framework, the interviews were transcribed and coded using both deductive and inductive coding to find emergent themes that would help to answer the research questions. The teachers' sense of altruism served as a leading theme for their motivations while school and neighborhood pressures, awareness of minority status and isolation were found as some of the main barriers to pursuing a career as an educator. Traditional roles focused on minority students such as 
mentor and typecast roles, such as disciplinarian, were found as roles that may contribute to a teacher's tenure as an educator.

These themes served as a guide to inform the implications and recommendations pertaining to this research, which sought to find solutions such as programming and more intentional recruitment and retention efforts aimed specifically at African American males. A key finding from the Black male educators in this study is the importance of altruistic influencers who helped propel these men into education and their personal desire to be allies for their own students. By expanding the conversation on race and racism within the educational system, this research sought to expose the injustices that African American male teachers experience not only during their time in school, but later during their careers as educators. This research gave voice to a silenced minority and expanded on the need for further investigation into why the educational system is always asking, "Where are the Black men?" 
TABLE OF CONTENTS

ACKNOWLEDGMENTS ........................................................

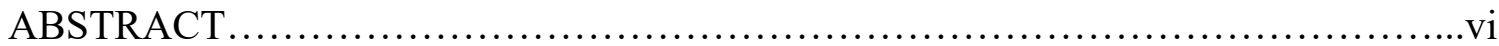

LIST OF TABLES .................................................................

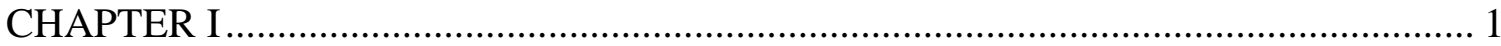

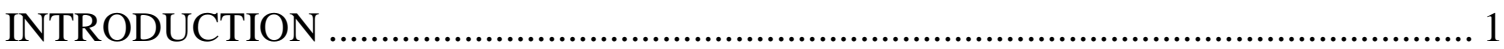

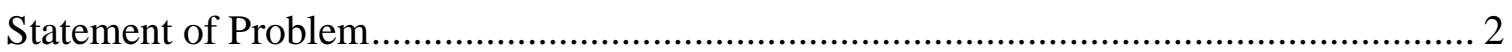

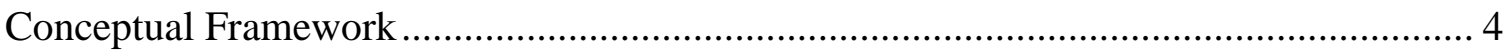

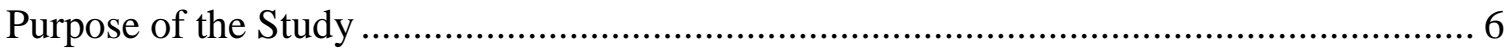

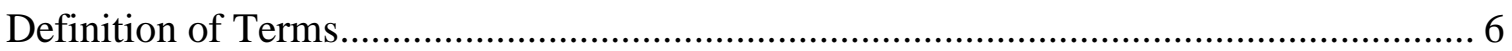

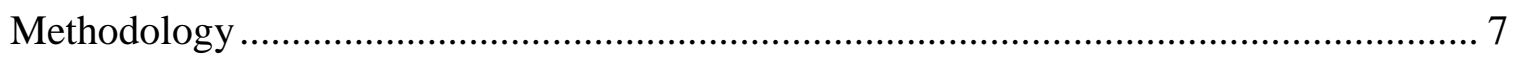

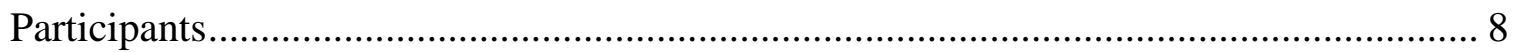

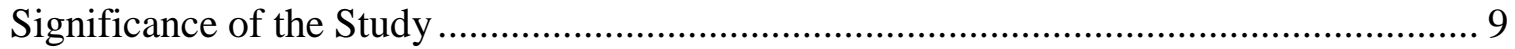

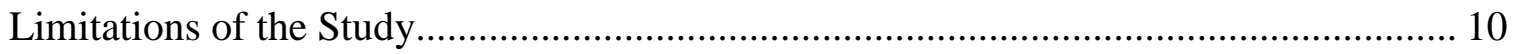

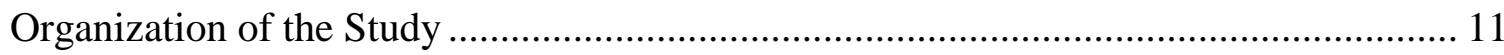

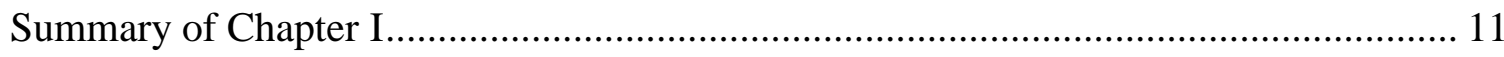

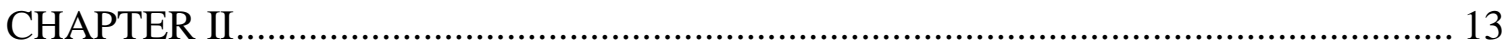

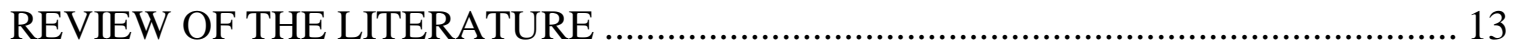

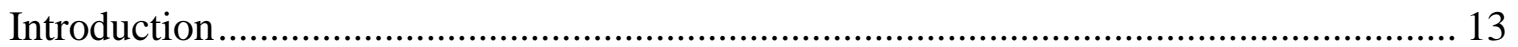

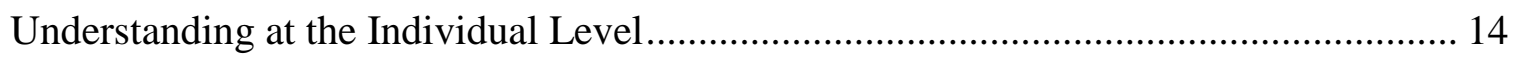


Obstacles for Entering the Teaching Profession

Motivations for Entering the Teaching Profession .................................................. 22

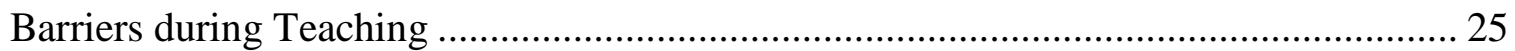

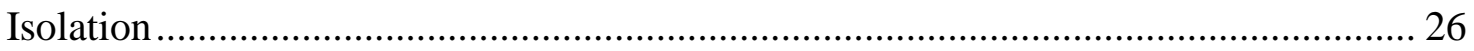

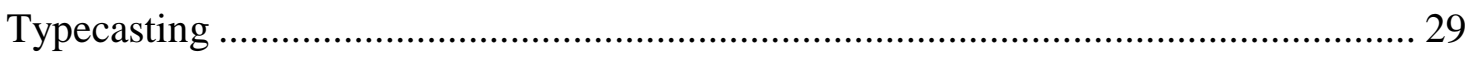

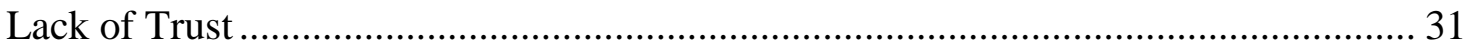

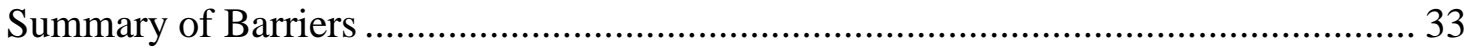

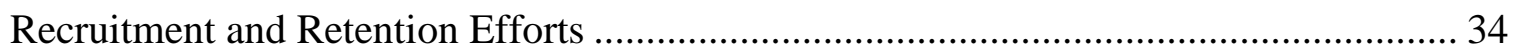

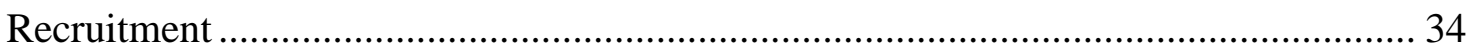

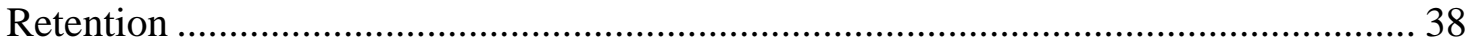

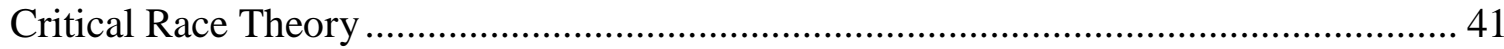

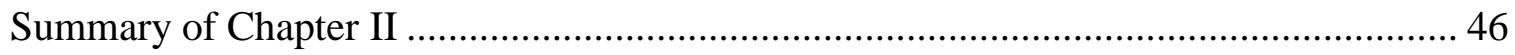

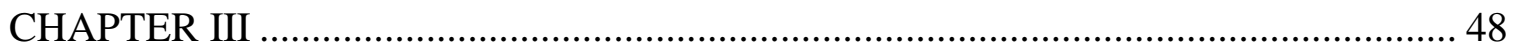

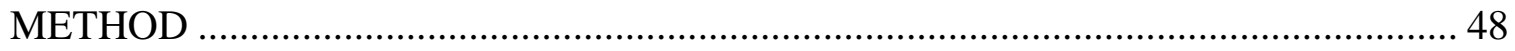

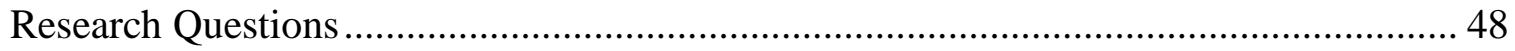

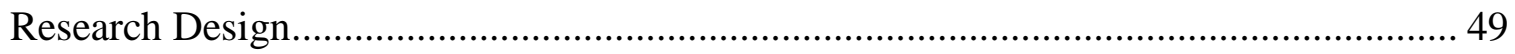

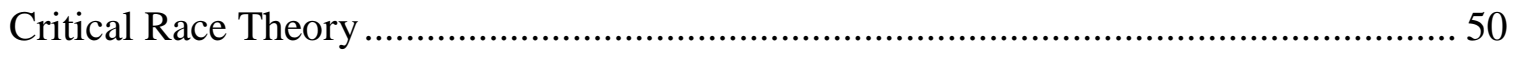

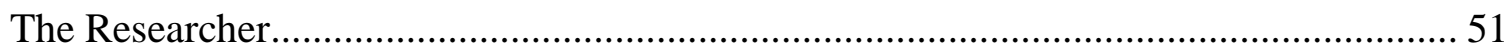

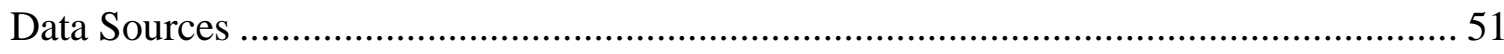

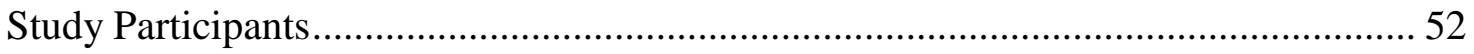




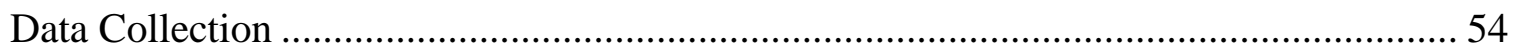

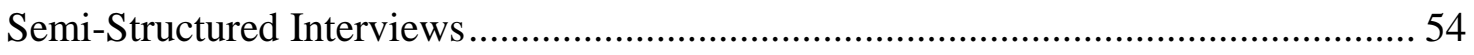

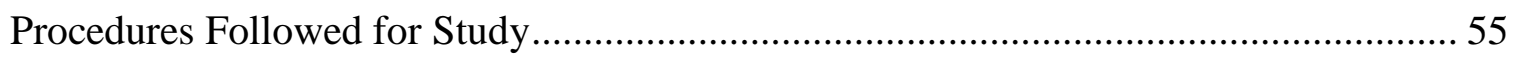

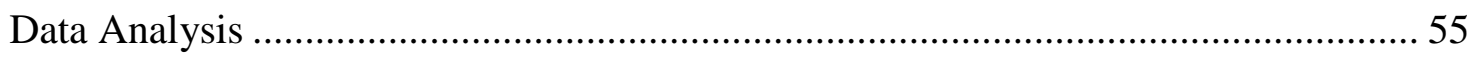

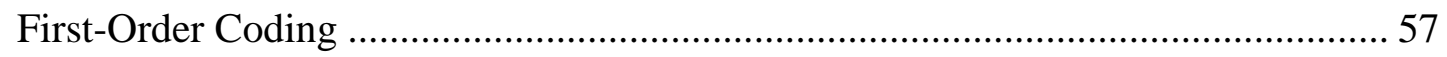

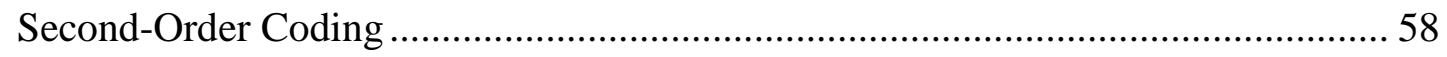

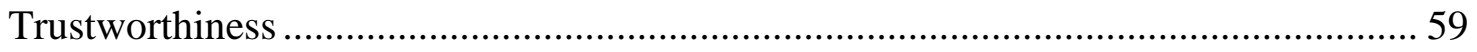

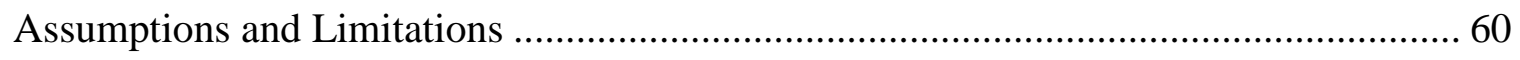

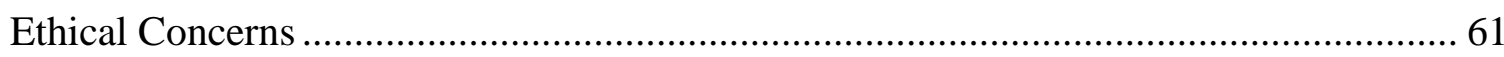

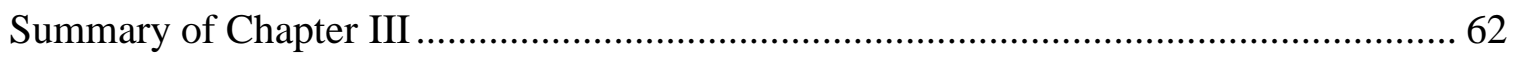

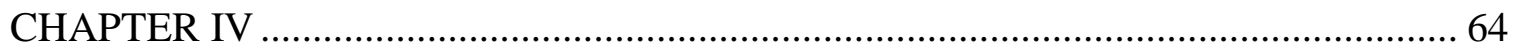

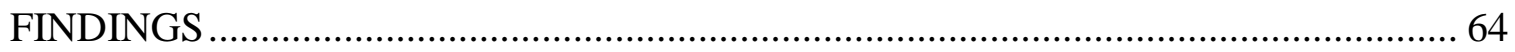

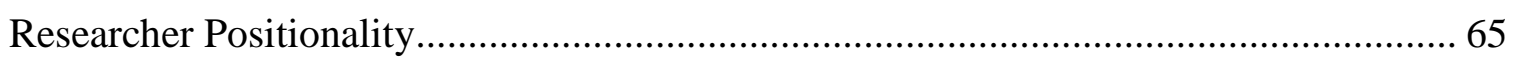

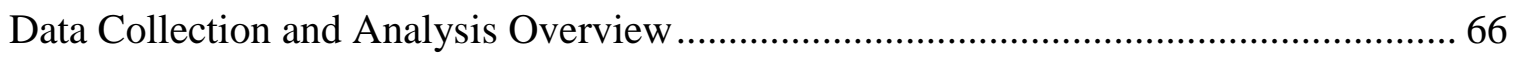

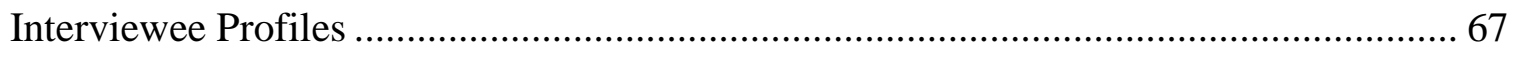

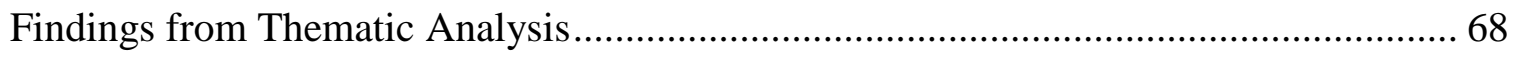

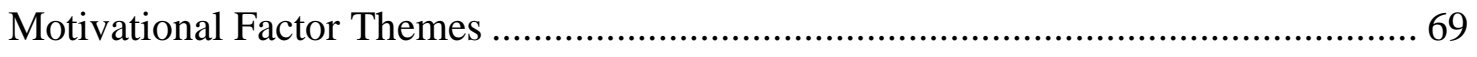

Why High School Teaching? ................................................................................. 72

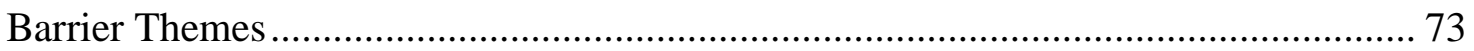

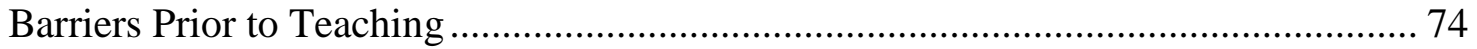


First-Order Codes.

Second-Order Codes................................................................................. 75

Summary of Barriers Prior to Teaching .................................................................. 78

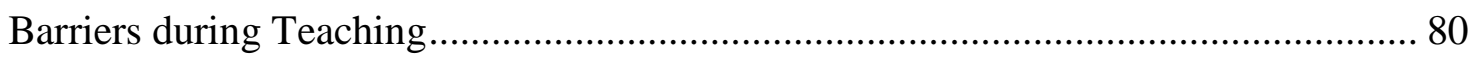

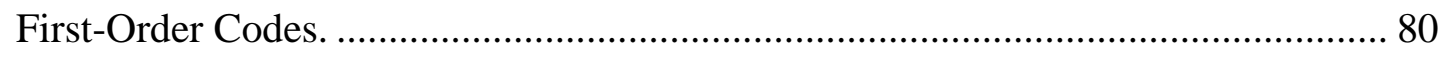

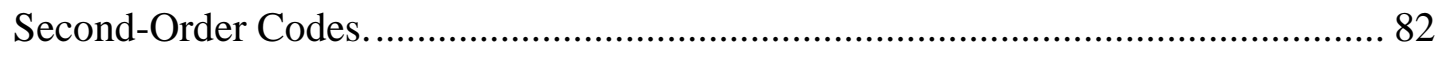

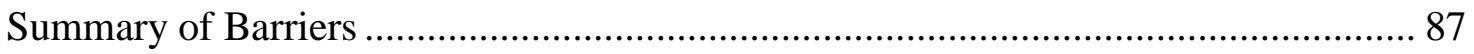

The Roles of an African American Male Teacher ............................................... 88

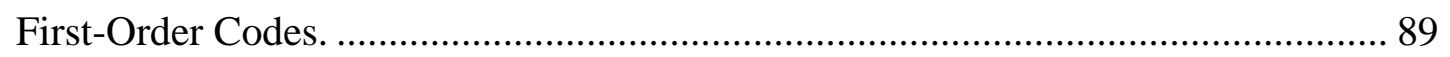

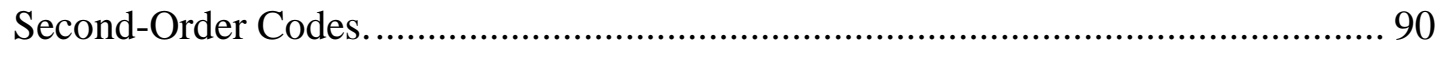

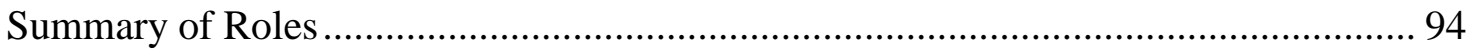

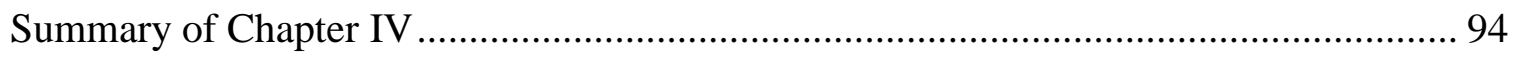

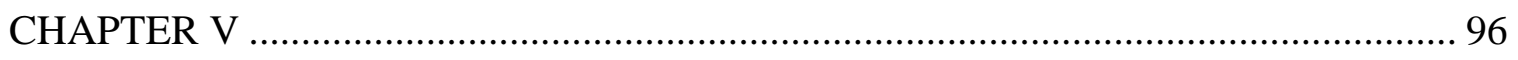

CONCLUSIONS, IMPLICATIONS, AND RECOMMENDATIONS FOR FUTURE

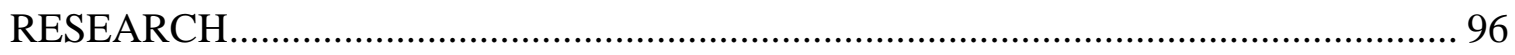

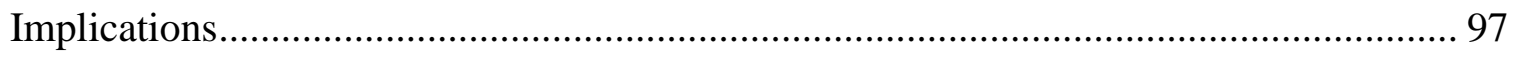

The Need to Encourage You African American Males to Pursue Teaching Early ....... 97

The Need to Address Barriers Preventing African American Males from Pursuing

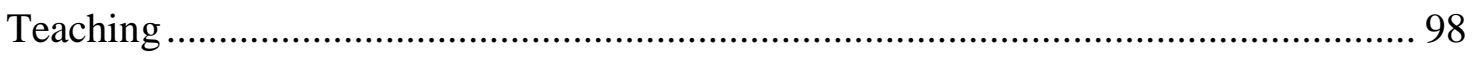

The Need to Address Implicit Bias ................................................................... 101 


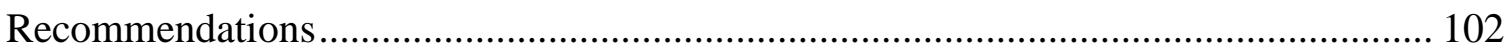

Recommendations for Fayette County ................................................................ 103

Recommendations Beyond Fayette County ........................................................... 106

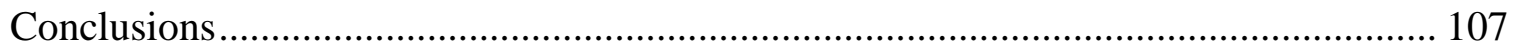

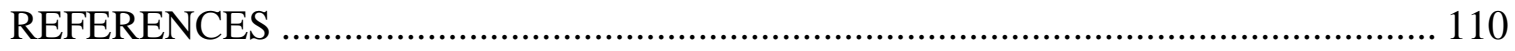

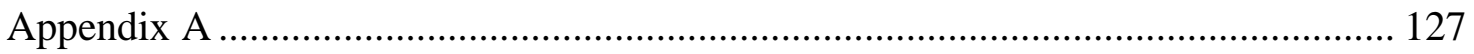

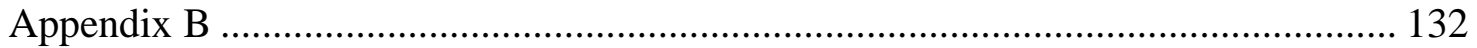

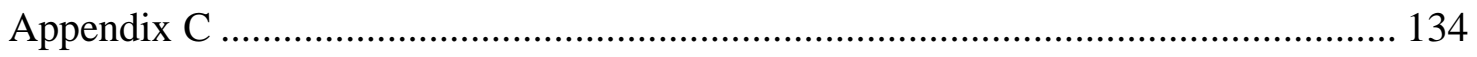

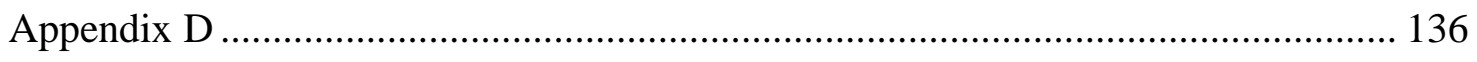

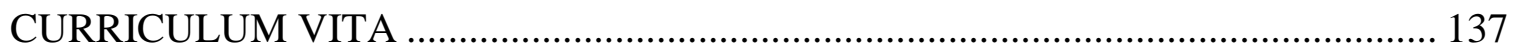




\section{LIST OF TABLES}

Table 1. Demographics of Interview Participants.........................................................67

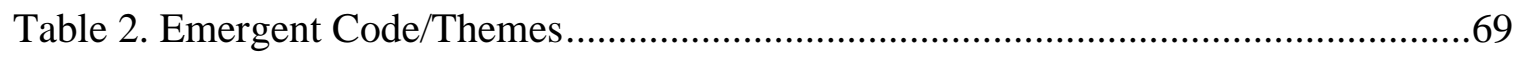

Table 3. Motivational Factor Themes Sample Quotes.......................................................72

Table 4. Barriers before Teaching Theme Sample Quotes ................................................79

Table 5. Barriers during Teaching Theme Sample Quotes...............................................86

Table 6. Roles of the Teacher Theme Sample Quotes..................................................93 


\section{CHAPTER I}

\section{INTRODUCTION}

Imagine you are a principal in a mid-sized city tasked with opening a new high school and hiring a staff to fulfill the needs of all students. As interview groups come and go and teachers start to be offered jobs, you notice something is missing. There are almost no minority teacher candidates interviewing for jobs and in particular, there are zero African American males in the pool of talent being vetted. As an educator, you realize the importance of hiring a diverse staff to mimic the demographics of the student population and you are wondering whether your situation is unique and, more importantly, what can be done to address the problem.

The scenario above is a reality for schools across the country. As the number of minority students populating classrooms continues to increase, there is a growing need to recruit and retain teacher candidates who look like, think like, and have some of the same experiences as their students (Boston \& Warren, 2017). According to the National Center for Education Statistics (2019), between the fall of 2015 and the fall of 2027, the percentage of students enrolled in public schools who are White is projected to decrease from forty-nine to forty-five percent. By the year 2027, minority students will make up the majority of students in public schools. Given this dramatic shift in the demographic make-up of students, the need to increase the number of minority teachers will be at an

all-time high. Positive academic results have been linked to a sense of belonging (Boston 
\& Warren, 2017) and studies have shown that when faculties are diverse, a student's sense of belonging can be enhanced by having a teacher of the same demographic (Booker, 2007; Madkins, 2011; Boston \& Warren, 2017). Learning from teachers of color can allow students of color the opportunity to see people who look like them in positions of power and influence (Kirk, 2017). If an African American male student in third, fourth, or fifth grade has a black teacher, he is thirty-nine percent less likely to drop out of high school (Kirk, 2017). These students are also more likely to attend a four-year college and this benefit can come from having only one black teacher throughout their education (Kirk, 2017). Students who do not have an African American male teacher are often denied perspective, guidance, and understanding that can only come from a Black male (Scott, 2016).

\section{Statement of Problem}

According to the Department of Education, less than two percent of the teachers in America are black men (Milner, 2018). Hence, in African American communities it is more likely that the teachers represent a different ethnicity (the majority are Caucasian and female) and have limited knowledge of the populations they serve (Boston \& Warren, 2017). This is problematic as it may lead to a feeling of disconnect on the part of the student and this disconnect may influence their feelings of belonging as well as suppress their academic achievement at school (Boston \& Warren, 2017).

The state of Kentucky is equally challenged with respect to diverse faculty. According to the 2016-2017 Kentucky State school report card, 10.6\% of the student population are from the African American minority group. As a state, only $3.5 \%$ of the teachers are African American, and this includes both males and females at all levels of 
teaching (elementary, middle and high school). For Fayette County Public Schools located in Lexington, Kentucky, $22.4 \%$ of the student population is classified as African American while only $7.4 \%$ of the teaching workforce in Fayette County is classified as African American (Kentucky Department of Education, 2018). STEAM Academy, a high school program located within Fayette County and an organization with which the researcher is employed is a school that has a larger African American population than most programs of its size. The school has approximately 340 students and $31.3 \%$ of those students are African American.

The increased population of African American students should attract a more diverse teaching force but at STEAM, in the 2016-2017 school year, only two teachers (8.3\%) were African American and only one of those teachers was male (Kentucky Department of Education, 2018). In the 2020-2021 school year, there were no African American males employed at STEAM Academy. When teaching applicants apply to Fayette County, they are often coded as minority applicants within the application hiring system. Hiring managers at the school level are able to view which applicants are selfreporting as minority. At STEAM Academy, why did this one African American male choose to go into the teaching profession and why are African American males as a whole choosing to go into high school teaching? While various studies (Brown, 2012; Dinkins \& Thomas, 2016; Jones, Holton \& Joseph, 2019; King, 1993) have focused on the motivational factors for entering the teaching profession, little research has been conducted with African American males once they are in the profession. To develop a better understanding of the lack of African American teachers, it is important to examine their experiences, including their successes, challenges, and factors that influence their 
decision to stay in the field. If the African American population of students being served in public high schools across STEAM Academy, the district, state, and nation is poised to continue increasing, then it is imperative that the minority-teaching workforce also increases. Greater understanding about the experience of African American males in the teaching profession and illuminating important factors that attract them to the profession will be of interest to colleges, universities, school districts and other educational entities aimed at increasing diversity in the workforce.

\section{Conceptual Framework}

Critical Race Theory (CRT) served as the guiding theoretical framework for this qualitative examination of African American males who work in the public high school education system. CRT focuses attention on the relationships between race, racism, and power (Creswell \& Poth, 2018). One goal of CRT is to address areas of difference such as gender, race, class, and any other inequities experienced by the participants or individuals who are being studied (Creswell \& Poth, 2018). In this instrumental case study, the reasons why African American high school teachers in Fayette County chose teaching were explored as well as the barriers they face and the roles they fulfill in their profession. This research attempted to explain the experiences of people of color and offer transformative solutions to some of the inequities in society (Creswell \& Poth, 2018).

CRT aligned with this research because there could be underlying racism and prejudice associated with the hiring and retention of minority teachers at the high school level, as well as microaggressions experienced by the individuals at the hands of their colleagues, administrators, students, and parents. Most people have been socialized 
through racially biased systems of education and as a result, many individuals carry a skewed view of minority and ethnic groups that are non-white (Kohli, 2008). Teacher education programs that are attempting to recruit teachers of color will also need to reflect on their own thoughts of White cultural superiority, and how this may shape their worldviews when trying to recruit minority candidates into their programs (Kohli, 2008).

CRT challenges the discussions on race and racism as they pertain to the educational world because it examines how different theories and practices are used to marginalize certain minority or ethnic groups. After all, race and racism have become so ingrained in everyday thought that it has started to become normal (Milner, 2007). Schools may be attempting to hire and recruit minority teachers, but are their attempts only surface level? Critical Race theorists call upon individuals to reflect on the explicit and implicit biases they possess and create policies and avenues to eliminate the racism that might be found in their recruitment, hiring practices, and later in their work environments (Milner, 2007).

There are five guiding principles to CRT: centralizing race and racism, challenging dominant ideology, a commitment to social justice, valuing lived experiences, and using interdisciplinary perspectives like sociology and psychology (Kohli, 2008). One of the most important features of this research study was the exploration of principle number four of CRT, valuing lived experiences. The research participants in this study were current educators representing the African American male community. Their experiences navigating the decision to teach and later the barriers faced in continuing to teach were the topics that were highly valued in this research. Through their experiences, readers can identify the implicit and explicit bias and racism 
these participants have experienced and why they have continued to endure in the teaching arena.

\section{Purpose of the Study}

The purpose of this qualitative, instrumental case study was to discover the reasons African American males choose high school teaching and what barriers they face not only on their journey to become a teacher, but once they assume the role. This study also attempted to explore the roles they are asked to fulfill in their work setting outside of their regular teaching responsibilities and consider if those roles contribute to their retention. This study consisted of interviews with African American males from Fayette County, Kentucky who were employed as public school teachers. The total number of interviewees depended on reaching saturation and semi-structured interview questions were used. Through these interviews, these individuals provided insight into the lived experiences of an underrepresented population of teachers.

The specific research questions guiding this study include:

RQ1. Why are African American males pursuing a career in high school education?

RQ 2. What barriers do African American males face prior to and during their teaching careers?

RQ 3. How do the roles African American males are asked to fulfill contribute to their tenure as a teacher?

\section{Definition of Terms}

African American: Also termed as Black. These individuals are an ethnic group with total or partial ancestry from any of the black racial groups in Africa. 
Urban Schools: Schools located in or near urban centers, primarily serving poor and ethnically diverse students in densely populated areas. Urban schools are often characterized by lower academic achievement than suburban schools, and high rates of mobility by students.

Racism: Prejudice, discrimination, or antagonism directed against someone of a different race based on the belief that one's own race is superior.

Microaggressions: A statement, action, or incident regarded as an instance of indirect, subtle, or unintentional discrimination against members of a marginalized group such as a racial or ethnic minority (DeCuir-Gunby \& Gunby, 2016).

Historically black colleges and universities (HBCUs): Institutions of higher education in the United States that were established before the Civil Rights Act of 1964 with the intention of primarily serving the African American community.

Critical Race Theory: Is a theoretical and interpretive mode that examines the appearance of race and racism across dominant cultural modes of expression (Lynn, 2002).

Instrumental Case Study: A study of a case (e.g., person, specific group, occupation, department, organization) to provide insight into a particular issue, redraw generalizations, or build theory (Baxter \& Jack, 2008).

\section{Methodology}

The qualitative research design selected for this study was an instrumental case study. In an instrumental case study, the researcher focuses on a particular issue or concern and then selects a case to demonstrate the issue (Creswell \& Poth, 2018). A case study was chosen because it is an empirical form of inquiry that investigates a phenomenon within a real-life context and becomes a comprehensive research strategy 
(Yin, 1994). The case that is selected in a case study may be an individual, small group or an organization (Creswell \& Poth, 2018). According to Creswell and Poth (2018), a case study explores a real-life issue over time through detailed data collection and involves multiple data sources such as observations, interviews, documents and reports. A key component to case study work is that it remains bounded, meaning that it has defined and specific parameters (timeframe and place) (Creswell \& Poth, 2018). At the end of a case study, a conclusion develops that contains assertions about the researched topic (Creswell \& Poth, 2018).

An instrumental case study was chosen as the research design as it enables exploration of a troubling issue by identifying the commonalities and differences within the boundaries of the case (Stake, 1995). In this specific study, the educational journeys of African American male high school teachers in Fayette County, KY were explored.

\section{Participants}

The participants for this research were selected based on purposeful sampling, which allowed for a broader research base in regards to the participants, so that the participants span different years in the profession, different content specialties, and different schools site context (Baxter \& Jack, 2008). The human resources department for Fayette County Public Schools was contacted and a request for a list of all male minority teachers at the high school level and the name of their school was generated. Years of teaching experience was also included in the report. Human resources was assured the list was intended for research purposes only and the names of the participants were not to be used. Once the list was received, all males designated as non-African American were eliminated from the study. From the remaining list, teachers were purposefully selected to 
provide the research with a larger data set as it pertains to years of experience. After the list was finalized, the participants were contacted to set up interviews. While the final number of participants in this study was determined by saturation, the limited number of African American male high school teachers in Fayette County suggested the highest number may not have exceeded 25 . The researcher attempted to solicit at least 10 participants to ensure anonymity of the participants.

During the interview process, participants were asked semi-structured questions that would elicit a response composed of more than a few words. Semi-structured interview questions were used so that the researcher did not insert bias into the interview process. During the interviews, a more open structured format was used to allow the researcher to interject questions into the interview process based on the responses the participants gave.

After the interview was complete and the transcripts of the interview were formalized, the complete transcript was sent to the participants by email so that they could confirm the accuracy of their statements. Once the interviews had been reviewed by participants, analysis began with the coding of the interviews to find emerging themes. These themes helped determine the recommendations made later in the study.

\section{Significance of the Study}

Schools and districts across Kentucky and the United States recognize the importance of having male teachers of color in the classroom and spend time and money focused on attracting this talent pool. While an accomplishment, recruitment does not suggest victory. Retention of this talent pool is paramount to ensuring the school, district, and most importantly, the students have access to a diverse pool of teachers and mentors. 
This study was significant because it provided insight into the daily barriers and roles that African American males experience in their profession and how that affects retention. By understanding the barriers and roles African American males face in their teaching careers, HR departments, schools, and colleges can create interventions to eliminate the barriers that these individuals encounter.

\section{Limitations of the Study}

As this research took place, it was important to note what beliefs and assumptions are held about the researcher, the research subjects, and the audience (Glense, 2016). As I developed the questions and interview protocol, it was important for me to remember my beliefs about the lack of minority male teachers in the high school classroom. As a minority male, it was important to make sure that my personal experiences in education did not affect the research process. I have a strong desire to see more minority males in the high school classroom and so I needed to ensure that my opinions did not come through in the interview process but rather, let the participants tell their stories so that the audience and the researcher could form their own opinions about the research topic. I was aware that my bias may place some limitations and weaknesses in the research, especially as I searched for research pertaining to barriers in education rather than successes.

Fayette County, though large, had a limited number of African American males who teach at the high school level. Therefore, the pool of interview candidates for this research study was limited. The small sampling of participants may not have been representative of all African American male experiences in high school and so to strengthen the research, a broader sampling of individuals may have been necessary, along with a larger sampling in regards to geographical area. 
Another limitation for this study was choosing participants who only teach at the high school level. A more comprehensive study may have included individuals from all levels of teaching (elementary, middle and high school).

\section{Organization of the Study}

This study is composed of five chapters. Chapter I is an introduction to the study of African American males in high school education. Chapter II is a comprehensive review of the literature on African American males, their career choices, and the barriers they face in the education profession. An additional focus of Chapter II is on the roles African Americans fulfill in their schools/districts and how these roles influence retention in the teaching profession. Critical Race Theory (CRT) is reviewed as this is the theoretical lens being used in this study to excavate how race and racism impact African American men who pursue the teaching profession. Chapter III focuses on the research design, methodologies, and participants and how the study was conducted, while Chapter IV explores the research of the study and explains the results in detail. Finally, Chapter V provides an interpretation of the research, implications for further research in this area and a summary of the entire research study.

\section{Summary of Chapter I}

This study extends prior research on the motivational factors of African American males and the research pertaining to their choice to enter the teaching profession, more specifically high school education. Importantly, the research advances our understanding of what these individuals experience once they are employed in the school system, and how the roles they fulfill once in their profession impacts retention in the profession. The information found in this study can be beneficial to college education preparation 
programs preparing students to enter into the academic workforce, school district Human Resource departments, and individuals seeking to recruit and retain male teachers of color. 


\section{CHAPTER II}

\section{REVIEW OF THE LITERATURE}

\section{Introduction}

A nationwide survey from the National Center for Education Statistics found that minority teachers in the United States during the 2017-2018 school year comprised only $16 \%$ of the US teaching workforce (NCES, 2020). Breaking this down further, of the estimated 3.1 million public school teachers in the United States, only $2.0 \%$, or approximately 60,000, of those teachers were African American men (Milner, 2018). African American students, however, comprise approximately $16 \%$ of public school student enrollment; hence, the percentage of African American male teachers is not proportional to the number of African American students currently sitting in classrooms (Milner, 2018). The 2.0\% of African American men in teaching positions spans all levels of education (elementary and secondary). Further, African American males tend to teach in urban school districts with high minority populations (Ingersoll \& May, 2016). As these individuals tend to teach in urban school districts, many suburban and rural school districts are left devoid of African American male teachers.

Chapter II examines academic research efforts undertaken to explain these phenomena. The literature review delineates three main areas related to the overall research questions. In the first section, an examination at the individual level explored: (a) obstacles for entering the teaching profession (b) motivations for choosing the 
teaching profession and (c) possible barriers these individuals faced before and during teaching, including the roles they are asked to fulfill. The second section of the literature review identified what has been occurring with respect to recruitment and retention of African American male teachers at the high school level. Finally, the literature review concluded by examining Critical Race Theory (CRT), which serves as the theoretical lens for this research study.

\section{Understanding at the Individual Level}

\section{Obstacles for Entering the Teaching Profession}

Over the last quarter century, scholars have explored why African American males are woefully underrepresented within the teaching pipeline. Early work by Allen and Boykin (1992) points to systematic issues that surface when young black boys begin schooling. These scholars argue that much of the failure exhibited by African American children can be explained by cultural discontinuity, where educational systems often do not support the salient features that are cultivated in the African American home. These researchers argue that since pedagogy in the United States is founded upon mainstream ideas, the traditional classroom is lacking in outlets for expressions of Afro-cultural behaviors, thus lending to the perception that the most salient aspects of the lives of African American children are not valued or relevant in the educational setting (Allen \& Boykin, 1992). As a result of these breakdowns, including the lack of diversity in the school with respect to students and staff, and a lack of cultural language and pedagogy, many African American children experience a disconnect at school and therefore have a negative impression of the educational system. 
These negative experiences in school lend themselves to greater issues facing African American male students. The number of African American males who enter teaching is greatly impacted by the number of African American men who do not complete high school (Gordon, 1994; Brown \& Butty, 1999; Vegas, Murnane \& Willett, 2001) creating a void in the teaching workforce due to the lack of candidates pursuing education. The relationship between African American students and African American male teachers is symbiotic. The number of African American males who pursue teaching is influenced by the number of African American males who attend college, which is also influenced by the number of African American males who graduate from high school (Brown \& Butty, 1999).

African American male students not only experience a number of different challenges while in school, but also confront societal issues along the road to early adulthood (Smith, Hung, \& Franklin, 2011). Studies have proliferated over the last 20 years as scholars have attempted to identify those factors that have discouraged African American men from pursuing a teaching career. One of the earliest empirical qualitative studies conducted with 140 teachers of color in Ohio, Washington State, and California revealed reasons why current educators of color believe that students of color would not choose education as a career path (Gordon, 1994). Gordon (1994) conducted semistructured interviews with the participants in this study and found that lack of adequate educational preparation, negative experiences in schools, dealing with teachers not prepared for diversity, higher rates of discipline, lack of role models and support in college, low pay, and lack of prestige as some of the contributing factors to a lack of presence in the field of education. 
Other societal issues confronting minorities have also been exposed. Blake, Perez and Darensbourg (2010) reported on the staggering statistics of African American males in the prison system. These scholars noted that while $35 \%$ of state and federal male prisoners in the United States were African American, the total population of African Americans in the United States in 2006 was only 12.4\%. Furthermore, 52\% of African American males who did not complete high school had been incarcerated at least once by the time they were 30 years of age (Blake et al., 2010). Their study, of how school-based mental health specialists may provide African American males with the support needed to reduce the instances of exclusionary discipline practices may provide schools and districts with insight on how to combat adverse outcomes for African American males while in school (Blake et al., 2010).

Even before African American males enter into the plight of the penal system, the school system sets this group of students up for failure (Bianco, Leech \& Viesca 2011). Young black boys in school face harsher discipline factors, are more likely to be taught by unprepared teachers, are more likely to be referred to special education (Blake et al., 2010; Grant, 1992; Losen \& Orfield, 2002), and receive more diagnosis as emotionally disturbed (Crothers, 2009; Ferri \& Connor, 2005). Furthermore, African American male students are suspended from school two to three times more often than other students (Blake et al., 2010). These situational factors early on in their education lead to a sense of hopelessness and disenchantment as it relates to school and are early barriers leading these young men away from the educational sector (Bianco et al., 2011; Blake et al., 2010; Gordon, 1994; Graham \& Erwin, 2011). 
As students learn to overcome the obstacles present through their K-12 experience and develop an interest in education as a profession, deterrents for African American males remain in the form of testing requirements. Scholars Kellow and Jones (2008) conducted a quantitative experimental design to determine whether African American high school freshmen students experience stereotype threat when taking a high stakes test as a predictor of success. Both groups of students (White and African American) were told that their performance would be predictive of their performance on a statewidestandardized test. White students scored statistically higher than the African American students (Kellow \& Jones, 2008). The study concluded that African American students expected to be stereotyped based on their ethnicity and hence, "African Americans are at a disadvantage when their knowledge and skills are measured using a high stakes test" (Kellow \& Jones, 2008, p. 116).

Research in later years has substantiated earlier claims that African Americans perform academically lower on standardized testing and this holds true for testing related to the licensure of teacher candidates. In a qualitative study conducted by Dinkins and Thomas (2016), the experiences and perspectives of 10 African American students at a predominantly White institution were examined to determine why students persisted or discontinued in their teacher preparation programs. One of the main barriers found in this study was the academic requirements needed for licensure. States like Kentucky have raised their required grade point average (GPA) from a 2.5 to a 2.75 in order or stay in the teacher preparation program and many states have also started requiring the passing of the Praxis I exam of basic skills to stay in the teacher program (Dinkins \& Thomas, 2016). Historically, African American teacher candidates have passing rates 35\% lower 
than their White counterparts, and teacher licensure exams like the Praxis II negatively affect African American teacher candidates (Dinkins \& Thomas, 2016). These standardized tests provide a significant barrier for African American males who may have a desire to pursue education but are not adequately prepared to meet the demands of the testing requirements (Dinkins \& Thomas, 2016).

Previous qualitative studies related to teacher licensure and standardized testing (Ingersoll \& May, 2011; Madkins, 2011; Solano-Flores \& Nelson-Barber, 2001; Szecsi \& Spillman, 2012) have confirmed Dinkins \& Thomas's 2016 recent study detailing the impact testing and academics have on the outlook of teaching jobs for African American candidates. Many critics of standardized tests have argued that exams like the Praxis do not measure teacher effectiveness or teacher preparedness because the majority of these tests are comprised of multiple-choice questions (Madkins, 2011). Cultural and social norms may affect how African Americans or other minority groups understand and interpret the wording of test questions that may be present on tests such as the Praxis (Solano-Flores \& Nelson-Barber, 2001). A thorough search was conducted to find more recent empirical articles related to the educational testing barriers facing African Americans, but no recent studies have been conducted that specifically address the impact of testing requirements on African American teacher candidates. It is possible that universities and state educational boards are finding alternative approaches to teacher licensure and if that is the case, additional research is needed in the field of alternative teacher certification.

As testing and other academic inhibitors are recognized as barriers, other societal roadblocks preventing African American males from entering the teaching field include 
gender stereotypes and racism (Gordon, 1994). Teaching is often seen as women's work and as recently as the 1960 s, men were not supposed to take on the role of a teacher as demonstrated by Sexton (1969) when he said, "putting a man, any man, in place of women in school will not do. A man who is less than a man can be more damaging to boys than domineering mothers" (p. 29-30). While numerous studies have been conducted related to the male classroom teacher, much of the focus has been on the role of elementary male teachers (Clifford, 1989; Coulter \& McNay, 1993; Francis \& Skelton, 2001; Gold \& Reis, 1982; Martino \& Berrill, 2003). These studies have found that males face societal barriers from parents, colleagues, and even students because teaching has predominantly been seen as a woman's responsibility.

Men in education fear being perceived as homosexual, bisexual, or transgendered because teaching is seen as a nurturing role and it is less likely for heterosexual men to take on this role as strong masculine beings (Rice \& Goessling, 2005; Wiest, 2003). These perceived stereotypes are preventing males from entering the teaching profession, especially in the field of elementary education (Wiest, 2003). As recent as 2018, scholars Cruickshank, Pederson, Cooley, and Hill expanded upon previous literature pertaining to the gender-related challenges faced by male teachers by creating a scale that quantified the challenges faced by male-primary teachers. Their participants consisted of 53 male primary teachers in Australia who completed a survey related to the challenges of teaching (Cruickshank et al., 2018). The results were consistent with earlier studies in that most of the participants cited that physical contact, workload, and isolation were the main factors contributing to the challenges faced by male teachers (Cruickshank et al., 2018). 
Although some of the studies previously mentioned recounted experiences of males at the high school level, the preponderance of information was related to males at the elementary level. More research would be necessary for deterrents related to male teachers at the high school level, specifically African American males. As males are supposed to be strong figures of masculinity (Rice \& Goessling, 2005), negative stereotypes of males in the teaching profession may serve as deterrents to entering the field.

One of the most highly recognized reasons that African American males do not pursue education as a career choice is the potential for racism (Lynn, 2002). As far back as the 1930s, scholars have recognized the apparent racism facing African American children and African American teachers even before segregation (De Bois, 1935). Many scholars throughout the decades have recounted stories of cultural differences and racism experienced by African American students and African American teachers (Brown \& Butty, 1999; Cooper \& Jordan, 2003; Vavrus \& Cole, 2002).

In a qualitative study with 22 Black male high school students in grades 11 and 12 who enrolled in a pre-collegiate Intro to Urban Education pathway course, Goings and Bianco (2016) sought to determine the factors that attract and detract high school African American males to the teaching profession. After interviews were conducted and transcribed, the researchers found one of the main themes being stereotypes and microaggressions as barriers to entering the teaching field (Goings \& Bianco, 2016). Students perceived that they were singled out or misrepresented by white teachers causing them to have a negative interpretation of what teachers were and the students questioned why they would want to be one (Goings \& Bianco, 2016). The information 
found in this study is consistent with other studies examining racial and cultural differences in schools.

Sue (2004) contends that racism and microaggressions are symptomatic of institutional racism termed 'ethnocentric monoculturalism'. This term encapsulates the hidden view that keeps European Americans from recognizing the various beliefs, values, and assumptions that they impose on other races (Sue, 2004). African American students and potential future teachers witness and experience these instances of ethnocentric monoculturalism and thus, do not see themselves as a part of the future of educational professionals (Brown, 2014). As African Americans are choosing to become educators, instances of racism and microaggressions persist. This phenomenon will be discussed in a later section of this literature review. These occurrences of racism continue to be witnessed by African American students and serve as a deterrent to becoming future educators (Jay, 2009).

In summary, negative experiences in school as a student, lack of academic preparation to meet testing requirements, gender role perceptions, male stereotypes, and institutional racism contribute to the low number of African American males pursuing teaching as a profession. Starting with grade school, young black men are often targets of a system that devalues African American boys and focuses on the negative aspects of their lives. As these young men transition into high school and adulthood, they may be plagued with the same types of experiences they endured as a child and so it is not surprising that these African American adult males would not place themselves into a career that has consistently devalued them. Those individuals that do choose to pursue education as a career do so often despite the experiences they have had growing up. The 
reasons African American men choose to become educators will be explored with more depth in the upcoming section.

\section{Motivations for Entering the Teaching Profession}

During the 1950s, approximately half of African American professionals were teachers (Cole, 1986). Since public schools were segregated and African American children needed to be educated, schools for African American children needed African American teachers (Cole, 1986). Teaching was seen as a prestigious career within the African American community during segregation and these individuals were motivated to teach because of the impact they were having on future generations of African Americans (Hudson \& Holmes, 1994). Once desegregation was enacted in the historic Brown versus Board of Education of Topeka, Kansas case in 1954, however, African American teachers began to leave the profession or be eliminated from the profession by White females who were seen as more capable of teaching both White and African American children (Cole, 1986). Since schools have been integrated, there has been a dramatic drop in the number of individuals pursuing education as a career choice, but those who remain dedicated to the profession share similar motivations for choosing education (Hudson \& Holmes, 1994).

With school systems struggling to attract African American males, researchers focused attention on what factors influence African American men to pursue teaching as a career choice. One of the earliest studies conducted to examine this phenomenon found that those who entered teaching did so to address systemic problems (King, 1993). In her study of 41 African American men who attended the University of Illinois at Chicago

during the 1989-90 academic term, King (1993) investigated why this cohort was seeking 
a teaching career. King's study suggested that the most influential factors leading to the teaching profession were lack of role models for youth, the need for minority teachers, the poor conditions of minority communities, and their interest in a service occupation (King, 1993).

Although the previous research was conducted 25 years ago, recent studies continue to support many of the themes uncovered in King's (1993) seminal work. For example, in their study of 140 African American males in a school district outside of Washington, D.C. between the years of 1993 and 1998, Brown and Butty (1999) found that African American males who were able to navigate college and teacher competency testing were motivated by the desire to impart knowledge to others and work with young people. This desire to impart knowledge to others, educate students, and work with young people has also been substantiated in later empirical studies involving African American teachers and their motivations for teaching (James, 2002; Lewis, 2007; Chin \& Young, 2007). These types of intrinsic motivators appear as common reasons why all teachers, regardless of race, choose teaching as a profession (Hammond, 2002; Manuel \& Hughes, 2006; Priyadharshini \& Robinson-Pant, 2003).

The belief that African Americans could be change agents or help promote social justice in the lives of Black students has also been linked to reasons for African American males opting into the teaching profession (Dinkins \& Thomas, 2016; Lewis, 2007; Martino \& Rezai-Rashti, 2010). Lynn (2002) conducted a study with 36 African American male teachers in three schools in the Los Angeles Public school district to determine their perceptions of race, why they chose teaching, and how their race affects their role as a teacher. The majority of the men in this study found themselves to be 
change agents and to possess the ability to change the lives of African American children, especially in disadvantaged communities (Lynn, 2002). These men believed that as agents of change, they could potentially influence the trajectory of a student's life by helping them focus on transforming their perspectives on who they are, how they behave in society, and how they are perceived in the community. The participants also saw themselves as role models who needed to mentor young Black males because of the plight of Black males in the United States (Lynn, 2002).

This desire to change the communities in which their students from disadvantaged backgrounds reside has surfaced across multiple empirical studies conducted over the last 20 years. In his qualitative study with 10 African American males, Brown (2012) interviewed his participants to provide a revised theorization about the discourse surrounding the practice of education as well as the factors related to the notion of being a role model and community changer. This research found that African American males seek to influence change in the communities in which they live by educating the individuals that reside within the community to change the circumstances that bring about hardships and disadvantages for them (Brown, 2012). Other qualitative researchers have corroborated the work of Brown, by placing a heavy emphasis on community building and change as a determining factor for why African American males choose education (Dinkins \& Thomas, 2016; Dixson \& Dingus, 2008).

The empirical literature suggests that the motivational factors for African American males choosing education are primarily motivated by altruism. They desire to be role models for Black boys, change agents for disadvantaged students, support the communities in which they live, and promote social justice and equity among their 
students. Research that is more recent may be necessary to determine if motivations have shifted with the changes in society with respect to job market pressures and navigating life in the $21^{\text {st }}$ century.

Even if African American males can bypass the barriers of their childhood and pursue their altruistic calling to teach, give back to the community, and advance the next generation, these men face more obstacles. Once African American men enter the classroom they are confronted with a different set of barriers they must navigate to feel validated in the career choice they have made. These experiences in the classroom setting are described in more detail in the sections to come.

\section{Barriers during Teaching}

Upon securing their teaching positions, African American males are still confronted with a series of obstacles that can be so detrimental to their careers that they often choose to leave the education profession and seek employment elsewhere (Jay, 2009). Many of the barriers these men face present themselves in the form of racism that may be overt or may be reflected in microaggressions (Jay, 2009). These microaggressions are more subtle acts that may be verbal or behavioral that communicate hostility toward people of color (Sue et al., 2007). Racism surfaces within African American males' careers in various ways, including feelings of isolation and ostracism (Bristol, 2018; Ladson-Billings \& Tate, 1995; Mabokela \& Madsen, 2003; Morris, 2004; Tate, 1997), typecasting and prescribed roles within the school setting (Bristol \& Mentor, 2018; Brown, 2012, Bryan \& Bowder, 2013; Lewis, 2007; Milner, 2012), and an overall lack of confidence and trust in their abilities (Bryan \& Ford, 2014; Decuir-Gunby \& Gunby, 2016; Jay, 2009; Milner, 2007; Pabon, 2016). These instances of racism and 
microaggressions are cause for alarm because African Americans are leaving the profession at alarming rates (Jay, 2009).

\section{Isolation}

Research involving the isolation and ostracism of African American teachers has been conducted since the early 1990s, as the decline in African American teachers became an urgent issue facing educational institutions (Bristol, 2018; Ladson-Billings \& Tate, 1995; Morris, 2004; Tate, 1997). The most recent data available related to teacher turnover specifically related to isolation occurred in the year 2000. At that time, 540,000 teachers moved to other schools or left the profession due to isolation (Heider, 2005). While that number is reflective of all races, genders, and not African American males in general, some studies indicate African American males perceive themselves at a greater disadvantage as it pertains to isolation, as only $2.0 \%$ of the nation's teachers are African American males (Milner, 2018). When these individuals are placed in an environment where they are sometimes the only minority in the school, feelings of isolation and ostracism emerge. The outcome is the marginalization of these individuals because they do not have a cohort with which to feel supported (Lynn, 2006).

In a recent qualitative study conducted by Bristol (2018), the experiences of African American male teachers in one urban school district in Boston, Massachusetts were explored using the Black Male Teacher Environment Survey (BMTES). The BMTES survey, completed by 86 African American males, provided data that enabled the researchers to create groupings based on how individuals experienced the organization they worked within (Bristol, 2018). This study placed a heavy emphasis on isolation and the phenomenon these individuals may face as a "loner" (only one African 
American male on staff) or a "grouper" (four or more African American males on staff) (Bristol, 2018). This study found that loners, more so than groupers, experienced a lack of autonomy and decision making power that made it difficult for these teachers of color to feel like they were part of a team or held any type of power concerning the academic decisions being made at their school (Bristol, 2018). Overall, Bristol (2018) discovered that an increased number of Black male teachers on the faculty was associated with a greater desire to remain at the school because they felt a sense of community with same race peers.

Bristol's (2018) research also found loners, more so than groupers, perceived that their White colleagues were afraid of them because of their race and did not know how to interact with them as the only African American male on the teaching staff, thus creating an atmosphere of isolation. The isolation that loner African American male teachers experienced rendered them more likely to want to leave their schools versus grouper males because of the effects isolation paired with the strained relationships they experienced with colleagues had on their daily lives as a teacher (Bristol, 2018). This loner phenomenon can be seen throughout similar studies related to teacher isolation (Ladson-Billings \& Tate, 1995; Morris, 2004; Tate, 1997).

Even before the Bristol study in 2018, researchers were investigating the impact of isolation on African American males in education. Mabokela and Madsen (2003) used the terms 'outsider' and 'insider' to describe the experiences of 14 African American teachers, seven of which were males. The participants were seen as insiders with respect to the information they could provide about African American related issues, however, they were treated as outsiders whose narrowly defined expertise as an African American 
resulted in isolation and the inability to attain any type of social power within the school (Mabokela \& Madsen, 2003). The males in this study perceived tension with their European American counterparts, especially in dealing with issues related to the educational needs of African American students and their parents (Mabokela \& Madsen, 2003). By only addressing multicultural issues within the school, the male individuals in this study felt the boundaries of being treated like an outsider because they were not able to openly share with their colleagues on issues not dealing with race and culture (Mabokela \& Madsen, 2003). The researchers in this study argue that the ability to ascertain racism and then be able to confront it takes a substantial amount of inner strength and interpersonal skills for teachers of color in the school setting (Mabokela \& Madsen, 2003). Establishing a clear organizational structure and developing an environment to foster group and intergroup differences may be beneficial for teachers of color to feel that their voices are heard and appreciated (Cheng, 1993; Hoy, 1990; Mabokela \& Madsen, 2003).

When examining the number of African American male teachers in public education, those individuals who chose to remain in education find themselves in the minority. In the presence of minority workers (African Americans), majority workers (European Americans) create heightened boundaries where the minority workers are seen as a threat to the commonality of the group, resulting in the development of the outsider group (Kanter, 1977). This form of ostracism, although not always a direct form of racism, may threaten the workplace environment of African American teachers and as a result, become a daily barrier that these individuals must endure (Jay, 2009). 


\section{Typecasting}

When African American males are expected, based on their race, to consistently assume roles such as disciplinarian, coach, or mentor to only African American students, Bristol and Mentor (2018) argue this typecasting is a form of macroaggression. These typecast roles often take these individuals away from the responsibilities prescribed by their college degrees, burdening them to perform unappealing duties (Brown, 2012). Numerous empirical studies have been conducted in recent years detailing the barriers African American males must withstand daily by being typecast as disciplinarians first and teachers second (Bristol \& Mentor, 2018; Brockenbrough, 2015; Bryan \& Bowder, 2013; Howard, Flennaugh \& Terry, 2012; Lewis, 2007; Martino, 2015; Martino \& RezaiRashti, 2010; Milner, 2012; Pabon, 2016). The methodological approaches used in these studies has been vast, with scholars providing data that identifies perceptions of African American male teachers on typecasting as well as outcomes from typecasting on their ability to succeed and thrive in the workplace.

In recent work by scholars Bristol and Mentor (2018), African American male teachers suggested that their colleagues and administrators place them in positions to serve as de facto disciplinarians where they are responsible for managing student behavior within their schools. In their qualitative study of 27 African American men in a large, northeastern school district, they found that African American male teachers reported that their colleagues were more likely to seek their help with matters related to student behavior rather than asking for help with curriculum design (Bristol \& Mentor, 2018). Bristol and Mentor (2018) posit that these unnecessary added responsibilities led to stress and early burnout for these individuals (Bristol \& Mentor, 2018). 
In Brown's (2012) study, the African American male teachers perceived that they were expected to be physically intimidating and use their physical stature as a way of intimidating Black boys in the classroom. According to Brown (2012) these men "are reduced and essentialized through explicit and subtle discourses of deviance and difference" (p. 308). Furthermore, he argues that school officials, parents, and colleagues typecast African American males and assume that their ability to teach African American male students derives from their being Black and not from their pedagogical ability (Brown, 2012).

Researchers have found that the age level of the students with which African American males work does not appear to differentiate the roles that they are asked to fulfill or the perceptions of these individuals (Martion \& Rezai-Rashti, 2010). Scholars Martion \& Rezai-Rashti (2010) argue that even at the elementary level, African American male teachers are perceived as rappers, sports stars, coaches, and these teachers are often sent the troublesome boys to manage because they are male and Black. Bryan and Browder (2013) concur with this argument and suggest it becomes very difficult for African American males to see the impact they are trying to make in students' lives, when they are viewed as coaches and disciplinary teachers, rather than academic and scholarly individuals. Pabon (2016) encapsulated these stereotypical expectations by suggesting that these teachers are expected to be Black Supermen. Scholars (Brockenbrough, 2015; Brown, 2012; Morris \& Morris, 2013; Pabon, 2016) have also pointed to the unintended outcomes that often result from typecasting African American males into authoritarian teachers. Among these consequences are animosity from students as well as strained relationships with colleagues and leaders because they are perceived 
as too dominant and unapproachable, even though this was the role they were asked to play (Brokenbrough, 2015).

Typecasting as found within the literature, although an indirect form of racism experienced by African American male teachers, may provide a daily barrier that these men must overcome to focus on their role as a teacher. While being a role model or change agent is important for these men as evidenced by their motivations for choosing teaching, serving as a student's disciplinarian was not one of the motivators found within the literature. By placing African American male teachers in stereotypical roles, a lack of trust in their abilities emerges as another form of racism they may experience on a continual basis (Bryan \& Ford, 2014).

\section{Lack of Trust}

As African American males enter the classroom they are confronted with forms of racism and microaggressions that present themselves in the apparent lack of trust and confidence in their abilities as a teacher (Milner, 2012). African American men must overcome the negative perceptions formed about them and work harder to garner the trust and respect of colleagues, parents, and students (Milner, 2012). In numerous qualitative studies conducted over the last 20 years, racism is exposed in the school setting when individuals question an African American male teacher's teaching practices, their capacity to teach high-quality content, and their ability to garner trust (Bryan \& Browder, 2013; Bryan \& Ford, 2014; Jay, 2009; Milner, 2012; Pabon, 2016; Smith, Hung \& Franklin, 2011).

In Bryan and Browder's (2013) qualitative study, the lived experiences of an African American male kindergarten teacher were explored before, during, and after his 
pre-service experiences and later on in his teaching career. One of the barriers investigated in this study were the microaggressions this individual experienced in the form of direct racial comments and non-verbal body language from parents and other staff who felt that he did not belong in the profession because of the color of his skin Bryan \& Browder, 2013). The study recounted experiences of the teacher being greeted by parents on the first day of school and being questioned if he was the actual teacher and being interrogated about his abilities to teach their children (Bryan \& Browder, 2013). The participant believed that the parent questioned his efficacy because he is a Black male and the researchers of this study introduce this form of macroaggression as the ascription of intelligence, which assigns intelligence or ability to a person of color based on their race (Bryan \& Browder, 2013; Pittman, 2012; Sue et al., 2008).

This lack of trust extends to various educational programs within the school, including Gifted Education (Bryan \& Ford, 2014). Historically, African American students are not enrolled in gifted education as only $4 \%$ of the gifted population is comprised of African American males (Bryan \& Ford, 2014). Bryan and Ford (2014) maintain that the criteria for African American students to enter gifted programs is often culturally biased and insensitive. This bias often extends to African American males as these individuals are viewed as intellectually inferior and physically threatening. Further, these scholars argue that administrators often discourage African American male teachers from teaching in gifted programs because of the pre-conceived notion that these teachers lack the capability of teaching gifted students (Bryan \& Ford, 2014).

African American males, although educated by many of the same college systems as their white counterparts are seen as inferior and feel additional levels of pressure to 
prove themselves to their colleagues, parents and students (Jay, 2009). Microaggressions present themselves when individuals perceive African American males as unintelligent or incapable of performing their duties in the workplace (Smith et al., 2011). When an African American male's teaching practices are questioned, the outcome results in the creation of unnecessary stresses that may eventually lead to teacher burnout (Jay, 2009). A lack of trust and confidence in African American teachers that are hired to perform a job can prove to compound the overall negative impressions that these individuals battle everyday (Milner, 2012).

\section{Summary of Barriers}

As evidenced by the empirical studies discussed in this section, racism and microaggressions are prominent barriers that African American men must endure once they enter the classroom. They must not only navigate these barriers, but at times must overcompensate in order to be seen as an intellectual being, capable of teaching not only African American children but also all children. As evidenced by the research, African American men often feel a sense of isolation and often experience racism and microaggressions from parents, students, and even colleagues as they are typecast in roles they had not prepared for and must prove their worth as a teacher in an environment that believes that they are inferior. These factors of racism play a role in deterring African American males from remaining in the education profession and although these individuals desire to fulfill their calling as an altruistic leader in the classroom, recruitment and retention efforts will be greatly impacted if racism and microaggressions are not addressed (Jay, 2009). 


\section{Recruitment and Retention Efforts}

\section{Recruitment}

Efforts to recruit more minority teachers, specifically African American males are increasing. While most of these initiatives are taking place at the state level, on the national front in 2010, under the Obama administration, the United States Department of Education introduced the Teach Campaign, with the goal of increasing African American male teachers by $5 \%$ by the year 2020 (Underwood, Smith, Johnson-Lutz, Taylor \& Roberts, 2019). The Secretary of Education at that time, Arnie Duncan, challenged Historically Black Colleges and Universities (HBCUs) like Morehouse and Howard to address the widening gap in African American male teachers (Underwood et al., 2019). Unfortunately, since the Obama administration ended, there have not been any new national initiatives to recruit African American males like that of the Teach Campaign. What the Teach Campaign did do however, was encourage more state and local initiatives aimed at diversifying the educational workforce and recruiting more African American males into the classroom (Underwood et al., 2019).

Numerous states have created policies surrounding minority teacher recruitment. In Illinois, Senate Bill 1739, for example, seeks to allow minority teacher scholarship opportunities for pursuing additional certifications or Master's Degrees (Education Commission of the States, 2019). In Connecticut, Senate Bill 1098 requires the state department of education to discuss and develop strategies to increase minority teacher recruitment and retention (Education Commission of the States, 2019).

Furthermore, on a macro scale, The Council for Chief State School Officers created a yearlong program aimed at providing nine states with access to experts to assist 
in creating diversity in their teacher workforces (Camera, 2018). Mississippi set a goal through this program to increase teachers of color by $25 \%$, while states like Massachusetts focused on recruiting teachers of color for their teacher fellowship program by identifying minority students in high school who could fill the teaching pipeline. The goal of the program created by the Council for Chief State School Officers was to help these potential future educators by providing mentors, college preparation courses, financial incentives, and guaranteed teaching positions (Camera, 2018). Washington State operates the Martinez Fellowship, a program designed to support minority teachers by providing scholarships, career coaching, and professional development aimed to retain the teachers of color they have while also recruiting more potential teacher candidates (Camera, 2018).

The efforts cited above suggest states are recognizing the value of having more minority teachers in their schools, but they understand the challenges of fostering true recruitment initiatives (Ingersoll \& May, 2011). While efforts have been made at the state level to recruit more minority teachers, less attention has been given to the recruitment of African American males specifically. Some colleges and universities across the United States have begun to tackle the minority teacher shortage while a few have attempted to address the lack of African American males specifically.

Scholars Valle-Riestra, Shealey, and Cramer (2011) conducted research at a Florida University active in the recruitment of minority teachers for the Special Education field. These scholars surveyed participants in the program in an effort to determine the reasons these students stayed in the program and later pursued employment as a special education teacher. Based on findings from their study, these researchers 
concluded that opportunities for mentoring, financial support, community building, engagement in meaningful and relevant field experiences, and professional development were instrumental in the recruitment of a diverse teacher candidate pool (Valle-Riestra et al., 2011).

As evidence by a search of the literature, many other colleges and universities are creating programs and incentives aimed at the recruitment of minority teacher candidates similar to the one at the Florida University (Bireda, \& Chait, 2011; Bulger, Jones, Taliaferro \& Wayda, 2015; Ingersoll \& May, 2016; Szecsi \& Spillman, 2012; Villegas, Strom \& Lucas, 2012). The research suggests that providing financial incentives, a community-based network, mentoring, and strategic professional development are efforts being used to recruit a more diverse population into college and university teacher preparation programs. College and university programs aimed at specifically addressing the gap in the African American male teacher workforce also exist, but in limited numbers (Pabon, Anderson \& Kharem, 2011).

Jones, Holton and Joseph (2019) profiled Clemson University's Call Me Mister (CMM) program, which seeks to recruit, retain, and develop African American male teachers at the elementary and middle school levels. The program was originally developed with three historically Black colleges and universities (HCBUs) to address the shortage of African American male teachers in the K-8 public education sector. The CMM program is divided into five components that include ambassadorship, brother's keeper, personal growth, teacher efficacy, and servant leadership (Jones et al., 2019). Prospective CMM teachers must apply to the program and once they are accepted, they are immersed in an atmosphere where they live in a community, are given the 
opportunity to develop leadership skills and are mentored, experience internships and workforce development, and become active in the community. Since its inception, over $90 \%$ of the program's 221 graduates have remained teachers, school administrators or work at the university level (Jones et al., 2019).

A criteria search found five other similar university programs aimed at the recruitment of African American males specifically. The overarching theme of programs such as Teach Tomorrow in Oakland, The Griot Program, The Ready to Teach Program, The Urban Community Teachers Project, and The Black Male Initiative Project were initiatives aimed at providing scholarships, workshops, test preparation, mentorship, field experiences, and most importantly homogeneous racial interactions within a cohort or community-based setting (Bryan, Johnson \& Williams, 2016; Irvine \& Fenwick, 2011; Okezie, 2018; Pabon, Anderson \& Kharem, 2011; Underwood et al., 2019). The majority of these programs were developed within HBCUs with the exception of the Griot Program. Historically Black Colleges and Universities are extremely successful with $50 \%$ of the African American teaching workforce graduating from an HBCU (Underwood et al., 2019). All of the programs listed above have shown high success rates in producing African American male teachers, but information regarding retention of teachers after college and later on into their careers as educators is limited.

The outcome of the recruitment efforts across states and colleges has resulted in a slight increase in the number of African American students attending colleges and universities from $11.7 \%$ in 2000 to $13.7 \%$ in 2016 . Many institutions of higher education and school districts across the country believe that increased recruitment efforts are the key to victory, but teacher turnover for African Americans remains higher than that of 
their white counterparts (Ingersoll \& May, 2011a). The battle to increase the number of minority teachers, and specifically African American males, may need to be fought on two fronts: recruitment as well as retention and support in the classroom (Kohli, 2018).

\section{Retention}

Efforts to retain African American male teachers in the classroom have not shown overall success as evidenced by the amount of teacher turnover in this demographic (Underwood et al., 2019). The struggle to populate classrooms with minority teachers is compounded by the struggle to retain these teachers. The United States Department of Education's report on racial diversity in the educator workforce reports turnover among African Americans is approximately seven percentage points higher than that of their white colleagues (UDOE, 2016). A literature search for national school retention efforts for African American males rendered no recent specific programs aimed to retain talent; rather the focus appears to be singularly focused on recruitment.

Literature focusing on retention efforts at the institutional level is more general in nature and is often presented in the form of recommendations. Of the more recent school and district level retention efforts, solutions offered include effective school leadership, mentoring and induction programs, and specific professional development (Bristol, 2018; Carver-Thomas, 2018; Kohli, 2018; Kokka, 2016; Sun, 2018). Lacking in the discussions, however, are details about success rates these efforts have delivered.

Teachers of color are more likely to experience job turnover than their white counterparts (Achinstein, Ogawa \& Sexton, 2010). In a research review of over 70 studies involving the retention of teachers of color, Achinstein et al. (2010) found that school conditions, financial capital/teacher salaries, professional development, 
mentoring, administrative support, and teacher autonomy are all reasons impacting a teacher's decision to stay in the classroom for more than two years (Achinstein et al., 2010). Most of the minority teacher turnover occurs within the first five years of employment and school districts often do not find solutions for many of the barriers mentioned in previous sections (Achinstein et al., 2010). Retention efforts involving race and racism are also not addressed at the institutional level resulting in a loss of minority teachers, especially in hard to staff schools (DeCuir-Gunby \& Gunby, 2016).

The effects of race congruence on teacher retention and job satisfaction is another possible factor to consider in institutional policies regarding minority teacher retention. Grissom and Keiser (2011) sought to determine if same race principals had an effect on teacher retention in the public school sector. Using data from a nationally representative sampling of schools across the United States (equally representative of urban/suburban schools and poverty level), the researchers found that one way to retain teachers of color was to employ administrators of the same race. According to Grissom and Keiser (2011), "For African American teachers who work for African American principals, their satisfaction rating is 0.15 points higher on a four point scale than white teachers who work for an African American principal” (p. 572). African American teachers (males and females) are experiencing higher job satisfaction and are less likely to leave the profession if they are supervised by a African American principal because they experience higher levels of administrative support, greater autonomy, and greater levels of recognition (Grissom \& Kesier, 2011). Allowing for extra supplemental pay for African American educators could also provide financial incentives for retention because extra pay is more readily given to white teachers by white principals than is given to 
African American teachers by white principals (Grissom \& Keiser, 2011). This study however did not address African American males specifically.

While African American males are choosing teaching as a career in greater numbers than they have in the past (Underwood et al., 2019), the literature has shown that the rate of tenure for these individuals is not increasing. Hence, the cycle of turnover is in perpetual motion, hampering any uptick in the total number of African American male teachers. Overall, white teachers remain in education at a greater rate compared to other ethnicities, but the retention rates among all groups remain similar. For comparison, among white, non-Hispanic teachers, 83 percent were still teaching after five years, compared to 80 percent of all other races and ethnicities (Gray \& Taie, 2015). Male teachers also tend to leave the profession at a faster rate than female teachers, with 21 percent of men exiting after the fifth year compared to 15 percent of women (Gray \& Taie, 2015). Overall, financial incentives, mentorship, professional development and teacher autonomy are ways to keep teachers in the classroom, but these incentives have not been focused on African American males specifically. Further, these fixes are likely to be temporary if they are not complemented by targeted interventions to minority retention.

Research studies examining the recruitment and retention of minorities in education largely focus on strategies and programs rather than a philosophical approach to why these individuals initially wanted to become teachers. It is important to explore the decisions or experiences pushing them towards education and what experiences send them away from the classroom. The heart of a person's career choice is what can make all the difference in understanding what it takes to recruit and retain more African 
American males at the high school level. The next section will review the literature surrounding Critical Race Theory (CRT) and illuminate the theoretical lens with which this study was conducted. By examining the theoretical lens of CRT, the reader may be able to understand the perspectives and experiences of African American males and their journey to becoming and remaining educators.

\section{Critical Race Theory}

Developed in the 1970s, Critical Race Theory (CRT) emerged as a way to acknowledge race and how it intersects with racism as a means to combat the daily oppression of racial injustices (Kohli, 2008). CRT focuses attention on the relationships between race, racism, and power (Creswell \& Poth, 2018) and was borne out of a need for people of color to begin discussing race and racism in terms of an ideological approach and not an experiential one (Parker \& Lynn, 2002). One goal of CRT is to address areas of difference such as gender, race, class and any other inequities experienced by the participants or individuals who are being studied (Creswell \& Poth, 2018). In the last 10 years, CRT has been widely adopted in the educational field to help engage with and fight against racism by requiring participation and articulation with the material, structural, and ideological instruments of White supremacy in education (Delgado \& Stefancic, 2017; Kohli, 2009; Ladson-Billings \& Tate, 1995; Ledesma \& Calderón, 2015; Lynn, 2006).

According to Milner (2007), race and racism have become so ingrained in everyday thought that it has started to become normal (Milner, 2007). The CRT frame of work acknowledges how Whiteness has and continues to operate both nationally and globally (Brown, 2014). This Whiteness is evident in knowledge, values, and experiences 
in society and educational settings and within the United States; race has played a leading role in maintaining inequitable societal relationships (Brown, 2014). CRT in education recognizes the role race has occupied in patterning societal arrangements since the founding of the United States of America and provides a lens to understand racism (Brown, 2014). CRT emerged as a response to criticisms of legal studies and now, CRT challenges how the law operates, while valuing the lived experiences of people of color in the analysis of law and society (Brown, 2014). The overall goal of CRT within the context of the educational setting is to uncover how race operates in society and education at both the structural and local levels (Brown, 2014). CRT within education offers a means to understand the way race operates within the context of teacher preparation, teacher recruitment, and teacher retention (Brown, 2014). Schools may be attempting to hire and recruit minority teachers, but these attempts fail to specifically address the negative experiences African American males may have experienced growing up in the educational system, as well as the racism and microaggressions these individuals endure once they do decide to become educators (Lynn, 2002). Critical Race theorists call upon individuals to reflect on the explicit and implicit biases they possess and create policies and avenues to dismantle the inherent racism that might be found not only in the educational realm, but within society as a whole (Milner, 2007). To understand the racism that exists within society and more specifically education, one must understand the tenets associated with CRT.

There are five guiding tenets to CRT: 1) centralizing race and racism with other forms of subordination, 2) challenging dominant ideology, 3) committing to social justice, 4) valuing lived experiences, and 5) using interdisciplinary perspectives like 
sociology and psychology (Kohli, 2008). Each tenet provides deeper understanding of how CRT can be applied to various disciplines such as education. The first tenet focuses on centralizing race and racism by exposing race and racism as endemic and permanent, but also demonstrates how these concepts can be intersected with other forms of subordination such as gender and class, thus compounding levels of racism (Soloranzo \& Bernal, 2001). The second tenet of CRT has been used in the realm of education by challenging dominant ideology and exposing claims of objectivity, color-blindness, race neutrality, and equal opportunity (Soloranzo \& Bernal, 2001). A commitment to social justice within CRT, the third tenet of CRT, offers a transformative response to racial oppression and empowers underrepresented minority groups like African American males by contradicting the oppression and marginalization these individuals face within the educational sector (Soloranzo \& Bernal, 2001). The fourth tenet of CRT offers a framework to recognize that the lived experiences of African American males are critical to understanding the racial subordination that is experienced in the field of education (Soloranzo \& Bernal, 2001). These lived experiences may provide insight as to how to analyze and teach about the racial discrimination experienced by African American males and other minority groups within education. The fifth and final tenet of CRT involves embracing interdisciplinary perspectives as it insists on analyzing race and racism in education by placing them both in an historical and contemporary context and provides justification for use in other disciplines such as sociology and psychology (Soloranzo \& Bernal, 2001). By using one or more of the five tenets of CRT, researchers may be able to offer more informed recommendations to combat and potentially eliminate the marginalization of African American males in the school setting by examining the 
sociology and psychology behind the racism and social interactions they experience. In understanding racism and microaggressions, universities, school districts, and individual schools can develop policies and initiatives at the structural and societal level that will aid in the varying stages of an African American male's educational journey and pursuit of a career in the teaching profession.

CRT has been applied in a host of arenas to explore race and racism including sports and leisure (Hylton, 2005; Hylton, 2008; Long \& Hylton, 2002), public health (Ford \& Airhihenbuwa, 2010; Thomas, Quinn, Butler, Fryer \& Garza, 2011), social work (Constance-Huggins, 2012; Kolivoski, Weaver \& Constance-Huggins, 2014; Razack \& Jeffery, 2002;), and politics (Garcia, 1995; Hutchinson, 1999; Lopez, 2003). With respect to the educational sector, educational scholars seek to explore race and expose the inherent racism experienced by minority groups who seek to establish themselves within the realm of education have adopted CRT (Delgado \& Stefancic, 2017; Gillborn, 2006; Taylor, Gillborn \& Ladson-Billings, 2009). For example, at the university level, Thomas, Dinkins and Hazelwood (2018) conducted a qualitative study that examined the perspectives and experiences of 10 African American students in a teacher preparation program at a predominately White institution. CRT was used as an analytical framework for examining microaggressions within this teacher preparation program and adhered to the first tenet of CRT, which maintained that racism penetrated every aspect of the teacher preparation program. Participants were found to have experienced microaggressions that were perpetuated by peers, professors, or other institutional cultures (Thomas et al., 2018). A search of other literature suggests researchers have found similar situations of CRT in use both directly and indirectly at the university level 
for preservice teachers of color and African American males specifically (Brown, 2014;

Cheruvu, Souto-Manning, Lencl \& Chin-Calubaquib, 2015; Matias, Viesca, Garrison-

Wade, Tandon \& Galindo, 2014; Milner \& Laughter, 2015; Sleeter, 2017).

Once African American males find employment, they often must deal with racism and microaggressions from colleagues, students, and parents. Many find themselves detaching as a way to cope with the stresses of racism and microaggressions and most are negatively impacted because of their environments (DeCuir-Gunby \& Gunby, 2016).

Schools have historically served as entities of Eurocentric hierarchies and so students and teachers of color are often viewed negatively because of the color of their skin (Valencia, 2010; Yosso, 2005). CRT examines this concept of Whiteness and privilege at the school level by valuing the experiences of African American men as it pertains to their interactions with their White colleagues and students as well as the negative perceptions and roles placed upon them by those same individuals (Soloranzo \& Bernal, 2001). As a result of the Whiteness and privilege exposed by CRT, schools will often serve as places of hostility for both students and teachers of color unless school leaders or districts decide to speak up against the institutional racism that is often found in schools (DeCuir-Gunby \& Gunby, 2016).

CRT requires the reader to develop "theories of social transformation wherein knowledge is generated specifically for the purpose of addressing and ameliorating conditions of oppression, poverty, or deprivation" (Solórzano \& Yosso, 2002 p. 36). Using CRT requires one to examine experiences with responses to racism in and out of the school setting as valid forms of data (Solórzano \& Yosso, 2002). According to Solórzano \& Yosso (2002), if theoretical frameworks have been used to silence and 
marginalize people of color, then these same frameworks can also give voice and turn the margins into places of transformative resistance.

As African American males are experiencing racism and microaggressions before and during their teaching careers, researchers are exposing the inequities and suggesting ways to combat these inequalities in order to retain these individuals. Researchers have found that it is important that teachers of color be treated as people of intrinsic worth with the capability to change education rather than a commodity that is only used to improve the test scores of students of color (Lapayese, 2007). Overall, increasing the numbers of teachers of color, strengthening leadership development and networks for teachers of color, and exposing and addressing racism in schools can be ways to address the retention of teachers of color and African American males specifically (Kohli, 2016). The use of CRT as a theoretical perspective helped shape the foundation of this study by exposing potential racism and microaggressions in the lives of African American males in Fayette County Public Schools. The lived experiences of these men may have provided a stronger voice to the tenets surrounding CRT and may have provided evidence on ways to combat the marginalization of these individuals and other individuals of color.

\section{Summary of Chapter II}

African American males desire to be change agents for the students they interact with in the classroom. They have been inspired to change the face of history for many underserved and disadvantaged students in their communities and this is why many of these males are choosing teaching as a profession. Entering the world of education, however, is not an easy task. Barriers such as testing requirements, lack of knowledge, and lack of support face these individuals before they ever enter a classroom. Many are 
not able to overcome these barriers and opt for careers that they perceive to be more lucrative and prestigious. When African American men do become teachers they are often faced with the dilemma of additional roles that they must fulfill, such as disciplinarians or coaches. Feelings of isolation, instances of racism, and microaggressions are real barriers for these men, who often find themselves surrounded by a workforce that does not look like them, both in color and often in gender.

Most African American males grew up having had negative experiences in their own educational journey and thus becoming a teacher is seen as foreign. Many of them may possess the knowledge and skills to become an effective teacher, but the barriers placed before them often deter any hopes of these individuals choosing education as a career. Critical Race Theory served as the theoretical lens through which this research was conducted because racism and microaggressions are at the forefront of the barriers these individuals face on a daily basis. It is important to explore more research related to circumstances of why and how these men become teachers and what keeps them in the classroom or sends them running towards a different career. The upcoming chapter will explore the methodological approach used to determine the situational factors contributing to the motivations, barriers, and experiences of African American males in Fayette County, Kentucky high schools and programs. 


\section{CHAPTER III}

\section{METHOD}

The purpose of Chapter III is to introduce the research methodology for this qualitative study regarding African American males' motivational factors for pursuing education as a career, the barriers they face before and during the pursuit of their chosen field of work, and how might the roles they are asked to play in their schools contribute to their tenure as a teacher. The approach taken in this research study allowed for a deeper understanding of the roles microaggressions and racism may play in the lives of African American teachers and explored whether this affects retention of those teachers. The data collected provided the means to develop thoughts about the motivations of African American males in choosing education as well as what classroom retention efforts were necessary to keep them in the classroom within Fayette County Public Schools in Lexington, Kentucky. Within this chapter, the methodology will be explained, along with the application of critical race theory. Furthermore, a review of study participants, procedures, methods for analysis, and ethical concerns is outlined.

\section{Research Questions}

This study sought to fill a gap in the literature and explore why African American male teachers chose the teaching profession, examine the barriers they face in their profession, the roles they play in the schools or districts, as well as what impact these 
roles have on their decision to remain in the profession. The specific research questions of this study included:

RQ1. Why are African American males pursuing a career in high school education?

RQ 2. What barriers do African American males face before and during their teaching careers?

RQ 3. How do the roles African American males are asked to fulfill contribute to their tenure as a teacher?

\section{Research Design}

The qualitative research design selected for this study was an instrumental case study. In an instrumental case study, the researcher focuses on a particular issue or concern and then selects a case to demonstrate the issue (Creswell \& Poth, 2018). The case that is selected in a case study may be an individual, a small group, or an organization (Creswell \& Poth, 2018). According to Creswell and Poth (2018), a case study explores a real-life issue over time through detailed data collection that may include observations, interviews, documents, or archival reports. A key component to case study work is that it remains bounded, meaning that it has defined and specific parameters such as a timeframe and place (Creswell \& Poth, 2018). A conclusion develops through a case study that contains assertions about the researched topic (Creswell \& Poth, 2018).

Though limited in generalizability, instrumental case studies may be useful to help refine a theory or provide illumination to a complex societal or organizational issue (Baxter \& Jack, 2008). The case plays only a supporting role, as the focus is on the phenomenon under investigation (Baxter \& Jack, 2008)). In this study, investigating what 
led African American male high school teachers into the classroom and what they have experienced in their careers shed light on the broader issue of the shortage of black men in the teaching profession. The theoretical lens guiding this case was Critical Race Theory.

\section{Critical Race Theory}

Researchers Stanfield (1999) and Foster (1994) have described how qualitative research once described different aspects of African American life as filled with issues of participant exploitation by White European American researchers who did not address the power imbalance between researchers and their minority participants. This research study of African American male teachers was important and necessary to address the power balance often seen between researchers and participants of color, but also between participants of color and their everyday environments. For this study, the educational work environment of African American male high school teachers in Fayette County Kentucky was examined.

CRT aligned with this study of African American male high school teachers because it offered a conceptual framework from which to view how racism affects African American males before and during the pursuit of their educational career. Little to no debate exists that the U.S. education system has struggled with race (LadsonBillings \& Tate, 1995). Racially biased systems of education exist because many individuals carry a skewed view of minority and ethnic groups that are non-white (Kohli, 2008). Teacher education programs that are attempting to recruit teachers of color need to reflect on their thoughts of White cultural superiority and how this may shape their worldviews when trying to recruit minority candidates into their programs (Kohli, 2008). 
Once hired, these individuals may continue to face instances of racism and microaggressions. Hence, the interview questions composed for this research on African American male teachers in the high school system, and throughout the coding process, adopted the CRT lens to highlight underlying themes associated with racism and microaggressions the participants may have experienced in their lives.

\section{The Researcher}

I have worked in education for 15 years and have had extensive experience inside the classroom as a high school teacher for seven years and outside the classroom as an administrator for the last eight years. As a minority male, I have had experiences that many researchers will not possess as it pertains to questioning other minority males about their educational journey and I have been trained with the necessary skills to interview the research participants and ask questions that would elicit a meaningful response.

Before beginning the research process, I needed to pose both racially and culturally grounded questions to myself so that the questions raised awareness related to the consciousness both known and unknown, unanticipated issues, perspectives, epistemologies, and the varying positions of this research topic (Milner, 2007).

\section{Data Sources}

For this purpose of this study, data was collected from formal interviews, with all procedures being explained in this section. This data source helped to inform the research study as well as creating credibility and transferability of the research (Korstjens \& Moser, 2018). 


\section{Study Participants}

The research participants in this study were current African American male educators in Fayette County. Their experiences navigating their decisions to teach and later the barriers they faced in continuing to teach are the topics that were highly valued in this research. Through their experiences, readers will be able to identify the implicit and explicit bias and racism these participants have experienced and why they have persevered in pursuing the teaching profession.

The participants were selected based on purposeful sampling. Purposeful sampling was used in the selection of the research participants because the participants needed access to key information within the field of education to identify informationrich content (Suri, 2011). The Human Resources (HR) department for Fayette County Public Schools was contacted by email and a request for a list of all African American male teachers at the high school level, their work-based email address, their years of experience in education, their primary content and/or teaching assignment, and the name of their school was made of the district. The HR department was assured in a letter that the list was intended for research purposes only and the participant's names would not be disclosed in the publication of the study. After the list was finalized, the potential participants were contacted via email to set up interview dates and times.

To facilitate an easier understanding of the dialogue process when the interviews were taking place, all participants needed to be fluent in the English language but English did not have to be their native language. Translators may not have been available for any language that may have required a translation. While the subject group for this study included African American educators at the high school level (grades 9-12), there were 
no criteria as to the subject taught. The study benefited from a variety of content areas and disciplines, and study participants spanned a range of experience in education. An informed consent form (See Appendix A) was given to each identified potential participant for this study. Though the final number of participants in this study was to be determined by saturation, due to the limited number of African American male high school teachers in Fayette County the highest number was unlikely to exceed 25. Overall, 20 potential participants who met the criteria of classroom teacher, male, and African American were identified within the Fayette County school system. The 20 individuals were emailed and asked to participate in this study. Ten of the participants agreed to participate (50\%), nine of the potential participants (45\%) did not respond to the invitations, and one potential participant $(5 \%)$ declined to participate. The active participants varied in years of experience teaching in Fayette County Public Schools from two years to 18 years. All participants had taught for more than three years total, with some of those years of experience being outside the Fayette County school district. The participants ranged in age from early twenties to late sixties. The specific ages of the participants will not be discussed in order to provide anonymity for the participants. All academic core content courses of Math, Science, English, and Social Studies were represented in the sample, along with elective and special education teachers. Four of the six large traditional high schools were represented and two of the seven specialized high school programs for approximately $46 \%$ of the high school programs in Fayette County. 


\section{Data Collection}

\section{Semi-Structured Interviews}

The 10 interviews with the African American male high school teachers served as the data source for this research. Interviews were conducted virtually via Zoom at times convenient to the interviewees. The interviews did not exceed one hour, and each interview took place in a single session and each interview was recorded. Two recording devices were used to ensure the reliability of the recording in case one device malfunctioned. All interviews were conducted only after obtaining the written and verbal consent of each participant.

For this study, a semi-structured interview process was used to collect data. The interview consisted of semi-structured questions (See Appendix B) and allowed for more open-ended questions based on the responses of the participants, especially if clarification was sought for any question. A semi-structured interview has its basis in human conversation, and it allows the interviewer to modify the style, pace, and ordering of questions so that the most beneficial information is received from the participant $(\mathrm{Qu} \&$ Dumay, 2011). A semi-structured interview also enabled the interviewees to respond to the questioning in the way they felt most comfortable and on their terms concerning how they think and speak (Qu \& Dumay, 2011).

After each interview was complete, journaling and memo notes occurred to capture any initial thoughts and reactions to the interview process. After every three interviews, the batch of three was coded manually and reviewed for emergent themes. The final interview was coded by itself as it was completed approximately three weeks after the ninth interview was complete. 


\section{Procedures Followed for Study}

Before engaging the study participants, approval from the Institutional Review Board (IRB) was sought from the University of Louisville. Approval was also obtained from the Fayette County Public School Office of Data and Accountability. Once approval was given from both entities, the research participants were emailed using the text from the Email to Potential Participants (see Appendix C). After participants responded via email to the initial interest email, a follow-up phone call was made to each willing participant to answer any questions they had and to clarify the interview and data collection process. Due to the worldwide pandemic, the interviews took place virtually. Following the interview transcription, the transcription text was sent to each participant to review for accuracy. The interviewee was asked if they would like to add any clarifying thoughts related to the transcription upon reflection of the text. All 10 participants granted approval of the transcripts after the first initial review.

\section{Data Analysis}

Coding in qualitative research, "Is most often a word or short phrase that symbolically assigns a summative, salient, essence-capturing, and/or evocative attribute for a portion of language-based or visual data" (Saldaña, 2016, p. 4). Coding is divided into two cycles: first-order coding methods are the processes that occur during the initial coding of the collected data and second-order coding methods are more advanced ways to reorganize and reanalyze data that was coded during the first cycle (Saldaña, 2016). For this instrumental case study, a blend of deductive coding and inductive coding occurred depending on which stage, first-order or second-order, took place. Initially, deductive 
coding was implemented with a codebook developed before data collection because of the familiarity of the research topic (Christians \& Carey, 1989).

All 10 interviews were coded manually during the first-order coding process by using pattern matching based on deductive analysis. A priori codes were developed that aided the researcher in matching patterns found within the interview data to original predictions related to African American males in education (Yin, 2018). The interviews were analyzed in batches of three participants, which allowed for analysis time and reflection before moving on to additional participants in the study. Codes and emerging themes had been previously created prior to the interview process and once the interviews were complete, emerging themed patterns were compared to the original list of codes and themes.

Transcripts were also uploaded into computer software, NVivo 12, for further data analysis. Each interview was manually coded within the computer software and then compared to the original manual coding completed during the interview process. The ability to code the interviews again for second-order coding, allowed use of an inductive approach and allowed for the discovery of more advanced ways of organizing the data. The second-order coding process focused more on the concepts of racial microaggressions and the climate of the schools where the research participants worked. In Vivo coding was employed throughout this process and used words and phrases from the participants' own words to serve as codes (Miles, Huberman, \& Saldaña, 2014).

As the transcripts were read, responses expressed by participants were examined for emerging themes. A chart was created using a Microsoft Excel Spreadsheet and the participants listed as A, B, C, etc., and continued until the total number of participants 
were represented. There were categories for line, text, first-order coding, and secondorder coding. This spreadsheet was made to organize thoughts and ideas that were central to the research questions paying special attention to the words or phrases that were likely to capture meaning associated with the participant's experiences. (Saldaña, 2016).

\section{First-Order Coding}

First-order coding uses mainly descriptive, low inference codes, which researchers find useful in summarizing data and provides a starting point for higher-order coding to occur later in the second cycle (Elliott, 2018). In this study, based on prior literature having identified motivations and barriers, a codebook was developed before data collection (Christians \& Carey, 1989). For this case study, pattern matching was one of the main analysis techniques that was used to analyze the data collected. Pattern matching compares an empirically based pattern with one that was predicted before the data was collected (Yin, 2018). In this case, there was a prediction of why African American males choose to teach, barriers they experience, and the roles they play from prior literature.

During the first-order coding process, codes from the interviews were broken down into the categories based on predictions related to the interview questions. For example, motivational factors for choosing education as a career path were determined prior to the interviews based on previously found research. Factors such as parental motivation, teacher inspiration, the need to mentor or change lives, and the lack of African American representation in the classroom were all predictions for why the participants would choose education. Once the interviews were complete, specific codes related to motivational factors emerged and were matched with previous patterns of 
motivational factors found in pre-established literature. This same process was carried throughout the interview questions with deductive pattern matching serving as the central means of analysis. Throughout the first-order coding process, the three central research questions were used as a guide to facilitate the coding process.

\section{Second-Order Coding}

Second-order coding methods are more advanced ways of reorganizing data coded throughout the first order and tend to focus on pattern codes, which are inferential and pull together material into smaller, more manageable units (Saldaña, 2016; Elliott, 2018). As the interview transcripts were analyzed for the second time, words that were spoken aloud were bolded, underlined, or italicized (Saldaña, 2016). In Vivo coding can provide a critical check on whether the researcher has ascertained what is significant to the participant and may help to condense meaning within the interview transcripts (Saldaña, 2016). By using terms and concepts that emerge from the participants themselves, researchers can capture meaning inherent in the experiences of the participants (Saldaña, 2016). In Vivo coding was used for this inductive data analysis because it prioritized the voices of African American male teachers (Saldaña, 2016). The CRT lens was particularly useful during second-order coding because it illuminated the stories of marginalization or alienation these men experienced during their journey to become teachers.

During the second-order coding process, the interview questions served as a guide once again. However, a deeper understanding of the concepts of racial microaggressions and the climate of the schools where these individuals worked was the primary focus of this inductive coding process. This process allowed the coded data to be analyzed more 
narrowly in attempts to address the three research questions of this study. For example, when motivations for teaching were coded, instances of racial microaggressions were analyzed and codes such as under-representation and lack of Black influences emerged as narrowed reasons for why these individuals chose education as a career path. The analysis for both the deductive, first-order coding and the inductive, second-order coding followed this same pattern of analysis with the interview questions and overall research questions serving as a guide to develop codes.

\section{Trustworthiness}

To ensure the credibility and trustworthiness of the interviews and the coding process, member checking was used to ensure that the data was strengthened because the researcher and participants in the study may have interpreted the data very differently (Korstjens \& Moser, 2018). By consulting with the participants themselves during the analysis process, "member checking" validated the findings, and the discussion provided an opportunity to articulate their internal thinking process as well as clarify any emerging ideas about the data (Saldaña, 2016). Transferability was ensured during this process by providing descriptions detailed enough so that the descriptions not only described the behavior and experiences of African American males but also the context in which they work (Korstjens \& Moser, 2018). These descriptions enabled the reader to assess whether the potential findings of this study were transferable to their context or setting (Korstjens \& Moser, 2018). Dependability, which is the stability of the findings over time and confirmability, the degree to which the findings of this study could be confirmed by other researchers, were strengthened by keeping an audit trail of the research process from the 
development of the research study until the reporting of the findings (Korstjens \& Moser, 2018).

Furthermore, after the initial first and second-order coding process was complete, a second researcher, trained in qualitative inquiry, read a minimum of $20 \%$ of the transcript pages. The secondary researcher was given the portion of interview transcripts, along with the coding sheet, and requested to complete the analysis. Next, a comparison of the coding of both sets of data was calculated to determine an inter-rater reliability score. A goal of greater than $80 \%$ was established to help ensure the reliability of the findings and a score of $92 \%$ was achieved during this process.

\section{Assumptions and Limitations}

Limitations emerged during the process of this research study. Fayette County Public Schools employs a limited number of African American teachers. According to the Kentucky Department of Education District Report Card (2018), in the 2016-2017 school year, 212 out of 2,834 teachers were African American (males and females combined). The anticipated sample size was small, no more than 20 due to the population of the group, and this too provided yet another limitation because of the number of available and willing participants. This limitation of participants is not unique only to Fayette County Public Schools, Kentucky, as is the case nationwide, because this school district is not an area where many African American teachers are employed. During the 2016-2017 school year, 1,482 out of 42,146 teachers statewide were identified as African Americans, males, and females combined (Kentucky School Report Card, 2018).

Other limitations related to case study methodology are the generalities of the findings and the issue that specific findings may not be able to be applied to all cases 
regarding the topic (Meyer, 2001). By selecting qualitative research, specifically case study research, limitations were accepted over which the researcher had no control, "Because qualitative research occurs in the natural setting and it is extremely difficult to replicate studies" (Wiersma, 2000, p. 211).

Because of the recent worldwide pandemic, limitations were placed upon the interview process. Interviews with the research participants took place via an online format (Zoom). Even though these online formats offer the capability of conducting interviews in a real-time and face-to-face environment, subtle nuances like body language, speech patterns, and reaction time were not as readily observable. Participants may also not have felt as comfortable seeing themselves in real-time video and so answers to questions may have been cut short to reduce the amount of time a person was on camera.

An additional assumption is that the interview participants would answer all of the questions honestly and factually (Meyer, 2001). There had to be a level of trust that the information provided was reliable enough to share in the study since the time taken to validate each response could be too cumbersome. One way to address this issue was by assuring the confidentiality and anonymity of the research participants in the study.

\section{Ethical Concerns}

It is important to consider the risks and benefits when conducting this type of research. Throughout the interview process, it was important to respect the privacy of the participants as the interviews were with specific and narrowed participants and so the risk of exposure for these participants was greater (Creswell \& Poth, 2018). Creswell and Poth (2018) suggest assigning pseudonyms, fictitious names, or developing composite 
profiles as a means to protect privacy when conducting interviews. For the purpose of this study, the participants were identified as Participants A through J.

This research study was conducted in a single school district with a limited number of African American male participants and so the risk of exposure for these individuals was high. The convention of confidentiality is a goal to protect research participants from any type of harm and exposure because the participants in this study may have feared retaliation or other negative consequences if their identities were exposed (Kaiser, 2009). I also participate in a Structured Ethical Reflection (SER) to guide the ethical decision-making process throughout the research (Stevens, BrydonMiller, \& Raider-Roth, 2016). The SER process allowed for the identification of core values and allowed me to examine how the specified principles such as courage, equality, leadership opportunity, respect, and social responsibility were embodied throughout the research (Stevens et al., 2016).

\section{Summary of Chapter III}

The purpose of this chapter was to detail the research methodologies that were used to address the research questions in this case study. A detailed discussion of the procedures, study participants, data collection process, and the data analysis process highlight the methodological process from start to finish. A formal discussion on the researcher, including assumptions, limitations, and ethical concerns related to this study were also included to illustrate the significance of this study, and serve as a reminder of their potential effects on the research process, as well as on participants and myself.

To conduct this research, the theoretical framework of CRT was used to develop theory and discussion on the motivational factors of African American males in choosing 
high school education as a profession. Barriers before and during their tenure as a teacher, the role of racism and microaggressions, and how these barriers affect classroom retention efforts were investigated through both deductive and inductive means. Throughout the first and second-order coding process, CRT and its tenets served as a guide, shedding light on race and racism within the educational setting, paying close attention to the marginalized voices of the study participants.

The data collected in Chapter III guided the reporting process that will take place in the next chapter. The goal of Chapter IV is to report the results of the study related to the interviews with the participants and to demonstrate that the methodology outlined in Chapter III was followed with fidelity. The upcoming chapter also serves as the foundation for recommendations and study implications that will be discussed in Chapter V. 


\section{CHAPTER IV}

\section{FINDINGS}

This chapter details the findings of the instrumental case study methodology conducted to answer the following research questions:

RQ1. Why are African American males pursuing a career in high school education?

RQ 2. What barriers do African American males face prior to and during their teaching careers?

RQ 3. How do the roles African American males are asked to fulfill contribute to their tenure as a teacher?

Chapter IV also examines the analysis approach of the interview transcripts to ensure consistency with case study methodology. Additionally, the demographics of the sample is detailed, using tables to complement the summary. Finally, the process used to analyze the transcripts from the 10 individual interviews identifies the two levels of analysis: (a) deductive coding using pattern matching techniques and (b) inductive coding using In Vivo techniques. Throughout the different levels of analysis, constant comparison was used to filter the data further, until specific themes began to emerge from the data. This chapter also includes findings from the interviews. Tables are used to present the various codes and emerging themes, as well as quotes from individual interviews that illustrate key themes that emerged. The following chapter is divided into three main sections that include: (1) Researcher Positionality (2) Data Collection and 
Analysis which incorporates the interviewee profiles and (3) Findings from a thematic analysis that corresponds to each of the overall three research questions by breaking them down into sub-sections related to first and second-order coding.

\section{Researcher Positionality}

Before analysis occurred, it was important for me to examine my own positionality as is related to the research topic and a Structured Ethical Reflection (SER) (Appendix D) was utilized as discussed in Chapter 3 to assess positionality. An examination of my racial and cultural heritage, as well as how my own background may influence the research process, took place during the data collection process (Milner, 2007). Examples of these self-reflective questions included: (1) asking myself about ways my racial and cultural backgrounds influenced how I experience the world, what I emphasized in my research, and how I evaluated and interpreted others and their experiences (2) asking myself, what do I believe about race and culture in society and education, and how do I attend to my convictions and beliefs about race and culture in my research (Milner, 2007). I reflected on my relationship with the participants in the

study as well, because it was important that I displayed empathy and possess an unbiased opinion related to the matter of African American males in teaching (Milner, 2007). I attempted to do this by sharing the entirety of facts discovered throughout the research process rather than opinions or judgments of the participants or the case itself (Milner, 2007).

Milner argues that after the interviews are complete, the researcher must engage in reflection and representation related to researcher positionality as it pertains to race and culture (2007). In relation to this topic, future researchers and I will need to engage in 
reflection with regard to what is occurring in the research community where race and culture are concerned (Milner, 2007). All researchers must understand and evaluate their own biases towards education, race, and culture to close and eventually eliminate the racial divide that separates so many individuals in the educational sector (Milner, 2007).

I had no direct relationship with any of the participants that would have caused a conflict of interest or insertion of bias into the research process. I attempted to form meaningful and trust filled bonds with the research participants so that the responses given during the interview process increased my knowledge of the roles and experiences of African American males in the high school setting. As a hiring administrator of a high school, it is important for me to find the information needed to help improve recruitment and retention efforts for my school and district as it pertains to African American males at the high school level.

By participating in a Structured Ethical Reflection (Appendix D), I was able to ensure credibility, transferability, dependability, and confirmability. The process also allowed me to identify core values in myself and how I would use those values throughout the research process. By continually reflecting upon my own core values, I was able to maintain focus on my research questions and my research participants so that I could better understand the lived experiences of African American male high school teachers in Fayette County Schools.

\section{Data Collection and Analysis Overview}

The data source for this research derived from semi-structured interviews with the 10 participants. After the interviews were complete, the next phase of data analysis consisted of transcribing and coding all of the interviews in order to begin determining 
emergent themes. First-order coding as described in Chapter III, used a deductive process to match previously determined a priori codes and match patterns based on prior literature research (Saldaña, 2016). Second-order coding used an inductive process of InVivo Coding to find themes that described instances of racism and microaggressions as described by the research participants (Saldaña, 2016). Further, to thoroughly capture this process, Microsoft Excel and NVIVO 12 were employed.

\section{Interviewee Profiles}

All 10 participants in this study were current high school teachers in Fayette County, Kentucky during the 2020-2021 school year. Twenty potential participants were contacted with 10 confirming participation. The breakdown of participants is included in Table 1 with their identifier, their race/ethnicity, gender, and their teaching content as defined as core (including Math, Science, English, or Social Studies) or other (elective content or special education). In order to protect the participant's anonymity, their years of teaching experience are separated into ranges of years from 1-10 years and 11-20 years.

Table 1. Demographics of Interview Participants

\begin{tabular}{lccccc}
\hline Teacher & $\begin{array}{c}\text { Referred to } \\
\text { as }\end{array}$ & Race/Ethnicity & Gender & $\begin{array}{c}\text { Teaching } \\
\text { Content }\end{array}$ & $\begin{array}{c}\text { Years of } \\
\text { Experience }\end{array}$ \\
\hline Teacher 1 & A & AA & M & Other & $1-10$ \\
\hline Teacher 2 & B & AA & M & Core & $1-10$ \\
\hline Teacher 3 & C & AA & M & Other & $11-20$ \\
\hline Teacher 4 & D & AA & M & Other & $1-10$ \\
\hline Teacher 5 & E & AA & M & Core & $1-10$ \\
\hline Teacher 6 & F & AA & M & Core & $1-10$ \\
\hline Teacher 7 & G & AA & M & Core & $11-20$ \\
\hline Teacher 8 & H & AA & M & Core & $1-10$ \\
\hline Teacher 9 & I & AA & M & Core & $11-20$ \\
\hline $\begin{array}{l}\text { Teacher } \\
10\end{array}$ & J & AA & M & Other & $1-10$ \\
\hline
\end{tabular}


Notes: AA = African American; M = Male; Core = Math, Science, English, Social Studies;

Other $=$ Electives/Special Education

\section{Findings from Thematic Analysis}

After the transcripts were coding using pattern matching (deductive) and In Vivo coding (inductive), themes related to each individual interview question were developed. Those themes were then analyzed even further to find emerging themes associated with racism and/or microaggressions. These emergent themes were then analyzed in relation to the overall three research questions for this study. The implications and conclusions for these three research questions will be reported later in Chapter V. The coding software NVIVO 12 was used to corroborate the information found within the initial coding phase using Microsoft Excel. After coding was complete, a word frequency analysis was run to ensure that there were no additional selective codes that needed to be explored. After a thorough analysis of the words, it was determined that there was not a need for further coding. The following table details the main codes and themes that emerged from the coding process as it relates to the three overall research questions. 
Table 2. Emergent Codes/Themes

\begin{tabular}{|c|c|c|c|}
\hline Research Question & First-Order Codes & Second-Order Codes & Themes \\
\hline $\begin{array}{l}\text { RQ1: Why are African } \\
\text { American males } \\
\text { pursuing a career in } \\
\text { high school education? }\end{array}$ & $\begin{array}{c}\text { Family/Teacher } \\
\text { Inspired; } \\
\text { Coaching opportunity; } \\
\text { To be a role model; } \\
\text { To pay it forward } \\
\end{array}$ & $\begin{array}{l}\text { Wanting teachers who } \\
\text { looked like them; } \\
\text { Break the cycle of } \\
\text { negativity }\end{array}$ & $\begin{array}{l}\text { Altruistic response to } \\
\text { lack of representation }\end{array}$ \\
\hline $\begin{array}{l}\text { RQ2: What barriers do } \\
\text { African American males } \\
\text { face prior to and during } \\
\text { their teaching careers? }\end{array}$ & $\begin{array}{l}\text { Prior to teaching: } \\
\text { Time management; } \\
\text { Academic barriers; } \\
\text { Neighborhood } \\
\text { Pressures; } \\
\text { During teaching: } \\
\text { Teacher autonomy; } \\
\text { Teacher tenure; } \\
\text { Lack of Admin Support } \\
\text { Constant Changes }\end{array}$ & $\begin{array}{c}\text { Prior to teaching: } \\
\text { Spokesperson for the } \\
\text { race; } \\
\text { Being a minority in the } \\
\text { school; } \\
\text { Name calling; } \\
\text { Isolation } \\
\text { Racial Stereotypes; } \\
\text { During teaching: } \\
\text { Lack of equity } \\
\text { Silence } \\
\text { Isolation } \\
\text { Microaggressions }\end{array}$ & $\begin{array}{c}\text { School and } \\
\text { Neighborhood } \\
\text { Pressures; } \\
\text { Awareness of Minority } \\
\text { Status; } \\
\text { Isolation }\end{array}$ \\
\hline $\begin{array}{l}\text { RQ3: How do the roles } \\
\text { African American males } \\
\text { are asked to fulfill } \\
\text { contribute to their } \\
\text { tenure as a teacher? }\end{array}$ & $\begin{array}{c}\text { Coaching } \\
\text { Mentor } \\
\text { Club Sponsor } \\
\text { Student advocate } \\
\text { Academic content lead }\end{array}$ & $\begin{array}{l}\text { Discipline lead; } \\
\text { Teacher for grade } \\
\text { recovery class; } \\
\text { To fill a needed gap; } \\
\text { Black role model; } \\
\text { Stereotypes }\end{array}$ & $\begin{array}{c}\text { Traditional teacher roles } \\
\text { focused towards } \\
\text { minority students; } \\
\text { Typecast Minority } \\
\text { Roles }\end{array}$ \\
\hline
\end{tabular}

\section{Motivational Factor Themes}

As the participants recounted their motivations for choosing education as a career, the main theme of altruism seemed to be the overarching commonality amongst the 10 participants. The participants felt the need to give back to their community as well as their race. The theme of altruism can be attributed to the codes that were revealed during the coding process. These codes are used in the following sections to validate the theme of altruism. Quotations from each coding process will also be highlighted to demonstrate the participant's desire for altruism.

First-Order Codes. During the first-order coding cycle, many of the motivational factors found in previous literature emerged as familiar reasons as to why an individual would choose education as a career. The first order codes that surfaced included 
family/teacher inspiration, coaching opportunities, to be a role model, and to pay it forward. For the research participants, their motivations to become a teacher were overwhelmingly family and teacher inspired, with six of the 10 participants listing a family member or past teacher as the reason they chose education as a career path. Three of the participant's parents were already in education and so it was a familiar career choice for these individuals. Because of the family and teacher call to altruism in a previous generation, these participants chose to go into education. There was this sense of paying it forward to a new generation, and Participant G spoke of these altruistic family and teacher motivators by remembering a teacher who inspired him. "So there was this teacher who pulled me aside and basically convinced me to become a teacher and I will never forget her."

The remaining four participants cited the need to be a role model, feeling as though it was a natural fit for them because of their familiarity with the career, wanting to pay it forward, and seeking an opportunity to be a coach as their motivation. All 10 participants described the need to impart knowledge and educate others as determining factors in their desire to become an educator, which substantiates the theme of altruism.

Second-Ordering Codes. After further examination of the transcripts, second-order coding was employed using In Vivo coding. Using the lens of CRT, the motivational factors influencing these participants were examined to expose any instances of race or racism that may have influenced their career choice. Of the 10 participants, five cited factors related to race and those factors were coded as the desire to see teachers who looked like them and breaking the cycle of negativity. Participant B and $\mathrm{H}$ both made comments about lack of representation from African American male teachers while they 
were growing up. Other participants discussed how it was extremely important for them to be the representation that they did not have growing up, especially for their students of color.

Participant I was inspired to go into teaching after reading an article in a paper citing a need for black teachers in the classroom. He spoke of the times when he was in school that he wished he had seen more individuals who looked like him. When he read this article in the paper, he felt that call to altruism to be the representation that was needed. This lack of representation in school was considered to be a negative experience for these participants and so in order to stop the cycle of negativity that many underrepresented students face, teaching became the solution. Just one of the examples of negativity experienced by students of color was when Participant F discussed his time working as a counselor at an alternative school setting. He mentioned seeing the same types of students repeatedly. The students with the same issues, the same behaviors, and often students of color were being sent to this facility and Participant F wanted to know what the common denominator was. He also started to examine the types of teachers being sent to this facility. He observed that the teachers being sent to this facility to work with the most difficult students were the ones who had difficulties in their previous districts or were near retirement. These students already had a very negative perception of education and to be taught by teachers who were not invested in them really bothered Participant F. Therefore, he decided to go back to school and get a teaching degree because it was a role he was already fulfilling for the kids in this facility. He wanted to stop the cycle of negativity for these students and so he felt it was his altruistic calling to, "Get on the inside of this problem and start to learn a little bit more." Table 3 lists some 
sample quotations that speaks to the themes of altruism and lack of representation uncovered during the first and second order-coding phase.

Table 3. Motivational Factor Theme Sample Quotes

\begin{tabular}{|c|c|c|c|}
\hline Research Question & Theme & Participant & Sample Quote \\
\hline \multirow[b]{3}{*}{$\begin{array}{l}\text { RQ1: Why are African } \\
\text { American males } \\
\text { pursuing a career in } \\
\text { high school } \\
\text { education? }\end{array}$} & $\begin{array}{l}\text { Altruistic response to } \\
\text { lack of representation }\end{array}$ & $\mathrm{H}$ & $\begin{array}{c}\text { I had a whole bunch of } \\
\text { quality teachers and I } \\
\text { wanted to be that for } \\
\text { my students. }\end{array}$ \\
\hline & & $\mathrm{E}$ & $\begin{array}{l}\text { Just knowing that I } \\
\text { had that experience, } \\
\text { you know, I wanted to } \\
\text { be able to offer that } \\
\text { experience to future } \\
\text { generations. }\end{array}$ \\
\hline & & B & $\begin{array}{l}\text { The biggest reason I } \\
\text { went into teaching was } \\
\text { I didn't have an } \\
\text { African American } \\
\text { male teacher until I } \\
\text { was a sophomore in } \\
\text { college and so that } \\
\text { experience caused me } \\
\text { to reflect and think } \\
\text { back and say, okay, } \\
\text { why is that? What } \\
\text { happened along the } \\
\text { way that I missed out } \\
\text { on having that voice, } \\
\text { having that person } \\
\text { who inspired me? }\end{array}$ \\
\hline
\end{tabular}

\section{Why High School Teaching?}

When asked about the motivation to teach high school aged students instead of

other grade levels, all 10 participants cited relatability as the primary reason for choosing high school education. Many of the participants discussed the ease of speaking with students this age and the need to mentor and inspire them. Participant A wanted to inspire students and help them to see, "That your life is so much more than where you are at this moment." There was an evident need to share the gift of opportunity with students at the high school level so that they could see beyond their friends, neighborhood, and 
circumstances in order to go on and do greater things after high school. "Greatest impact" was a phrase often used by the participants, and as Participant A commented, this age group, "Was one of the last opportunities to really impact a student before they embark on the journey of life as it were. Participant B also shared that, "I felt like I could have a little bit more of an impact at that level." This rationale provided for the choice of grades helped to reinforce the altruistic theme of why they chose to teach. There was no discussion with regard to race in why these participants chose high school education over other levels. Their choice of high school education relied more heavily on the aspect of altruism as they sought to create opportunity and change for their students before embarking out into the real word.

\section{Barrier Themes}

After the participants shared their motivations for teaching, the next set of interview questions transitioned to their own experiences in school during their K-12 education, university education, as well as in their current job setting. Many of their experiences, not all negative in nature, shaped who they were as men and as future educators. These experiences were coded first as predictive barriers they may have faced prior to and during their teaching career. Second order coding, looking through the lens of CRT, revealed experiences specifically related to the participants as African American boys and men during their schooling and within their current roles as educators, especially when instances of racism and race were involved. The three emerging themes that were uncovered during the coding phase of this research were school and neighborhood pressures, an acute awareness of their minority status, and isolation. The first theme that was uncovered is a theme that is not uncommon to students in general. 
The two themes uncovered during second order coding (minority status and isolation) were two central barriers the participants experienced prior to becoming a teacher as well as after starting their career. The next sections will detail their experiences and discuss the codes that support the themes as it relates to research question two.

\section{Barriers Prior to Teaching}

First-Order Codes. First-order coding uncovered barriers such as time management, academic barriers, and neighborhood pressures as reasons these individuals may have struggled in school. Although two of the participants mentioned lack of general academic skills, none of the participants expressed any severe deficiencies in their academic skills during their time in K-12 and only one participant mentioned academic struggles that occurred while in college. Although these codes were mentioned, they were not uncommon barriers for all students in school.

Neighborhood pressures became a barrier for Participant $G$ who said he grew up in a rougher part of town and often had pressures from the neighborhood that would distract him from his academic goals. Two other participants talked about the pressures of the neighborhood and the need to fit into an academic society as well as the neighborhood society. These dual roles often left the participants with a sense of obligation to both entities and according to them, added unnecessary stress to their lives.

Many of the same first-order code barriers were common among the participants in both K-12 schooling and their university careers. Three of the participants cited lack of time management skills as an obstacle they had to overcome during their time as university students. Participant B described how his biggest struggle early on was how to manage time without having his parents in the background telling him to do his work, his 
chores, and all those other things that come with being an adult. All these codes were grouped together under the theme of school pressures.

Second-Order Codes. Upon further investigation of the interview transcripts, second-order coding employed inductive coding to discover themes related to race and racism. All 10 participants, without prompting, discussed some aspect of race that was meaningful enough for them to recount that occurred during their K-12 and collegiate experiences. Nine out of the 10 participants recounted what they deemed as negative experiences during their schooling, with only one participant (Participant D) not citing race as a barrier growing up. All other nine participants in this study described several instances of racism and microaggressions during their years of K-12 and collegiate education. The participants spoke of how they were the minority in their schools and how they were able to recognize this early on based on the conversations happening around them as well as an acute awareness of their skin color versus the majority of their peers. Most were called names from both White and Black peers. White students would call them racial slurs like nigger, while other Black students would call them terms like "white" or "inside-out Oreo" because they felt as though the participants were trying to assimilate into the White culture because they demonstrated an affinity for academics.

Two of the participants discussed the racial stereotypes of African Americans as minorities in history as a barrier they faced during their K-12 school years. Participant I remembered being shown pictures of Black people being happy in the tobacco fields, just smiling and waving. He recalls that he did not realize until later that no slave would have been that happy to be out in the fields all day working. He realized that his true ancestral history was being covered up and it made him acutely aware of his status as a minority in 
his school and the stereotypes that many minorities fall into. Participant B was asked to play the role of spokesperson for the African American population by his teachers when he was in school. He remembered a great sense of isolation when his class was reading To Kill a Mockingbird. "I was the only student that was allowed to read the passages with the N-word in it, and it sort of made me feel isolated."

Participant A also felt this sense of isolation and stereotyping when he described being identified based on his race. He would be pulled out of class to meet with a person and would be asked to sit in a circle and talk about being Black, how Black leaders should act, and how they should do things for their community. He realized that this was a program that appeared to be geared towards at-risk Black youth. He also remembers being asked into the counselor's office with what seemed to be at-risk Black males. $\mathrm{He}$ would be asked how he was doing in school and what his grades were like. Many of those students would talk about their low grades in class while he would have A's in all of his classes. He was continually pulled out of class until his parents intervened and told school administration that they were hindering his education by pulling him out of class for no reason. I then asked Participant A a clarifying question by asking him if there was ever a real purpose explained to him as to why he was being pulled out of class. His response was,

"No. If anything, it made me feel as though I was a statistic. I mean, it made me think like, do you guys think that just because I'm a Black male, I'm gonna screw up in school and go to jail. It just kind of exacerbated any stereotype of the Black male in my opinion. I mean, here I am in the top quarter of my class, I come from 
suburbia, and both of my parents have advanced degrees. Why am I here? It was never explained to me and that made me feel as though, like am I at risk?"

Once the participants entered college, most discussed the variety of opportunities that were afforded to them once they were in that environment. For most, college was a welcome environment, likely this is attributed to eight out of the 10 participants attending colleges or universities that were more diverse than their K-12 environments. The two outliers, (Participant A and Participant F) had different experiences while in college. Participant A went to a college that was more diverse than his K-12 experience, but there was still this great segregation occurring among the Black and White students. Participant A considered himself, "ethnically ambiguous"; so many people did not know how to really place him. As a result, he did not seem to fit in with any crowd. When he did associate with White students, he would often hear them ask why the Black students segregated themselves. According to him, this same question was never asked of the White students.

Participant F's university experience found him in a small rural town of Kentucky at a predominately-White university. He was there to play sports and experienced what he described as "culture shock" due to the lack of minority representation on the campus. $\mathrm{He}$ recalled maybe eight Black people on the campus, four or five of those being on his team. What he found most interesting was that race was not the primary factor in the divide among the campus, although he was very much aware of his minority status. $\mathrm{He}$ discovered this after his first year when a group of White athletes from a different state transferred to the university and they were not well received by the local students. $\mathrm{He}$ uncovered that not being from that town caused a cultural divide for any student, no 
matter their race. As an athlete, he also had to deal with the stereotype that he was not smart and was only there for sports. Many of his professors tended to treat him differently as an athlete, but he reported that navigating these isolating barriers in college helped him to grow as a person.

\section{Summary of Barriers Prior to Teaching}

During first-order coding many of the barriers, many of the participant experiences were not uncommon with barriers other students must endure during their time in K-12 and college. Many of them experienced lack of motivation, time management issues, neighborhood pressures, and academic barriers. These codes were grouped together under the theme of academic and neighborhood pressures. Upon further investigation of the interview transcripts, second-order coding, looking through the lens of CRT, revealed nine of the participants experienced name-calling, barriers associated with race, stereotyping, and feelings of isolation. These codes manifested themselves into the themes of awareness of minority status and isolation. Sample quotations demonstrating these themes are listed in Table 4 below. Once these barriers were traversed, the participants journeyed into the career of education at different junctures in their lives. Once employed, many have found successes as a classroom teacher but there still seems to be lingering issues related to their roles as African American male high school teachers. 


\section{Table 4. Barriers before Teaching Theme Sample Quotes}

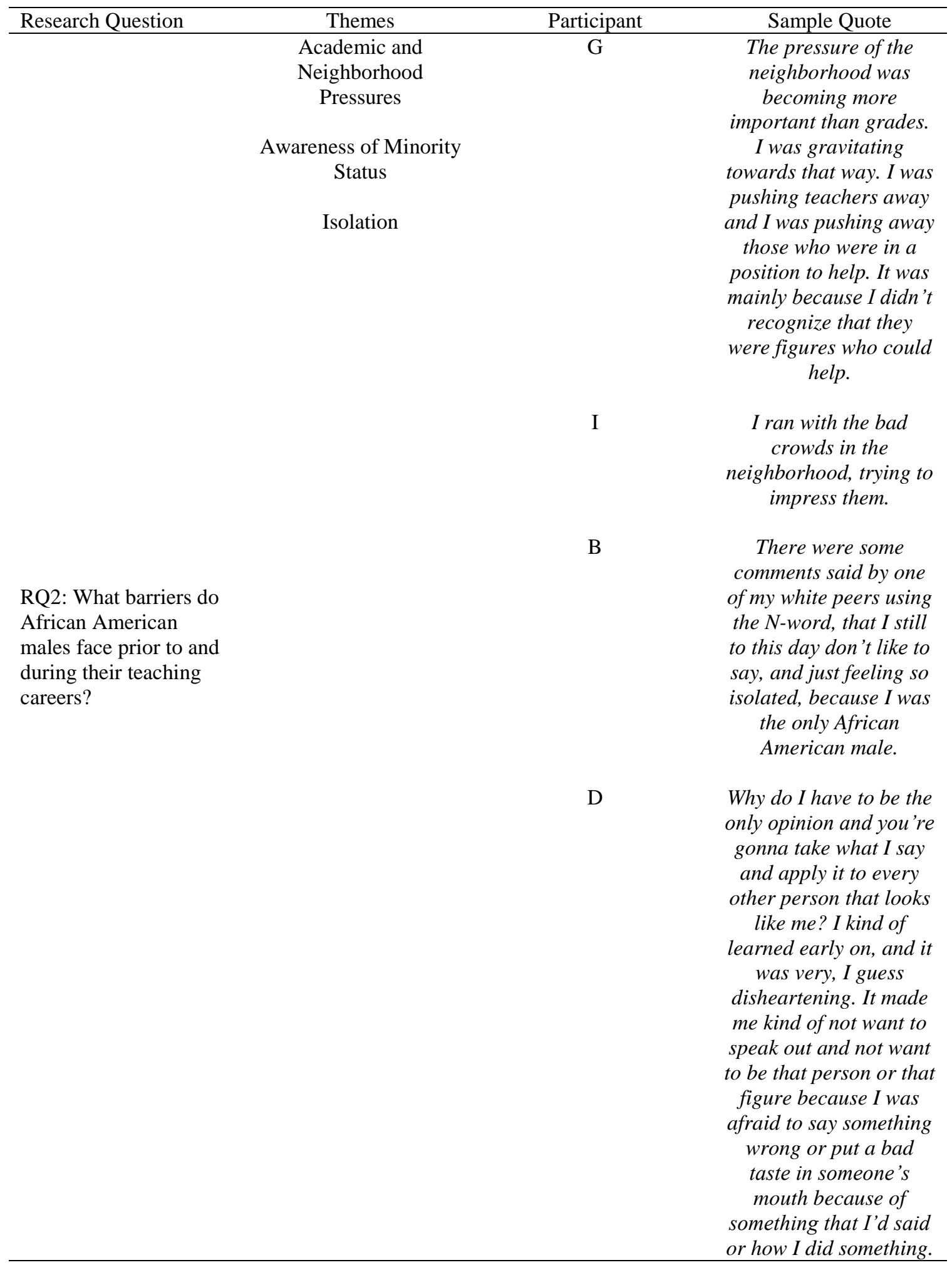




\section{Barriers during Teaching}

First-Order Codes. As the participants completed their formal educations and began to pursue teaching as a career choice, I wanted to explore what barriers they were experiencing in their current job setting that could later be discussed in Chapter $\mathrm{V}$ as recommendations for solutions. When asked how the participants obtained their first jobs in Fayette County, none of the participants recorded that they were actively recruited for the positions. Four out of the 10 participants said that they were recruited to coach a sport in the school they are in now and teaching was a secondary position that came about because of the coaching position. Four other participants knew someone who was already employed in the building or within the district and so they had insider's information as to the open position and all felt as though being known by someone helped get them the job. The other two participants were not coaches or did not know someone already in the building and so they had found the job on their own and applied for the position.

When asking specifically about their first year of teaching, I wanted to determine what types of support they were given that might have made that first year easier. All 10 of the participants discussed some basic support systems that first year of their careers in Fayette County, whether it was KTIP (Kentucky Teacher Internship Program) or Fayette County's NTI Program (New Teacher Induction). The issue that was exposed was that although there were systems in place, those systems did little to nothing to offer support in their first year of teaching. In particular, none of the support systems were targeted towards minority educators. All 10 participants also mentioned some informal support given to them by their departments or an assigned mentor teacher within the building. 
When the participants were asked specifically what barriers or struggles they currently deal with in their current placement, there was a range of answers including teacher autonomy, lack of administrative support, fear of not receiving tenure, and constant changes. These codes all fell into the overall theme of school pressures that was also discussed as barriers before teaching. These barriers were predicted and confirmed during the interview and coding process as barriers that are not uncommon for teachers in general. School pressures as a theme encompasses many of the codes listed above as reasons teachers may find difficulties performing their everyday tasks as teachers.

Seven of the 10 participants were within their first to tenth year in education and youth was discussed as a barrier as it pertained to teacher tenure. Some of the participants believed that their youth was a barrier because they were not as experienced as some of the other teachers in their department or their building and so they were not as confident in speaking out about issues in which they felt passionate. Participant B spoke of his youth and said that he had found that the more tenured and experienced teachers felt like they had it all figured out. As he was earlier in his career, he felt as though he could not speak up or, “I couldn't have too loud of an opinion because those older, more experienced voices kind of outweighed what I thought." Participant A and Participant I both echoed these same sentiments about teaching and lack of autonomy when discussing barriers.

Three of the participants $(\mathrm{C}, \mathrm{D}$, and $\mathrm{G})$ cited constant change as a yearly barrier they must endure in their current job setting. Whether the changes were from inside the building, the district, or the state level, there was a sense of frustration-based answers given by these participants. Although these participants recognized the need for changes, 
the constant uncertainty and lack of clarity surrounding those changes created barriers that these participants felt were unnecessary.

Lack of administrative support was a barrier mentioned by two of the participants. Participant $\mathbf{J}$ cited a genuine lack of support for his program and said there was a difference between acknowledgement and support. "It's one thing to say, yes, I see you, but it is another thing entirely to say, how can I help you and how can I help your program or bring attention to this." Participant $\mathrm{H}$ also spoke of a lack of administrative support as it pertained to difficult parents. In general, he said he was supported by his administration but when parents complained, their complaints were listened to and teachers were not often supported.

Second-Order Codes. As I explored these barriers even further during secondorder, inductive coding, more barriers were revealed that focused on the tenets of CRT. Lack of equity, racial stereotypes, silence, awareness of minority status, spokesperson for the race, and isolation were concerns that were expressed by some of the participants during second-order coding. As it relates back to the hiring practices discussed previously in the first-order coding of this section, only one of the participants revealed any themes of race related to their hiring. Participant $G$ recalls being interviewed by the principal of the school who he remembers was a Black woman. During the interview, he said it appeared as if the principal was not paying attention to anything he said but after the interview pulled him aside and said, "We have some other candidates still to interview, but I have my mind set on you because we need an African American here in this role." The role he was interviewing for was the In-School Detention/Suspension teacher, which dealt with many of the behavior problems in the school. Initially, Participant G was 
excited by the comment and then pondered on what she really meant by her statement. He was hired for the job and said the job ended up turning out the way he thought it would after she had made that comment. For him the experience was very negative, and he no longer works at that location and is no longer an In-School Detention/Suspension Teacher.

Participant G's lack of administrative support revealed instances of racial barriers and lack of equity that were exposed during second-order coding. Many of his parent complaints arose out of the way he taught the content and tried to shed light on the plight of African American people. He felt as though it was his duty to expose all students to the realities of the world and because he had experienced his, "Fair share of racism", he wanted to be sure to include that in his teaching pedagogy.

'I'm trying to save my life, I'm trying to save my daughter's life, and I'm trying to save my brother's life. It is important that the White student sitting in my classroom is exposed to the experiences of the Black student that is sitting next to them has lived through. Because when I tell my own story to my Black students, I have never heard them say, I don't know what you are talking about." Participant $\mathrm{F}$ felt a lack of equity concerning how his administration handled discipline issues with teachers in his building. He felt as though because he was an African American male it was assumed that he would garner more respect in his classroom and have fewer management issues. He observed many of his colleagues having classroom management issues and would witness the associate principals responding to their needs very quickly. When he had issues, Participant F was confronted with a lack of support and the response would be, "Oh, you can handle it and we want 
you to work it out." Participant F wished he had more support in that area and as a follow up, I asked if the classrooms that were given more support by administration were of teachers who were non-minority and he said yes, the teachers who were given the most support in classroom management were the White teachers. Participant F assumed this occurred because there was this belief that minority teachers were better versed in classroom management techniques and he wished that those racial stereotypes did not exist within the confines of the educational system.

The lack of equity was seen in the makeup of the classrooms and schools the participants worked in as well. Participant I spoke of the lack of equity concerning the types of students he sees in his school and classroom. The barrier that he witnesses in his daily job are the amount of minority students (Black and Hispanic) that are in trouble in his school and who are often sent to the district's alternative school. "Where do the White kids who are bad and who are in trouble go? They don't show up at the alternative schools like the other kids, so where are they going?"

One of the most prevalent barriers facing these individuals is the extreme isolation they feel because of being one of only a few, if not the only minority in their school. Participant $\mathbf{J}$ spoke most about the phenomena of isolation, as he is currently one of the only African American male teachers in his building. He recounted the lack of cultural connection he often feels with his colleagues and felt like he should not be in a situation where he is one of the only people in his school who looks like him. He said it would be nice to have other people who understood the same things as him, who understood the language, and the vernacular of the cultural traditions. A strong desire for a community of like-minded men who support one another was communicated, but there was also a 
recognition of the stigma surrounding Black men in general that often made this type of community building difficult. Participant $\mathrm{G}$ even described himself as a, "Pink unicorn with stripes who breathes fire"; because he knows that being a Black male in education is a rarity.

In total, four participants $(\mathrm{A}, \mathrm{G}, \mathrm{H}$, and $\mathrm{J})$ expressed aspects of isolation as a barrier to their current teaching role. Participant A spoke about how it was hard for men like him not to acknowledge that they are Black men. Because of other individual's lack of knowledge and their own isolation from Black people, many of the ideas that others express come across as prejudice or misinformed. Participant $\mathrm{H}$ discussed many of these same sentiments when he spoke of trying to expose his students to ideas and ways of thinking that are going to make them better human beings, more compassionate, and more empathetic.

Participant $\mathrm{H}$ championed the individuals he is able to call on for help as, "allies". These allies help fight that isolation and for him, it is comforting knowing that there are other people who don't look like him who are also fighting for him to be safe because, "It is exhausting to always feel like you're the only one." Because of this isolation, at times, microaggressions can result from colleagues. For Participant $\mathrm{H}$, it became very isolating for him when he felt as though his colleagues were not paying attention to the world around them. He said their actions do not make him feel as though they care, and for him, it was important that educators make other educators feel comfortable, safe, and valued. "The most painful things that have happened to me in my years of teaching have been the comments that co-workers have made that they don't even realize they have made." He 
said he has also had colleagues tell him in passing that he talks about race too much in his classroom. For Participant $\mathrm{H}$ this is very difficult to hear because,

“On multiple occasions I have had scary run-ins with police officers. It's difficult to not talk about race as a Black man in America when you were a child, a woman said she wanted to drag you by a noose. So to feel comfortable enough to say to a colleague that you talk about race too much can make someone want to leave the profession because we're supposed to be allies in this."

Participant J commented that for black men, “There's a lot of silence that African Americans sort of have to carry with them into the workplace, because a response in any way just potentially yields more than it's worth." Because of this isolation and acute awareness of their minority status, these individuals often experience a lack of autonomy and decision-making power that makes it difficult for them to feel as though they are part of a team. Participant $\mathbf{J}$ also discussed the importance of different perspectives but dealing with stereotypes, cultural appropriation, and explaining to students why those things are not good is, "A lot of responsibility for two or three people in the school." Table 5 below reveals the voices of these individuals as it relates to the themes found within the barriers faced during their teaching experiences.

Table 5. Barriers during Teaching Theme Sample Quotes

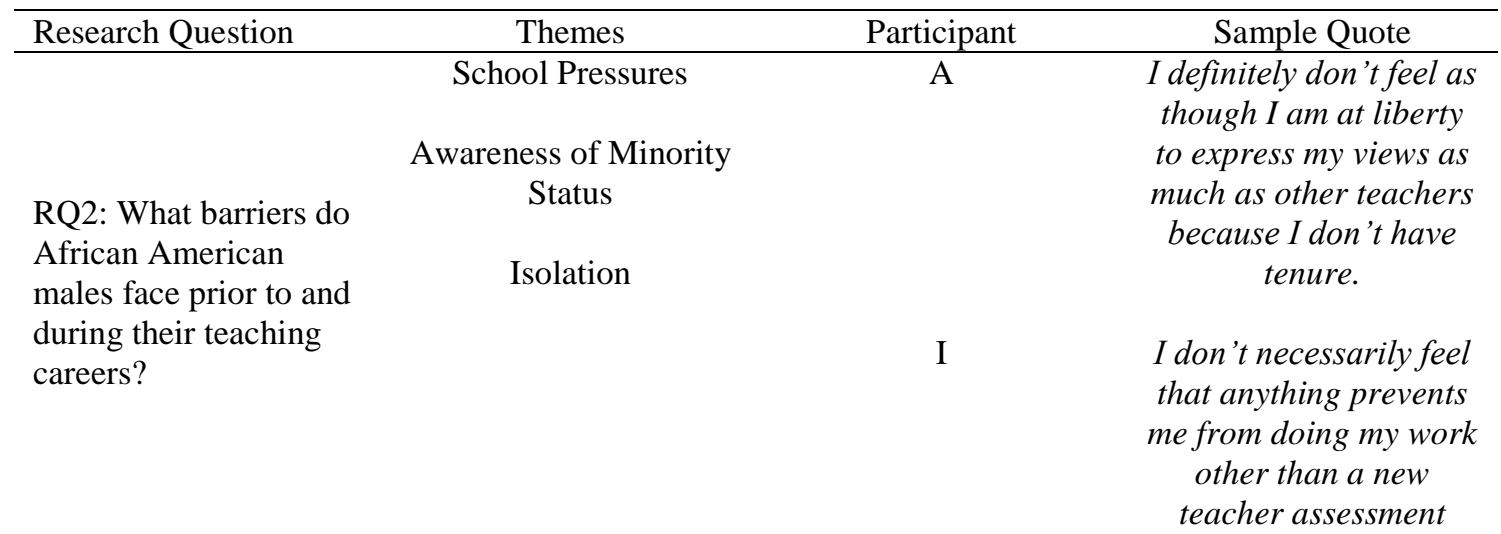




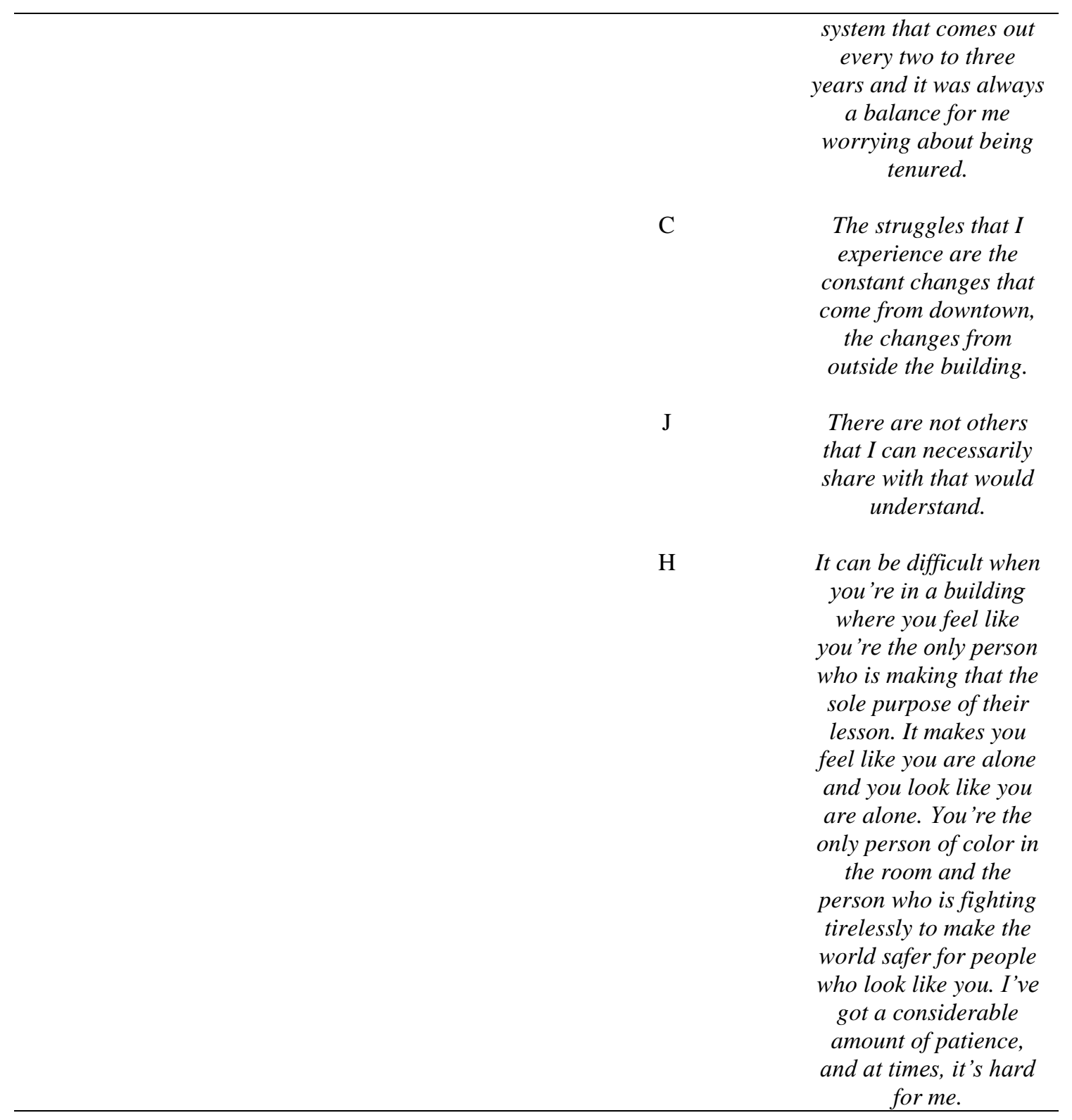

\section{Summary of Barriers}

The interviews for this study revealed barriers in teaching that were not uncommon to African American male teachers across the country, as evidenced by previous literature exploration. Both first and second order coding techniques exposed barriers that these individuals feel hinder their ability to do their jobs to the fullest, thus adding undo stress to a profession that can itself be stressful. Within Fayette County, it 
was possible that these individuals experienced barriers related to their race that many might not have been aware of prior to this research. These barriers exposed themselves as themes of minority status and isolation. The silence that many of them carry daily as a minority male educator can be exhausting as personally described by one participant. The implications and recommendations to these barriers is discussed in detail in Chapter V.

\section{The Roles of an African American Male Teacher}

As teachers work to shape the minds of their students, imparting knowledge in Science, Mathematics, English, and other contents is just the tipping point of the responsibilities a teacher takes on during their career. The roles and responsibilities can be multifaceted, and at times, prove to be overwhelming to educators, in particular African American educators. Although some roles are sought after, other roles are thrust upon them because of their race and gender. The participants in this study were questioned about the roles they fulfill outside of a classroom teacher and if these roles were sought or placed upon them.

First-order coding revealed roles that were not uncommon to teachers including athletic coaching, mentoring, club sponsor, content lead, and student advocate. Secondorder coding revealed roles and responsibilities that were not predicted but coincided with the tenets of CRT. All 10 participants reveled roles that that they sought out or were placed upon them because of their race and gender. Specific instances of racism and microaggressions were more prevalent in some of the participant's experiences than others. Second-order, inductive coding revealed codes such as disciplinarian, teacher for recovery classes, Black role model, stereotypes, and the need to fill a gap. The overall 
themes that emerged from the coding process were traditional teacher roles and typecast minority roles.

First-Order Codes. Athletic coaching roles were very prevalent among the participants. Six of the 10 participants held some type of athletic coaching role and those roles were pursued at their individual schools. For three of those participants, coaching was their primary role at their school and then they were later hired as a full-time teacher. None of the participants who held coaching roles expressed any instances of racism or microaggressions that had taken place within their coaching realm.

All of the participants who served as coaches found that their role made it easier to connect with students. By connecting with students, they took on a mentoring and advocate role that they found as a welcomed role outside of the classroom. All 10 participants, even those who did not have a coaching role, discussed this mentoring role. As an educator, the participants felt like mentoring and advocating for students was a natural progression in their role as a teacher. Many of the participants expressed concerns that if they did not serve as a mentor or student advocate, then many of their students would not have anyone to fulfill that role.

Four of the 10 participants served as club sponsors and content leaders outside of their roles as a teacher. Some of these roles were wanted and some of them were asked to serve in these roles. The issue of teacher tenure was again brought up during this discussion of roles. Three of the participants had this impression that if they did not take on additional roles that they may not be seen as a team player and they would be asked to not return to their teaching roles. One participant was told by a fellow colleague that he was to do as much as he could in the first few years until he was tenured because then it 
would be harder to get rid of him. According to Participant B, by taking on more responsibilities it became easier to decide between the person who held a lot of responsibilities as opposed to someone who just taught when it came down to filling one remaining teaching position. There appeared to be this underlying fear of losing their job if the participants were not willing to take on more duties outside of the classroom.

The apriori codes that were predicated prior to coding were confirmed once the coding process was complete. All of the codes that surfaced fell under the theme of traditional teacher roles that any educator would fulfill regardless of their race or gender.

Second-Order Codes. Although mentoring and advocating for students is seen as a traditional teacher role, the students who these participants were asked to mentor or advocate for were most often the minority students. Participant E believed that his role as a role model and mentor helped because, "I know some of them just need that extra voice of actual support that they might not get from home or from anywhere else in the community." Participant J echoed these same sentiments, as he wanted, "To help his minority students find a sense of identity and a safe space.” Even those who did not actively seek out this role were put into the position because their students of color would seek them out. He did express his reluctance to sometimes accept this role because he does not feel qualified and he is not a trained counselor. "But then I think, if you are coming to me to have this conversation, there's no telling who else you're going to have this conversation with, and I know I'm going to give you better advice then they will."

As the participants discussed their roles within the school, roles that stood out that had obvious correlations with CRT occurred when the participants were asked to serve as stereotypical defacto disciplinarians or credit recovery teachers for predominately low 
performing minority students. Five of the 10 participants discussed instances of these typecast roles occurring in their schools and each of them expressed a level of frustration at having to play these roles because they were African American men. Participant E expressed frustration that it was assumed because he was Black that he would have a better handle on classroom management techniques. "It is assumed that I'll be able to snap my finger and everything will work out. That's not always the case." When he sees his White colleagues having classroom management issues, the principals in the school go right into their classrooms while he struggles to get support for the issues he has.

Participant $\mathrm{F}$ discussed his unofficial role as the teacher who gets to deal with certain types of situations and students. If something is getting ready to happen in his building that may disrupt the students or the building, many of the teachers will go to him to handle the situation before it escalates. Although he recognized his strength as being an individual who can deal with these types of situations, he also recognized the issue of other teachers giving up their own power and authority when they ask him to deal with these situations. I asked Participant $\mathrm{F}$ a clarifying question by asking him if he thought the other teachers would approach him in the same manner and ask him for his help if he were a White male teacher. His assumption was no, and he said he has wondered why this stereotype has existed for years.

Microaggressions and typecasting were also seen in the school master-scheduling process when these teachers were asked to teach certain populations of students. Participant B discussed being intentionally given some of the worst students in the building. He was given more of the behavior issues, academically challenging students, and was asked to teach a repeat freshman credit recovery course that consisted mainly of 
African American males. His counselor told him that he was given that cohort of students because he was able to relate to them better. A follow-up question was asked to determine the race of the counselor. The counselor was identified as a minority. Participant B recounted that it was very evident from the beginning that he was given these students for a purpose. "That purpose was because I look like them." He said the counselor tried to pitch it as he had most of those students in the previous year, so they knew him. The counselor said,

"So you have already had them last year and you already have a relationship with them and they look up to you. I see them in the hallways dapping you up and they talk to you on their way to class and they come and seek you out."

Participant B said stuff like that has really worn on him because it was evident he was given those students for a specific reason. He understood and accepted his role in those student's lives because he grew up in the same neighborhoods as them and came from a single mother household like them. One of the reasons he pursued a career in education was to be an advocate and role model for those students. He did acknowledge that these situations are a bit off-putting. As a follow up to that response, he was asked his opinion on how he is seen more often, as a teacher or an African American male. His response was, "I think by the students I'm seen more as the advanced (content) teacher, AP (content) teacher, but by the administrators, the other teachers, especially the counselors, I'm seen as the Black male teacher."

Overwhelmingly, the codes that were revealed during this analysis phase promoted the theme of typecast minority roles. These typecast minority roles were not placed on teachers who were White and thus, added additional responsibilities that the 
participants vocally expressed frustration with. Table 6 below reveals some of the quotes associated with the overall roles many of these individuals were asked to fulfill.

Table 6. Roles of the Teacher Theme Sample Quotes

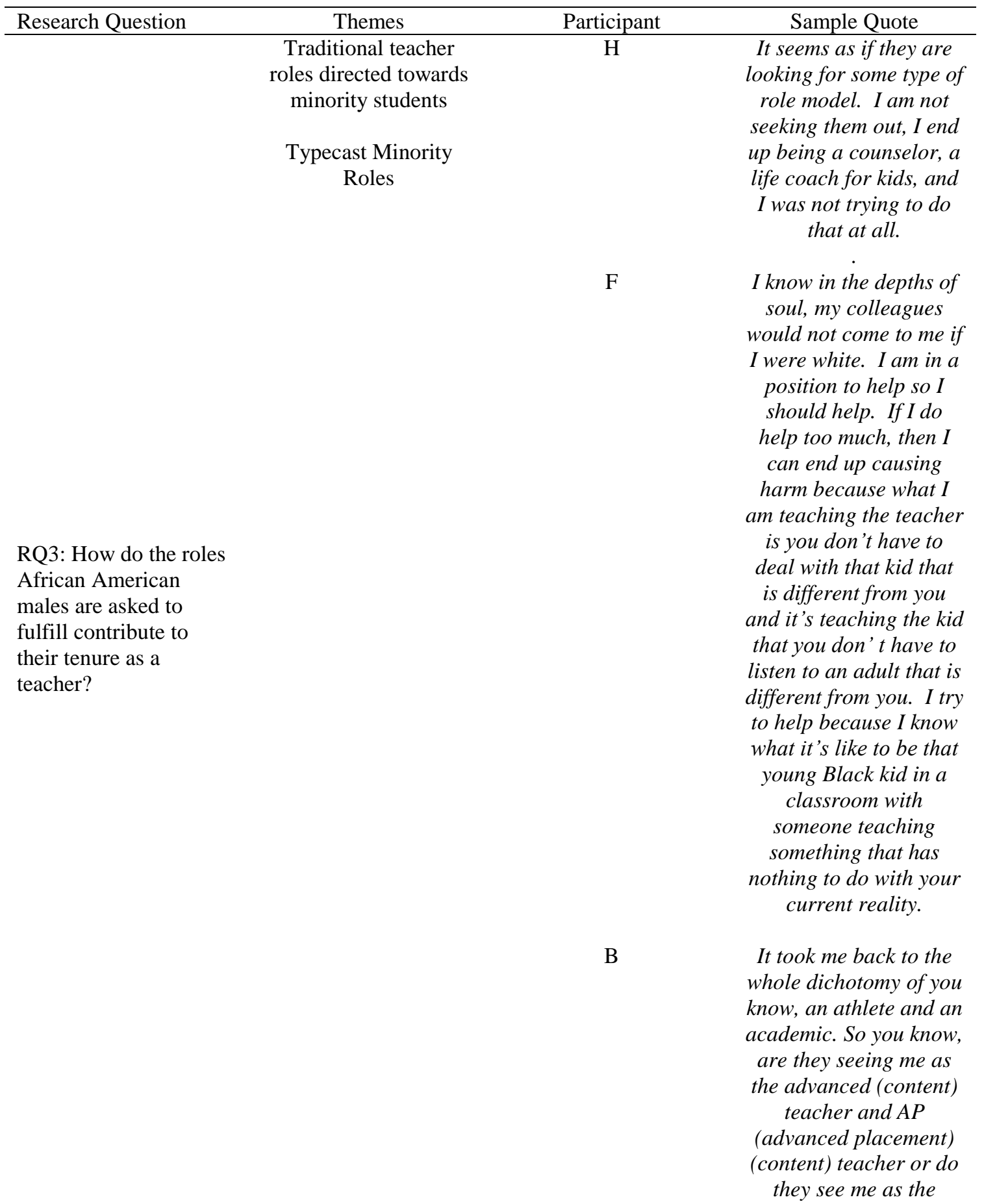




\section{Summary of Roles}

The participants in this study fulfilled many roles outside of their teaching responsibilities. Many of the roles they sought after were designated hired roles within the school including coach and club sponsor. The abundance of their other roles and responsibilities were from non-hired positions that they both sought out and were placed upon them like role model and student advocate. These were roles that most teachers would fill, although these roles were more directed towards the minority students in their buildings. Conversely, many of the positions not sought after were stereotypical, typecast roles that were thrust upon them because there was a gap that needed filled by an African American male. These typecast roles added to their daily teaching responsibilities and did cause some unnecessary stress on some of the participants. None of the participants in this study expressed a desire to leave the teaching field because of the roles they were asked to fulfill. There is an evident fear of losing their job if they do not accept the additional responsibilities however, especially if they are non-tenured.

\section{Summary of Chapter IV}

After a thorough analysis of the interview transcripts using both deductive and inductive coding, the voices of the 10 African American males interviewed in this study were able to shed light on the various themes surrounding the motivations, barriers, and roles of an African American male high school teacher. First-order coding using pattern matching exposed codes that were common to teachers in general. Second-order coding 
using InVivo coding valued the voices and perspectives of the participants as it related to Critical Race Theory. Using the five tenets of CRT, most importantly tenet four (valuing lived experiences); the instances of racism and the microaggressions that these individuals experience on a daily basis were exposed through the interview and coding process. Because of the experiences shared by these men who work in Fayette County Public Schools, a set of implications and recommendations are given later in Chapter V. 


\section{CHAPTER V}

\section{CONCLUSIONS, IMPLICATIONS, AND RECOMMENDATIONS FOR FUTURE}

\section{RESEARCH}

In an effort to explore the situational factors related to the retention of African American male high school teachers, the voices of 10 participants in the Fayette County, Kentucky public school system were utilized. Through the interview process discussed in Chapter IV, the participants gave reason and purpose to the motivations, the barriers, and the roles facing African American male high school teachers in Fayette County and potentially beyond. This chapter presents a summary of the implications, recommendations for future research, and conclusions related to the research questions. The specific research questions guiding this study included:

RQ1. Why are African American males pursuing a career in high school education?

RQ 2. What barriers do African American males face prior to and during their teaching careers?

RQ 3. How do the roles African American males are asked to fulfill contribute to their tenure as a teacher? 


\section{Implications}

\section{The Need to Encourage African American Males to Pursue Teaching Early}

The participants in this study revealed a strong desire to be a mentor and role model for future generations of students. Their aspirations to coach, mentor, pay it forward, and fill that lack of representation for minority students coalesced under the theme of altruism. Altruism as a motivator had been previously discussed in the literature (James, 2002; Lynn, 2002; Lewis, 2007; Martino \& Rezai-Rashti, 2010; Dinkins \& Thomas, 2016) and appeared to be the key determinant for the 10 men in this study as they decided upon their career path. In this study, altruism was reflected in participant's comments that they wanted to support and inspire their students of color. Furthermore, their students of color often gravitated to them for advice, mentoring, and life skills. Finally, the participants' own exposure to the teaching career field early on led them to their path as educators.

A realization that students who are sitting in classrooms are not all experiencing the same things is essential for school districts to recognize. Most of the participants in this study had previous altruistic influencers who guided them towards education. The author of this study suggests 'altruistic influencers' be defined as individuals who demonstrate selflessness, have concern for the well-being of others, and use their ability to put others first as a means to influence those around them to do the same. School districts could learn from these voices by partnering with communities to identify those influencers together, especially African American male educators. African American boys at a young age need exposure to these altruistic influencers because the more they 
see these individuals, the more viable a career like education will become. The implications of this exposure may result in a more diverse teaching field over time.

When the participants were asked why they chose high school specifically over other levels of education, all 10 participants indicated that they had chosen high school because they felt as though they could make more of a difference at that level. Each participant spoke about the connection they could make with that age group and it was evident from the interview process the link they felt with their students, particularly their students of color. This connection was also paramount in their motivation to remain in education. This desire to coach, mentor, support, and pay it forward to a group of students, most of whom came from marginalized backgrounds, speaks to the participant's intrinsic motivation and overall true sense of altruism. As a school or district, recognizing that these African American men can have an impact on their students of color and celebrating that impact, could show those students that teaching can be rewarded and highly regarded. Most male students of color do not see education as a viable and prestigious career choice. Exposure to prestige and recognition early on, with regard to education as a career choice, could change the trajectory of a student's future.

\section{The Need to Address Barriers Preventing African American Males from Pursuing Teaching}

As the participants shared their journeys prior to and during their teaching careers, their voices exposed barriers that had shaped who they were as African American men and educators. Despite the barriers placed in front of them, their motivation to persevere, succeed, and eventually educate, aided in their ability to face the roadblocks they encountered prior to teaching. What was also discovered during this process were the 
barriers they continued to face as current classroom teachers. There was a parallel in some of the barriers the participants faced prior to teaching and the ones they encountered in their current reality.

Many instances of isolation and singling out occurred throughout their adolescence and later on into their time at their respective college or university, although at a much lower rate. This phenomenon of isolation is not a new concept for minority teachers, in particular African American males, as research regarding isolation has been conducted since the early 1990s (Ladson-Billings \& Tate, 1995; Tate, 1997; Morris, 2004; Bristol, 2018). It is vital for school districts to realize that only $2.0 \%$ of the nation's teachers are African American males and as the African American student population continues to increase, the implications for school districts may be dire if they are not forward thinking in their approaches to recruitment, and most importantly retention (Milner, 2018).

The participants in this study focused more on barriers that pertained to their race and skin color, rather than barriers that students in general encounter, such as time management, motivation, and general academic struggles. Schools and districts need to accept that there are seen and unseen barriers that African American boys and men must endure each day. By uncovering the barriers and listening to the individuals who are affected, solutions can be developed. What became evident throughout the interview and coding process was a longing to fit in, be included, and not feel like an outsider within their school setting. The implications of putting race on display so frequently, using it in stereotypical ways, and not being willing to discuss the extreme isolation that results can have implications on the future education system for African American students and 
teachers. By making a concerted effort to build community and empower the voices of the few, that sense of isolation and awareness of their differences may begin to lessen for individuals of color.

In the Fayette County School district where 2973 teachers were employed in the 2019-2020 school year, only 215 of those certified teachers were African American (Kentucky Department of Education, 2020). The implications for the students of the Fayette County School district could be severe if the minority-teaching workforce, particularly, African American males does not increase. Not only will the African American teachers continue to be abundantly aware of their minority status, but this isolation and "silence" as it was described by Participant J, may continue to affect the minority students sitting in the classrooms in Fayette County. The more devalued and ostracized the students feel as previously described, the less likely they are to combat these barriers placed before them and pursue teaching as a viable career choice.

The obstacles that the participants experience during their current job setting may shed light on some hiring and retention practices that may need to change within Fayette County. None of the participants were recruited to teach, no one spoke of Fayette County actively working with their colleges and universities to create a pathway to teaching, and all of the participants spoke of a desire to be heard and valued more as a scholar in their individual school buildings. Many of the participants spoke of the constant changes occurring in their district and the fear that lack of tenure brought. Because of this fear, many of them live in silence, afraid to speak out about issues that matter to them and matter to their students of color. If they remain silent, students of color will continue to be overlooked and stereotyped. Teachers of color will continue to feel devalued and 
ostracized in a community of educators that should hold them in high esteem. As time passes, fewer and fewer students of color will see education as a viable career choice and more and more educators of color will choose to leave the classroom for careers that value them.

\section{The Need to Address Implicit Bias}

During the interview process, the participants all discussed roles they fulfilled in addition to their teaching roles. Many of these roles were not uncommon roles that all teachers find themselves stepping into like club sponsor, sports coach, department lead, etc. These roles were more traditional teacher roles, but there was still a focus on their minority students. As the interview process progressed, the theme of typecast roles emerged when many of these African American men were asked to serve as de facto disciplinarians, credit recovery teachers, and Black role models, roles they were not always comfortable or prepared to take on. These typecast roles are not new themes in the lives of African American male teachers as previously discussed in the literature (Lewis, 2007; Brown, 2012; Bristol \& Mentor, 2018).

The implications of these typecast roles could have devastating effects on the number of African American male teachers that school districts, Fayette County in particular, hire in the future. If there is an evident lack of trust in their abilities to perform as well as, or better than, their white teaching counterparts, then the ramifications of this lack of trust may result in a dwindling teaching force. The individuals are being tasked with being the "Black Superman" for the Black students in the school community and this added level of responsibility and lack of trust in their academic skills could result in teacher burnout (Milner, 2012, Bryan \& Browder, 2013; Bryan \& Ford, 2014, Pabon, 
2016)). Although none of the participants in this study expressed a desire to leave teaching because of these additional roles, many did speak of the added stress it caused and the lack of training they had in regard to those roles.

Not only are there implications for the African American community of teachers with respect to typecast roles, there are also implications for the non-minority teacher workforce. As the non-minority teaching workforce looks to off-load some of their disciplinarian and content recovery roles onto their colleagues of color, they in turn may begin to relinquish some of the control and trust of their own students of color. According to many of the participants in this study, they are seeking "allies" in their workplace, and it is clear to many of them that they are seen as subordinates or the ones who should, "deal with those students" because they look like them. There does not always seem to be this sense of collegial community that many of them desire as educators and there appears to be an assumption on behalf of the schools in Fayette County, that once they are hired, no matter what their color, they are part of the teaching family. These assumptions, however, can have very negative consequences as isolation develops because schools and the district do not appear to even be aware of the silence and implicit bias occurring around them.

\section{Recommendations}

This research could prove advantageous for any school or district that is aiming to tackle the issue of minority teacher recruitment and retention, particularly African American males who are one of the least represented groups in education. This research has allowed me to dive deeper into the motivational factors, barriers and roles that face African American men in teaching within Fayette County. Recommendations for Fayette 
County will be discussed first, followed by recommendations that could prove valuable to school districts across the county.

\section{Recommendations for Fayette County}

As this case study pertains to Fayette County Public Schools, it is important to offer recommendations as it relates to policy and practice. As mentioned previously, the number of African American male high school teachers in Fayette County did not exceed 25 and so there are some necessary changes that need to be made in order to increase that number. By taking the time to address the motivations and barriers to teaching, districts can work to find solutions that will not only benefit the teaching workforce, but the students who are exposed to these educators daily.

It is essential that school districts develop and enact policies related to the recruitment and retention of their minority-teaching workforce. Fayette County does make use of a New Teacher Induction group as mentioned by the participants, but none of the participants felt any type of support in regard to being a minority teacher within Fayette County. Victory is not in recruitment efforts; victory comes in successful, supported and valued African American male teachers who are given the autonomy to express their culture and voice so that they can expose their love for teaching to their African American students. A recommendation to overhaul the New Teacher Induction Program and focus more on addressing educator implicit bias could be a first start in uncovering issues in practice that negatively affect students and teachers of color. Requiring authentic and relative support networks for teachers of color in Fayette County would help to eliminate the isolation and silence that so many of them experience. 
Fayette County employs an Equity Officer and a Director of Minority

Recruitment \& Retention, but not one of the participants spoke of receiving any type of support from either of these two positions. In fact, none of the participants mentioned these positions at all, which would lead me to believe that they did not know the positions either existed or did not have any direct contact with the people responsible. A recommendation of a formal evaluation process involving these two roles is necessary to determine what the purpose of these roles are, their level of interaction with teachers of color, and an audit of their impact on district hiring and retention.

In Fayette County's District Strategic Plan there is a statement related to a 20152016 Audit that revealed the need to hire and retain a more diverse staff to meet the needs of the diverse learners (FCPS Strategic Plan, 2016). The statement reads that they will develop "a system of supports for all staff that allows them to customize their own career path and obtain help along the way" (FCPS Strategic Plan, 2016). There is no mention of specific and measurable efforts that would address the audit results stating that Fayette County needs a more diverse workforce. Moving forward, a recommendation would be to develop a strategic committee comprised of minority teachers, minority administrators, and minority community partners that systemically addresses the recruitment and retention of minority educators for Fayette County. This committee would be tasked with creating measurable goals aimed at addressing the issues brought forth in the audit and since. All of the participants interviewed for this study expressed interest in this endeavor and were willing to help share their stories and expertise in order to move recruitment and retention efforts forward. 
It was apparent that many of the participants did not feel the support from their administrators that they needed. In an effort to bridge the gap between teacher and administrator, a recommendation would be made for hiring principals to undergo intensive training in implicit bias as well as training in interview and evaluation protocols that address the racial microaggressions educators of color experience every day. Administrators could also benefit from focus groups with African American educators that address without any uncertainty, the barriers facing their employees daily. By creating a safe environment for discussion, administrators could begin to make the changes necessary to support and retain a more diverse workforce. Once administrators are trained, a trickle-down effect could take place among the remainder of the school faculty so that everyone can be part of the needed change.

Although none of the participants went into the field of education for recognition, it is important that these individuals are recognized for the work they do and for the lives they impact. It is also essential that students who look like these men are able to see that recognition for teaching is something that occurs consistently and with purpose. African American men may be acknowledged during Black History Month but at what other times are they honored and valued for their contribution to the profession? There are many awards teachers receive each year, but Fayette County could implement awards or recognitions that highlight minority teachers like the, "Minority Teacher of the Year Award." By celebrating the contributions of minority educators, minority students can be given the opportunity to witness positive celebrations around professionals who look like them. 


\section{Recommendations Beyond Fayette County}

As the literature surrounding this subject proves, this is not an issue found within just Fayette County. As the nation's teacher workforce is comprised of only 2\% African American males, there is a need for recommendations that will support these men across the nation and beyond.

Schools and districts should be collaborating with the local colleges and universities in their states. By making efforts to recruit teachers of color early on and collaborating with these institutions, a pipeline for educators can be created. As schools are taking on more high school dual credit opportunities, a recommendation would be made to include teacher education dual credit courses that expose high school students to the career early on. By completing dual credit courses, high school students can earn credits that would reduce the number of courses and cost that they would encounter once they entered college.

If schools and districts are fortunate to be located near an $\mathrm{HBCU}$, then the partnership is even more crucial. The students from these HBCUs should be actively involved in mentoring and supporting young African American students from an early age. These institutions should require community service hours that are to be completed in the school system. For those students who are education majors within the HBCUs, it is imperative that these students be taught how to navigate life as an educator who may be asked to fulfill typecast roles. These institutions may know these roles occur, but do they equip their students with the skills needed to overcome and question these roles?

Although none of the participants in this study discussed testing and licensure as a barrier to becoming a teacher, many do encounter this barrier and are not able to 
overcome it. Recommendations for state waivers that include testing such as the PRAXIS should be implemented to eliminate a racially biased test that prevents many individuals from pursuing education as a career (Dinkins \& Thomas, 2016). States should also explore financial incentives and student loan forgiveness for teachers of color that complete certain years of service in the education industry. Many students across the country do not see education as a lucrative career and so providing financial incentives or loan forgiveness may help reduce the negative impression surrounding pay and prestige.

In an effort to reduce isolation and build community, network groups or social media groups such as Black Male Educators Talk (Twitter) need to be increased. It is paramount that educators of color, in particular African American men feel as though they are a part of a larger community of like-minded individuals who understand the barriers and successes of being a minority teacher. By fostering community and finding solutions to reduce the silence often felt by educators of color, a movement of change and awareness can begin, elevating the voices of those who have been silenced for so long.

\section{Conclusions}

"Because the only way we get better is by having difficult conversations." This statement made by Participant $\mathrm{H}$ encapsulates the heart behind this journey of exploring the often-marginalized voices of African American male high school teachers. This study sought to explore the motivations for teaching, the barriers before and during teaching, and the roles that these men were asked to fulfill, in an attempt to provide clarity to the issue of representation in the high school teaching workforce. Through hours of literature review, interviews, coding, and writing, the hard conversations exposed themes of 
altruism, school and neighborhood pressures, awareness of minority status, isolation, and traditional and typecast roles focused on African American male teachers.

Critical Race Theory served as the theoretical framework through which this study was conducted and played a vital role in developing research questions aimed at exposing the "Culture of Whiteness" that plagues our educational system. CRT allowed these difficult conversations to happen and gave reason to the implications and recommendations that were discussed previously. Minority teachers everyday are experiencing racism and microaggressions, but their silence and isolation often leaves them afraid to broach the subject for fear of retaliation and losing their jobs, especially if they are non-tenured. They also risk continued instances of isolation if they are the ones speaking out.

Future research is necessary in this field by expanding the research population to elementary and middle school African American teachers as well as African American females. Other marginalized and underrepresented populations such as Asian American or Hispanic American teachers could also benefit from a similar study designed to address the teacher shortage in these minority groups. A parallel case study on White teacher's perceptions of their African American teaching colleagues could also provide insight into how these instances of racism and microaggressions are developed.

The ability of the participants in this study to be vulnerable and have those difficult conversations allowed for truth and meaning to emerge, and the findings from this study can be added to prior literature on the void experienced by the American education system concerning African American male teachers. What made this journey even more significant is that it centered on the lack of representation that I encountered in 
my own school and district. As the minority student population grows, it was and remains important that in my district and beyond, efforts are being made to value the voices of the few African American men educating our students and devise solutions to expand minority teacher representation such that is matches the student populations we serve. In the end, "We're supposed to be allies in this journey." 


\section{REFERENCES}

Achinstein, B., Ogawa, R. T., Sexton, D., \& Freitas, C. (2010). Retaining teachers of color: A pressing problem and a potential strategy for "Hard-to-Staff" schools. Review of Educational Research, 80(1), 71-107.

Allen, B. A., \& Boykin, A. W. (1992). African-American children and the educational process: Alleviating cultural discontinuity through prescriptive pedagogy. School Psychology Review, 21(4), 586-596.

Baxter, P., \& Jack, S. (2008). Qualitative case study methodology: Study design and implementation for novice researchers. The Qualitative Report, 13(4), 544-559.

Bianco, M., Leech, N., \& Viesca, K. (2011). Pathways to teaching: African American male teens explore teaching as a career. The Journal of Negro Education, 80(3), 368-383.

Bireda, S., \& Chait, R. (2011). Increasing teacher diversity: Strategies to improve the teacher workforce. Center for American Progress.

Blake, J., Perez, E., \& Darensbourg, A. (2010). Overrepresentation of African American males in exclusionary discipline: The role of school-based mental health professionals in dismantling the school to prison pipeline. Journal of African American Males in Education, 1(3), 196-211. 
Booker, K. (2007). Likeness, comfort, and tolerance: Examining African American adolescents' sense of school belonging. The Urban Review, 39(3), 301-317.

Boston, C., \& Warren, S. R. (2017). The effects of belonging and racial identity on urban American high school students' achievement. Journal of Urban Learning, Teaching and Research, 13, 26-33.

Bristol, T. (2018). To be alone or in a group: An exploration into how the school-based experiences differ for black male teachers across one urban school district. Urban Education, 53(3), 334-354.

Bristol, T. J., \& Mentor, M. (2018). Policing and teaching: The positioning of Black male teachers as agents in the universal carceral apparatus. The Urban Review, 50(2), 218-234.

Brockenbrough, E. (2015). "The discipline stop": Black male teachers and the politics of urban school discipline. Education and Urban Society, 47(5), 499-522.

Brown, A. (2012). On Human kinds and role models: A critical discussion about the African American male teacher. Educational Studies, 48(3), 296-315.

Brown, K. (2014). Teaching in color: a critical race theory in education analysis of the literature on preservice teachers of color and teacher education in the US. Race Ethnicity and Education, 17(3), 326-345.

Brown, J., \& Butty, J. (1999). Factors that influence African American male teachers' educational and career aspirations: Implications for school district recruitment and retention efforts. The Journal of Negro Education, 68(3), 280-292. 
Bryan, N., \& Browder, J. K. (2013). "Are you sure you know what you are doing?" - The lived experiences of an African American male kindergarten teacher. Interdisciplinary Journal of Teaching and Learning, 3(3), 142-158.

Bryan, N., \& Ford, D. Y. (2014). Recruiting and retaining Black male teachers in gifted education. Gifted Child Today, 37(3), 156-161.

Bryan, N., Johnson, L., \& Williams, T. M. (2016). Preparing Black male teachers for the gifted classroom: Recommendations for historically Black colleges and universities (HBCUS). The Journal of Negro Education, 85(4), 489-504.

Bulger, S., Jones, E. M., Taliaferro, A. R., \& Wayda, V. (2015). If you build it, they will come (or not): Going the distance in teacher candidate recruitment. Quest, 67(1), 73-92.

Camera, L. (2018, March 28). States to prioritize hiring teachers of color. (July 13, 2019). Retrieved from https://www.usnews.com/news/education-news/articles/2018-0328/states-to-prioritize-hiring-teachers-of-color.

Carver-Thomas, D. (2018). Diversifying the teaching profession: How to recruit and retain teachers of color. Palo Alto, CA: Learning Policy Institute. (May, 14, 2019) Retrieved from: https://learningpolicyinstitute.org/product/diversifying-teachingprofession.

Cheng, Y. (1993). Profiles of organizational culture and effective schools. School Effectiveness and School Improvement, 4(2), 85-110.

Cheruvu, R., Souto-Manning, M., Lencl, T., \& Chin-Calubaquib, M. (2015). Race, isolation, and exclusion: What early childhood teacher educators need to know 
about the experiences of pre-service teachers of color. The Urban Review, 47(2), 237-265.

Chin, E., \& Young, J. W. (2007). A person-oriented approach to characterizing beginning teachers in alternative certification programs. Educational Researcher, 36(2), 7483.

Christians, C. G., \& Carey, J. W. (1989). The logic and aims of qualitative research. Research methods in mass communication, 354-374.

Clifford, G. J. (1989). Man/women/teacher: Gender, family, and career in American educational history. In D. Warren (Ed.), American teachers: Histories of a profession at work (pp. 293-343). New York: Macmillan.

Cole, B. (1986). The black educator: An endangered species. The Journal of Negro Education, 55(3), 326-334.

Cooper, R., \& Jordan, W. (2003). Cultural issues in comprehensive school reform. Urban Education, 38(4), 380-97.

Constance-Huggins, M. (2012). Critical race theory in social work education. Critical Social Work, 13(2), 1-16.

Coulter, R., \& McNay, M. (1993). Exploring men's experiences as elementary school teachers. Canadian Journal of Education, 18(4), 398-413.

Creswell, J. W., \& Poth, C. N. (2018). Qualitative inquiry \& research design: Choosing among five approaches. Los Angeles: Sage

Crothers, C. (2009). Black Male: Why the mid-south cannot afford to ignore the disparities facing its black men and boys. Jackson, MS: Foundation for the midsouth. 
Cruickshank, V., Pedersen, S., Cooley, P. D., \& Hill, A. (2018). Towards a measure of gender-related challenges faced by male primary teachers. Australian Journal of Education, 62(1), 49-60.

DeCuir-Gunby, J., \& Gunby, N. (2016). Racial microaggressions in the workplace: A critical race analysis of the experiences of African American educators. Urban Education, 51(4), 390-414.

Delgado, R., \& Stefancic, J. (2017). Critical race theory: An introduction (Vol. 20). NYU Press.

Dinkins, E., \& Thomas, K. (2016). Black teachers matter: Qualitative study of factors influencing African American candidates' success in a teacher preparation program. AILACTE Journal, 13, 23-40.

Dixson, A., \& Dingus, J. E. (2008). In search of our mothers' gardens: Black women teachers and professional socialization. Teachers College Record, 110(4), 805837.

Du Bois, W. E. (1935). Does the Negro need separate schools? The Journal of Negro Education, 4(3), 328-335.

Education Commission of the States. (2019, October 21). (September 14, 2020). Retrieved from https://www.ecs.org/wp-content/uploads/State-Info-RequestDiversifying-the-Teacher-Workforce.pdf.

Elliott, V. (2018). Thinking about the coding process in qualitative data analysis. The Qualitative Report, 23(11), 2850-2861.

Fayette County Public Schools. (n.d.). Recruitment and training. (March 10, 2019). Retrieved from https://www.fcps.net/Page/5373. 
Fayette County Schools Strategic Plan 2017-2021. (2016). (February 21, 2021).

Retrieved from

https://www.fcps.net/cms/lib/KY01807169/Centricity/Domain/3899/Strategic\%20

Plan/strategic_plan.pdf.

Ferri, B. \& Connor, D. (2005). Tools of exclusion: Race, disability, and (re)segregated education. Teachers College Record, 107 (3), p. 453-474.

Ford, C. L., \& Airhihenbuwa, C. O. (2010). Critical race theory, race equity, and public health: Toward antiracism praxis. American Journal of Public Health, 100(S1), 30-35.

Foster, M. (1994). The power to know one thing is never the power to know all things: Methodological notes on two studies of Black American teachers. In A. Gitlin (Ed.), Power and method: Political activism and educational research (pp. 129146). Boston: Routledge Kegan Paul.

Francis, B., \& Skelton, C. (2001). Men teachers and the construction of heterosexual masculinity in the classroom. Sex Education, 1(1), 9-21.

Garcia, R. J. (1995). Critical race theory and Proposition 187: The racial politics of immigration law. Chicano-Latino L. Rev., 17, 118.

Gillborn, D. (2006). Critical race theory and education: Racism and anti-racism in educational theory and praxis. Discourse: Studies in the Cultural Politics of Education, 27(1), 11-32.

Goings, R., \& Bianco, M. (2016). Hard to be who you don't see: An exploration of Black male high school students' perspectives on becoming teachers. The Urban Review, 48, 628-646. 
Gold, D., \& Reis, M. (1982). Male teacher effects on young children: A theoretical and empirical consideration. Sex Roles, 8, 493-5.

Gordon, J. (1994). Why students of color are not entering teaching: Reflections from minority teachers. Journal of Teacher Education, 45(5), 346-53.

Graham, A., \& Erwin, K. (2011). "I don't think black men teach because how they get treated as students": High-achieving African American boys' perceptions of teaching as a career option. The Journal of Negro Education, 80(3), 398-416.

Grant, P. (1992). Using special education to destroy black boys. The Negro Educational Review, 63, 17-21.

Gray, L., and Taie, S. (2015). Public school teacher attrition and mobility in the first five years: Results from the first through fifth waves of the 2007-08 beginning teacher longitudinal study (NCES 2015-337). U.S. Department of Education.

Washington, DC: National Center for Education Statistics. (March 3, 2021) Retrieved from http://nces.ed.gov/pubsearch.

Grissom, J., \& Keiser, L. (2011). A supervisor like me: Race, representation, and the satisfaction and turnover decisions of public sector employees. Journal of Policy Analysis and Management, 30(3), 557-580.

Hammond, M. (2002) Why teach? A case study investigating the decision to train to teach ICT. Journal of Education for Teaching, 28(2), 135-148.

Heider, K. L. (2005). Teacher isolation: How mentoring programs can help. Current Issues in Education, 8(14). (May, 14, 2019). Retrieved from http://cie.ed.asu.edu/volume8/number14. 
Howard, T. C., Flennaugh, T. K., \& Terry, C. L., Sr. (2012). Black males, social imagery, and the disruption of pathological identities: Implications for research and teaching. The Journal of Educational Foundations, 26(1/2), 85.

Hoy, W. (1990). Organizational climate and culture: A conceptual analysis of the school workplace. Journal of Educational and Psychological Consultation, 1(2), 149168.

Hudson, M. J., \& Holmes, B. J. (1994). Missing teachers, impaired communities: The unanticipated consequences of Brown v. Board of Education on the African American teaching force at the precollegiate level. The Journal of Negro Education, 63(3), 388-393.

Hutchinson, D. L. (1999). Ignoring the sexualization of race: Heteronormativity, critical race theory and anti-racist politics. Buff. L. Rev., 47, 1.

Hylton, K. (2005). 'Race', sport and leisure: Lessons from critical race theory. Leisure Studies, 24(1), 81-98.

Hylton, K. (2008). 'Race' and sport: critical race theory. Routledge.

Ingersoll, R. \& May, H. (2011). Recruitment, retention and the minority teacher shortage. Consortium for Policy Research in Education. CPRE Research Report \#RR-69.

Ingersoll, R., \& May, H. (2016). Minority teacher recruitment, employment, and retention: 1987 to 2013. Learning Policy Institute, Stanford, CA.

Irvine, J. J., \& Fenwick, L. T. (2011). Teachers and teaching for the new millennium: The role of HBCUs. The Journal of Negro Education, 80(3), 197-208.

James, C. (2002). Achieving desire: A narrative of a Black male teacher. International Journal of Qualitative Studies in Education, 15, 171-186. 
Jay, M. (2009). Race-ing through the school day: African American educators' experiences with race and racism in schools. International Journal of Qualitative Studies in Education, 22(6), 671-685.

Jones, R., Holton, W., \& Joseph, M. (2019). Call me mister: A black male grow your own program. Teacher Education Quarterly, 46(1), 55-68.

Kaiser, K. (2009). Protecting respondent confidentiality in qualitative research. Qualitative Health Research, 19(11), 1632-41.

Kanter, R. (1977). Some effects of proportions on group life: Skewed sex ratios and responses to token women. American Journal of Sociology, 82(5), 965-990.

Kellow, J. T., \& Jones, B. D. (2008). The effects of stereotypes on the achievement gap: Reexamining the academic performance of African American high school students. Journal of Black Psychology, 34(1), 94-120.

Kentucky Department of Education School Report Card. (2020). (February 21, 2021). Retrieved from https://www.kyschoolreportcard.com/organization/5559/school_overview/faculty _staff_community/faculty_counts?year=2020.

Kentucky Department of Education. (2018, May 16). School report card. (December 4, 2019). Retrieved from https://applications.education.ky.gov/src/LearningEnvironmentByDistrict.aspx.

King, S. (1993). Why did we choose teaching careers and what will enable us to stay?: Insights from one cohort of the African American teaching pool. The Journal of Negro Education, 62(4), 475-492. 
Kirk, M. (2017, August 16). The repercussions of the Black teacher shortage. Retrieved October 10, 2018, from https://www.citylab.com/equity/2017/08/black-taechershortage/536757/

Kohli, R. (2008). Breaking the cycle of racism in the classroom: Critical race reflections from future teachers of color. Teacher Education Quarterly, 35(4), 177-188.

Kohli, R. (2018). Behind school doors: The impact of hostile racial climates on urban teachers of color. Urban Education, 53(3), 307-333.

Kokka, K. (2016). Urban teacher longevity: What keeps teachers of color in one underresourced urban school? Teaching and Teacher Education. 59, 169-179.

Kolivoski, K. M., Weaver, A., \& Constance-Huggins, M. (2014). Critical race theory: Opportunities for application in social work practice and policy. Families in Society, 95(4), 269-276.

Korstjens, I., \& Moser, A. (2018). Series: Practical guidance to qualitative research. Part 4: Trustworthiness and publishing. European Journal of General Practice, 24(1), $120-124$.

Ladson-Billings, G., \& Tate, B. (1995). Toward a critical race theory of education. Teachers College Record, 97(1), 47-67.

Lapayese, Y. V. (2007). Understanding and undermining the racio-economic agenda of No Child Left Behind: Using critical race methodology to investigate the labor of bilingual teachers. Race Ethnicity and Education, 10, 309-321.

Ledesma, M. C., \& Calderón, D. (2015). Critical race theory in education: A review of past literature and a look to the future. Qualitative Inquiry, 21(3), 206-222. 
Lewis, C. (2007). African American male teachers in public schools: An examination of three urban school districts. Teachers College Record, 108, 224-245.

Long, J., \& Hylton, K. (2002). Shades of white: An examination of whiteness in sport. Leisure studies, 21(2), 87-103.

López, G. R. (2003). The (racially neutral) politics of education: A critical race theory perspective. Educational Administration Quarterly, 39(1), 68-94.

Losen, D. \& Orfield, G. (2002). Racial inequity in special education. Cambridge: Harvard Education Publishing Group.

Lynn, M. (2002). Critical race theory and the perspectives of black men teachers in the Los Angeles public schools. Equity \& Excellence in Education, 35(2), 119-30.

Lynn, M. (2006). Education for the community: Exploring the culturally relevant practices of black male teachers. Teachers College Record, 108(12), 2497-2522.

Mabokela, R., \& Madsen, J. (2003). Crossing boundaries: African American teachers in suburban schools. Comparative Education Review, 47(1), 90-111.

Madkins, T. (2011). The black teacher shortage: A literature review of historical and contemporary trends. The Journal of Negro Education, 80(3), 417-427.

Manuel, J., \& Hughes, J. (2006). It has always been my dream: Exploring pre-service teachers' motivations for choosing to teach. Teacher Development, 10(1), 5-24,

Martino, W. J. (2015). The limits of role modeling as a basis for critical multicultural education: The case of Black male teachers in urban schools. Multicultural Education Review, 7(1-2), 59-84.

Martino, W., \& Berrill, D. (2003). Boys, schooling and masculinities: Interrogating the "right" way to educate boys. Education Review, 55(2), 99-117. 
Martino, W., \& Rezai-Rashti, G. (2010). Male teacher shortage: Black teachers’ perspectives. Gender and Education, 22(3), 247-262.

Matias, C. E., Viesca, K. M., Garrison-Wade, D. F., Tandon, M., \& Galindo, R. (2014). "What is critical whiteness doing in OUR nice field like critical race theory?" Applying CRT and CWS to understand the white imaginations of white teacher candidates. Equity \& Excellence in Education, 47(3), 289-304.

Meyer, C. B. (2001). A case in case study methodology. Field Methods, 13(4), 329-352.

Miles, M. B., Huberman, A. M., \& Saldaña, J. (2014). Qualitative data analysis: A methods sourcebook. Los Angeles: Sage.

Milner, H. R. (2007). Race, culture, and researcher positionality: Working through dangers seen, unseen, and unforeseen. Educational Researcher, 36(7), 388-400.

Milner, H. R. (2012). Challenging negative perceptions of black teachers. Educational Foundations, 26(1-2), 27-46.

Milner, H. R. (2018). Confronting inequity / the black male teacher gap. Educational Leadership, 75(8), 90-91.

Milner, H. R., \& Laughter, J. C. (2015). But good intentions are not enough: Preparing teachers to center race and poverty. The Urban Review, 47(2), 341-363.

Morris, J. E. (2004). Can anything good come from Nazareth? Race, class, and African American schooling and community in the urban south and Midwest. American Educational Research Journal, 41(1), 69-112.

Morris, V. G., \& Morris, C. L. (2013). A call for African American male teachers: The supermen expected to solve the problems of low-performing schools. In C. W. Lewis \& I. A. Toldson (Eds.), Black male teachers: Diversifying the United 
States’ Teacher Workforce (pp. 151-165). Bingley: Emerald Group Publishing. Morse, J. M., Stern, P. N., Corbin, J., Bowers, B., Charmaz, K., \& Clarke, A. E. (2016). Developing grounded theory: The second generation. Routledge.

National Center Education Statistics. (2020 Data). Retrieved May 22, 2020, from https://nces.ed.gov/

National Center for Education Statistics. (2019, February). Retrieved from https://nces.ed.gov/programs/raceindicators/indicator_rbb.asp.

Okezie, C. E. (2018). The Marygrove College griot program: A grow your own program for African American male teachers. The Urban Review, 50(2), 235-246.

Pabon, A. (2016). Waiting for black superman: A look at a problematic assumption. Urban Education, 51(8), 915-939.

Pabon, A. J. M., Anderson, N. S., \& Kharem, H. (2011). Minding the gap: Cultivating Black male teachers in a time of crisis in urban schools. The Journal of Negro Education, 358-367.

Parker, L., \& Lynn, M. (2002). What's race got to do with it? Critical race theory's conflicts with and connections to qualitative research methodology and epistemology. Qualitative Inquiry, 8(1), 7-22.

Pittman, C. T. (2012). Racial microaggressions: The narratives of African American faculty at a predominantly white university. Journal of Negro Education, 81(1), 82-92.

Priyadharshini, E., \& Robinson-Pant, A. (2003) The attractions of teaching: an investigation into why people change careers to teach. Journal of Education for Teaching, 29(2), 96-112. 
Qu, S. Q., \& Dumay, J. (2011). The qualitative research interview. Qualitative Research in Accounting \& Management, 8(3), 238-264.

Razack, N., \& Jeffery, D. (2002). Critical race discourse and tenets for social work. Canadian Social Work Review/Revue canadienne de service social, 257271.

Rice, C. J., \& Goessling, D. P. (2005). Recruiting and retaining male special education teachers. Remedial and Special Education, 26, 347-356.

Saldaña J. (2016). The coding manual for qualitative researchers (3rd ed.). Los Angeles: Sage.

Scott, L. A. (2016). Where are all the black male special education teachers? Perspectives on Urban Education, 13(1), 42-48.

Sexton, P. (1969). The feminized male: Classrooms, white collars, \& the decline of manli- ness. New York: Random House.

Sleeter, C. E. (2017). Critical race theory and the whiteness of teacher education. Urban Education, 52(2), 155-169.

Smith, W., Hung, M., \& Franklin, J. (2011). Racial battle fatigue and the miseducation of black men: Racial microaggressions, societal problems, and environmental stress. The Journal of Negro Education, 80(1), 63-82.

Solano-Flores, G., \& Nelson-Barber, S. (2001). On the cultural validity of science assessments. Journal of Research in Science Teaching, 38, 553-573.

Solorzano, D. G., \& Bernal, D. D. (2001). Examining transformational resistance through a critical race and Latcrit theory framework: Chicana and Chicano students in an urban context. Urban Education, 36(3), 308-342. 
Solorzano, D., \& Yosso, T. (2002). Critical race methodology: Counter-storytelling as an analytical framework for education research. Qualitative Inquiry, 8(1), 23-44.

Stake, R. E. (1995). The art of case study research. Sage.

Stanfield, J. H., II. (1999). Slipping through the front door: Relevant social scientific evaluation in the people of color century. American Journal of Evaluation, 20, $415-431$

Stevens, D. M., Brydon-Miller, M., \& Raider-Roth, M. (2016). Structured ethical reflection in practitioner inquiry: Theory, pedagogy, and practice. The Educational Forum, 80(4), 430-443.

Sue, D. W. (2004). Whiteness and ethnocentric monoculturalism: Making the "invisible" visible. American Psychologist, 59, 761-769.

Sue, D. W., Capodilupo, C. M., Torino, G. C., Bucceri, J. M., Holder, A. M. B., Nadal, K. L., \& Esquilin, M. (2007). Racial microaggressions in everyday life: Implications for clinical practice. American Psychologist, 62(4), 271-286.

Sue, D. W., Nadal, K. L., Capodilupo, C. M., Lin, A. I., Torino, G. C., \& Rivera, D. P. (2008). Racial microaggressions against black Americans: Implications for counseling. Journal of Counseling \& Development, 86(3), 330-338.

Sun, M. (2018). Black teachers' retention and transfer patterns in North Carolina: How do patterns vary by teacher effectiveness, subject, and school conditions? AERA Open, 4(3), 1-23.

Suri, H. (2011). Purposeful sampling in qualitative research synthesis. Qualitative Research Journal, 11(2), 63-75. 
Szecsi, T., \& Spillman, C. (2012). Unheard voices of minority teacher candidates in a teacher education program. Multicultural Education, 19(2), 24-29.

Tate, W. F. (1997). Critical race theory and education: History, theory, and implications. In M. Apple (Ed.), Review of Research in Education (Vol. 22, pp. 195-247). Washington, DC: American Educational Research Association.

Taylor, E., Gillborn, D., \& Ladson-Billings, G. (2009). Foundations of critical race theory in education. New York: Routledge.

Thomas, K. M., Dinkins, E., \& Hazelwood, I. (2018). Racial microaggressions: Stories of Black candidates in a teacher preparation program at a predominately White institution. AILACTE Journal, 15(1), 77-92.

Thomas, S. B., Quinn, S. C., Butler, J., Fryer, C. S., \& Garza, M. A. (2011). Toward a fourth generation of disparities research to achieve health equity. Annual Review of Public Health, 32, 399-416.

Underwood, K., Smith, D., Johnson-Lutz, H., Taylor, J., \& Roberts, J. M. (2019). Having our say: Examining the career trajectories of Black male educators in P-12 education. National Network of State Teachers of the Year.

United States Department of Education. (2016). The state of racial diversity in the educator workforce. https://www2.ed.gov/rschstat/eval/highered/racialdiversity/state-racial-diversity-workforce.pdf.

Valencia, R. R. (2010). Dismantling contemporary deficit thinking: Educational thought and practice. New York, NY: Routledge. 
Valle-Riestra, D. M., Shealey, M. W., \& Cramer, E. D. (2011). Recruiting and retaining culturally diverse special educators. Interdisciplinary Journal of Teaching and Learning, 1(2), 68-87.

Vavrus, F., \& Cole, K. M. (2002). "I didn't do nothin"”: The discursive construction of school suspension. Urban Review, 34, 87-111.

Vegas E., Murnane, R., \& Willett, J. (2001). From high school to teaching: Many steps. Who makes it? Teachers College Record, 103, 427-449.

Villegas, A. M., Strom, K., \& Lucas, T. (2012). Closing the racial/ethnic gap between students of color and their teachers: An elusive goal. Equity \& Excellence in Education, 45(2), 283-301.

Wiersma, W. (2000). Research Methods in Education: An Introduction. Boston, MA. Allyn and Bacon.

Wiest, L. R. (2003). The current status of male teachers of young children. The Educational Forum, 68, 62-70.

Yosso, T. (2005). Whose culture has capital? A critical race theory discussion of community cultural wealth. Race, Ethnicity and Education, 8, 69-92.

Yin, R. K. (1994). Case study research design and methods (2nd ed., Vol. 5, Applied social research methods). Sage Publications.

Yin, R. K. (2018). Case study research and applications: design and methods (6th ed.). Los Angeles: Sage. 


\section{Appendix A}

\section{Informed Consent}

\section{BLACK MEN WANTED: AN INSTRUMENTAL CASE STUDY EXPLORING THE SITUATIONAL FACTORS RELATED TO THE RETENTION OF AFRICAN AMERICAN MALE HIGH SCHOOL TEACHERS}

\section{Summary Information}

The purpose of this study is to find out why African American men are choosing to be high school teachers, what obstacles they are keeping them from teaching and what roles they play in their schools other than teacher. Participants in this study will find it useful to share their stories of how they became a teacher and how they might have overcome obstacles to get to where they are today.

Participants in this study will be asked to participate in a one-hour interview that will occur face to face and one on one. After the interview is complete, participants may be asked to participate in a phone or email conversation to provide any clarification to the interview questions. A copy of the interview will be submitted to the participants so that they can check it for accuracy. Interviews will be scheduled at the convenience of the participant and in a location selected by the participant as long as the location is free of distractions.

There are risks to this study that are described in this document. Risks may include feeling uncomfortable answering some of the questions during the interview as well as being identified by some of the information that is provided in the study by other teachers in Fayette County although that risk is minimal.

If you are interested in learning more about this study, please continue to read below.

\section{Introduction and Background Information}

You are invited to take part in a research study because you have been identified as an African American male who teaches at the high school level in Fayette County. The study is being conducted under the direction of Denise Cumberland, $\mathrm{PhD}$ of The College of Education and Human Development at the University of Louisville. 


\section{Purpose}

The purpose of this study is to explore the reasons African American males choose high school teaching and what barriers they face prior to and once they enter the classroom. This study also attempts to explore the roles they are asked to fulfill in their work setting outside of their regular teaching responsibilities, and if those roles contribute to their retention.

\section{Procedures}

In this study, you will be asked to schedule a time with the principal investigator to sit for a semi-structured interview that will last no longer than one hour. The interview site will be chosen by you but will take place in a quiet environment to limit distractions during the interview. The purpose of the interview questions will serve as the basis for information pertaining to why you chose high school education, what barriers you faced prior to and during your teaching career and what roles you may be asked to fulfill in your current role as a teacher. Interviews will be recorded with both video and audio equipment to ensure reliability and accurateness of the interview. Preexisting data related to your name, location of your employment, and designation as an African American male will already be known. The overall study duration including consent forms, interviews, and follow up questions should last no longer, than one month but your time commitment to this study should be minimal. During the interview process, you may decline to answer any question that may make you uncomfortable.

Results of the overall research study will be shared with you after the completion of the doctoral defense. Results will be shared with you in person or through email

Your data will be stored and shared for future research without additional informed consent if identifiable private information, such as your name are removed. If identifying information is removed from your data, the data may be used for future research studies or given to another investigator for future research studies without additional consent from you.

\section{Potential Risks}

There are no foreseeable risks other than possible discomfort in answering personal questions and the potential for identification by other teachers in Fayette County who may read this research study. There may also be unforeseen risks.

The possible benefits of this study include being able to share your story and personal recommendations on how to increase and retain African American male teachers.

The information collected may not benefit you directly; however, the information may be helpful to others. 


\section{Alternatives}

Instead of taking part in this study, you could choose to not participate in this study.

\section{Payment}

You will not be paid for your time, inconvenience, or expenses while you are in this study.

\section{Confidentiality}

Total privacy cannot be guaranteed. We will protect your privacy to the extent permitted by law. If the results from this study are published, your name will not be made public. Once your information leaves our institution, we cannot promise that others will keep it private.

Your information may be shared with the following:

- The sponsor and others hired by the sponsor to oversee the research

- Organizations that provide funding at any time for the conduct of the research.

- The University of Louisville Institutional Review Board, Human Subjects Protection Program Office, Privacy Office, others involved in research administration and research and legal compliance at the University, and others contracted by the University for ensuring human participants safety or research and legal compliance

- The local research team

- Applicable government agencies, such as:

○ Office for Human Research Protections

\section{Security}

The data collected about you will be kept private and secure by password-protected computer and secured server with limited access.

\section{Voluntary Participation}

Taking part in this study is voluntary. You may choose not to take part at all. If you decide not to be in this study, you will not be penalized or lose any benefits for which you qualify. If you decide to be in this study, you may change your mind and stop taking part at any time. If you decide to stop taking part, you will not be penalized or lose any benefits for which you qualify. You will be told about any new information learned during the study that could affect your decision to continue in the study. 


\section{Research Participant's Rights}

If you have any questions about your rights as a research participant, you may call the Human Subjects Protection Program Office at (502) 852-5188. You may discuss any questions about your rights as a research participant, in private, with a member of the Institutional Review Board (IRB). You may also call this number if you have other questions about the research, and you cannot reach the study doctor, or want to talk to someone else. The IRB is an independent committee made up of people from the University community, staff of the institutions, as well as people from the community not connected with these institutions. The IRB has approved the participation of human participants in this research study.

\section{Questions, Concerns and Complaints}

If you have any questions about the research study, please contact Christopher Flores at 859-229-7115.

If you have concerns or complaints about the research or research staff and you do not wish to give your name, you may call the toll free number 1-877-852-1167. This is a 24hour hot line answered by people who do not work at the University of Louisville.

\section{Acknowledgment and Signatures}

This document tells you what will happen during the study if you choose to take part. Your signature and date indicates that this study has been explained to you, that your questions have been answered, and that you agree to take part in the study. You are not giving up any legal rights to which you are entitled by signing this informed consent document though you are providing your authorization as outlined in this informed consent document. You will be given a copy of this consent form to keep for your records.

$\overline{\text { Participant Name (Please Print) } \quad \text { Signature of Participant } \quad \text { Date Signed }}$

Printed Name of Investigator(s) (PI, Sub-I, or Co-I)

Signature of Investigator(s) (PI, Sub-I, or Co-I)

Date(s) Signed

Phone number for participants to call for questions: (502) 609-3504 or (859) 229-7115 
Principal Investigator: Denise Cumberland, PhD, Department of Educational Leadership, Evaluation and Organizational Development Room 338B - University of Louisville College of Education and Human Development, (502) 852-1645.

Co-Investigator: Christopher Flores, Doctor of Education, (859) 229-7115, University of Louisville College of Education and Human Development, 721 Riverwood Ln, Lexington, KY 40514.

Site(s) where study is to be conducted: Fayette County, Kentucky. 


\section{Appendix B}

\section{Participant Semi-Structured Interview Questions}

1. What and/or who motivated you to choose education as a career path and why?

2. What brought you to high school education instead of other levels of education (elementary, middle school, or university level)?

3. Explain what struggles, if any, that you experienced as a student during your K-12 education?

4. Explain what struggles, if any, did you experience as a university student?

5. What do you attribute the struggles you may have had during your K-12 educational experience to? Please explain.

6. Explain the process for being hired for your first teaching job in Fayette County. Were you recruited, did you find the job on your own, or did you know someone already in the building?

7. Describe your first year of teaching in Fayette County. What supports did you receive if any as a new teacher in your building?

8. What barriers, if any, have you experienced in your current job setting? Please explain.

9. What other roles do you fulfill outside of classroom teacher within your building and were these roles assigned to you or did you seek these roles out? Explain. 
10. Have doors been opened for you professionally since becoming a teacher in Fayette County? If yes or no, what do you attribute that to and why?

11. There are currently just under 300 African American teachers in Fayette County (male and female included at all levels of teaching). Does that number surprise you? Why or why not?

12. What suggestions do you have, if any, as to how Fayette County could recruit and retain more African American males as teachers if you see that as a need?

13. Overall, what do you think is the biggest barrier that African American males must overcome in the pursuit of obtaining and retaining a teaching job?

14. What is your birthdate? 


\section{Appendix C}

\section{Initial Email Participant Letter}

Dear

My name is Christopher Flores and I am inviting you to participate in a study entitled Black Men Wanted: An Instrumental Case Study exploring the situational factors related to the retention of African American male high school teachers". So that you are aware, this study is being conducted in partial fulfillment of the Ed.D in Educational Leadership and Organizational Development through The University of Louisville. I will be serving as the Co-investigator in this study (859-229-7115, Christopher.flores@ fayette.kyschools or chrisflores_uk@yahoo.com). My Doctoral Committee Chair and Principal Investigator is Dr. Denise Cumberland (502-609-3504, denise.cumberland@louisville.edu). You are being invited to volunteer as a participant because you are an African American male teacher in a Fayette County high school/program and I believe that you could offer great insight into the life of a minority teacher. If you choose to participate in this study, it will include an interview conversation that should last approximately 60 minutes that will be conducted after school hours in a location that works best for you as long as the environment is free from distractions. This conversation will be recorded by a tape recorder, a computer audio recorder, and I will also be taking written notes. A follow-up conversation may occur via phone or e-mail of no more than thirty (30) minutes, which will allow me to check for the accuracy and clarification of my notes after reviewing the transcripts of our first meeting. 
Email may also be used to contact you throughout the study, however, clarification of information, as follow-up, will be done by telephone, unless you have a private email account that you are willing to use for this purpose. Participation in this study is voluntary and there is no penalty for not participating or for withdrawing from the study. If you agree to participate in this study, your identity will be kept strictly confidential. Your name and school will not appear in the study. Your stories will be referenced by a pseudo name. All transcripts will be kept on a password-protected computer as well as an external hard drive that will be kept in a locked safe in the Co-Investigator's home. If you decide you are interested in learning more about participating in this study, please respond to this email. I will follow up by mailing you an informed consent form to review. Thereafter, I will e-mail or telephone you to review the next steps and schedule a time for us to go over the consent document together. If you decide to participate, we will then proceed to the interview. If you have any questions, you may contact either me or Dr. Cumberland as indicated above. Thank you for considering possible participation in this study.

Respectfully, Christopher Flores 


\section{Appendix D}

\section{Structured Ethical Reflection}

\begin{tabular}{|c|c|c|c|c|c|c|c|c|}
\hline Values & $\begin{array}{l}\text { Developing } \\
\text { Partnerships }\end{array}$ & $\begin{array}{l}\text { Constructing } \\
\text { Research } \\
\text { Question }\end{array}$ & $\begin{array}{c}\text { Planning } \\
\text { Project/Action }\end{array}$ & $\begin{array}{l}\text { Recruiting } \\
\text { Participants }\end{array}$ & $\begin{array}{l}\text { Collecting } \\
\text { Data/ Taking } \\
\text { Action }\end{array}$ & $\begin{array}{l}\text { Analyzing } \\
\text { Data/ } \\
\text { Evaluating } \\
\text { Action }\end{array}$ & $\begin{array}{l}\text { Member } \\
\text { Checking }\end{array}$ & $\begin{array}{c}\text { Going Public } \\
\text { (Presentation \& } \\
\text { Publication) }\end{array}$ \\
\hline Courage & $\begin{array}{l}\text { Finding } \\
\text { partners who } \\
\text { will share their } \\
\text { story }\end{array}$ & $\begin{array}{l}\text { Remembering } \\
\text { that the questions } \\
\text { may take } \\
\text { courage to ask }\end{array}$ & $\begin{array}{l}\text { Creating a plan } \\
\text { that will take the } \\
\text { researcher out of } \\
\text { his comfort zone }\end{array}$ & $\begin{array}{l}\text { Instilling courage } \\
\text { in the } \\
\text { participants that } \\
\text { are willing to } \\
\text { share }\end{array}$ & $\begin{array}{l}\text { Undertaking } \\
\text { the daunting } \\
\text { task of } \\
\text { collecting } \\
\text { data. }\end{array}$ & $\begin{array}{l}\text { Accepting that } \\
\text { the data may } \\
\text { not align with } \\
\text { my beliefs or } \\
\text { thoughts }\end{array}$ & $\begin{array}{l}\text { Checking with } \\
\text { participants to } \\
\text { ensure that their } \\
\text { story has been } \\
\text { told }\end{array}$ & $\begin{array}{l}\text { Accepting that } \\
\text { my research } \\
\text { may not be } \\
\text { accepted by } \\
\text { others }\end{array}$ \\
\hline Equality & $\begin{array}{l}\text { Seeking out a } \\
\text { variety of } \\
\text { partnerships }\end{array}$ & $\begin{array}{l}\text { Creating } \\
\text { questions that } \\
\text { promote equality } \\
\text { amongst all } \\
\text { groups }\end{array}$ & $\begin{array}{l}\text { Recognizing } \\
\text { equity barriers in } \\
\text { the planning } \\
\text { phases }\end{array}$ & $\begin{array}{l}\text { Choosing } \\
\text { participants from } \\
\text { a variety of } \\
\text { perspectives and } \\
\text { backgrounds }\end{array}$ & $\begin{array}{l}\text { Including data } \\
\text { and thoughts } \\
\text { from all } \\
\text { aspects of the } \\
\text { research }\end{array}$ & $\begin{array}{l}\text { Analyzing data } \\
\text { from all } \\
\text { perspectives to } \\
\text { ensure equality }\end{array}$ & $\begin{array}{l}\text { Checking the } \\
\text { interpretation } \\
\text { of the research } \\
\text { with } \\
\text { participants }\end{array}$ & $\begin{array}{l}\text { Promoting } \\
\text { equality and } \\
\text { diversity } \\
\text { among the } \\
\text { public and } \\
\text { community }\end{array}$ \\
\hline Leadership & $\begin{array}{l}\text { Promoting and } \\
\text { elevating the } \\
\text { partnership }\end{array}$ & $\begin{array}{l}\text { Finding } \\
\text { questions that } \\
\text { will lead the } \\
\text { research }\end{array}$ & $\begin{array}{l}\text { Creating my own } \\
\text { action protocol } \\
\text { instead of relying } \\
\text { on others }\end{array}$ & $\begin{array}{l}\text { Encouraging } \\
\text { participants to } \\
\text { take on new roles }\end{array}$ & $\begin{array}{l}\text { Finding new } \\
\text { ways to collect } \\
\text { data }\end{array}$ & $\begin{array}{l}\text { Welcoming } \\
\text { feedback and } \\
\text { help from } \\
\text { leaders in the } \\
\text { industry }\end{array}$ & $\begin{array}{l}\text { Ensuring the } \\
\text { participants are } \\
\text { ready to share } \\
\text { and lead }\end{array}$ & $\begin{array}{l}\text { Publishing and } \\
\text { becoming a } \\
\text { leader in the } \\
\text { field }\end{array}$ \\
\hline Opportunity & $\begin{array}{l}\text { Finding } \\
\text { partners who } \\
\text { have not been } \\
\text { highlighted }\end{array}$ & $\begin{array}{l}\text { Writing research } \\
\text { questions that } \\
\text { give opportunity } \\
\text { for a strong } \\
\text { voice }\end{array}$ & $\begin{array}{l}\text { Taking the time } \\
\text { and space to plan } \\
\text { when it presents } \\
\text { itself }\end{array}$ & $\begin{array}{l}\text { Giving my } \\
\text { participants a } \\
\text { chance to share } \\
\text { their story }\end{array}$ & $\begin{array}{l}\text { Seeking data } \\
\text { that has not } \\
\text { been } \\
\text { discovered }\end{array}$ & $\begin{array}{l}\text { Being open to } \\
\text { new } \\
\text { information } \\
\text { found in my } \\
\text { research }\end{array}$ & $\begin{array}{l}\text { Finding ways to } \\
\text { continue to } \\
\text { include the } \\
\text { participants in } \\
\text { the process }\end{array}$ & $\begin{array}{l}\text { Seeking out } \\
\text { ways to share } \\
\text { my research } \\
\text { with schools } \\
\text { and districts }\end{array}$ \\
\hline Respect & $\begin{array}{l}\text { Being aware of } \\
\text { the } \\
\text { responsibility } \\
\text { on the partners }\end{array}$ & $\begin{array}{l}\text { Creating } \\
\text { questions that } \\
\text { will promote and } \\
\text { help the } \\
\text { participants }\end{array}$ & $\begin{array}{l}\text { Being aware of } \\
\text { my timeline and } \\
\text { the process }\end{array}$ & $\begin{array}{l}\text { Understanding } \\
\text { that participants } \\
\text { may not have the } \\
\text { same } \\
\text { perspectives as } \\
\text { me }\end{array}$ & $\begin{array}{l}\text { Finding the } \\
\text { right time and } \\
\text { space to } \\
\text { collect data } \\
\text { and allowing } \\
\text { for participant } \\
\text { input }\end{array}$ & $\begin{array}{l}\text { Valuing the } \\
\text { process of } \\
\text { analyzing data } \\
\text { even when it's } \\
\text { difficult }\end{array}$ & $\begin{array}{l}\text { Finding time } \\
\text { that works for } \\
\text { the participants } \\
\text { to continue to } \\
\text { be a part of the } \\
\text { process }\end{array}$ & $\begin{array}{l}\text { Working to } \\
\text { understand my } \\
\text { audience and } \\
\text { their } \\
\text { viewpoints on } \\
\text { my topic }\end{array}$ \\
\hline $\begin{array}{c}\text { Social } \\
\text { Responsibility }\end{array}$ & $\begin{array}{l}\text { Ensuring the } \\
\text { partners benefit } \\
\text { society }\end{array}$ & $\begin{array}{l}\text { Accepting the } \\
\text { challenge to } \\
\text { create questions } \\
\text { that make people } \\
\text { uncomfortable }\end{array}$ & $\begin{array}{l}\text { Understanding } \\
\text { the impact of my } \\
\text { research plan on } \\
\text { schools }\end{array}$ & $\begin{array}{l}\text { Finding the } \\
\text { participants who } \\
\text { don't normally } \\
\text { have an } \\
\text { opportunity to } \\
\text { share }\end{array}$ & $\begin{array}{l}\text { Finding a way } \\
\text { to collect data } \\
\text { that promotes } \\
\text { social justice }\end{array}$ & $\begin{array}{l}\text { Making sure to } \\
\text { report all the } \\
\text { data accurately } \\
\text { and } \\
\text { appropriately }\end{array}$ & $\begin{array}{l}\text { Checking often } \\
\text { with the } \\
\text { participants to } \\
\text { promote input. }\end{array}$ & $\begin{array}{l}\text { Realizing that I } \\
\text { have a social } \\
\text { and moral } \\
\text { obligation to } \\
\text { present my } \\
\text { findings. }\end{array}$ \\
\hline
\end{tabular}




\section{CURRICULUM VITA}

NAME: $\quad$ Christopher K. Flores

ADDRESS: 721 Riverwood Ln.

Lexington, KY 40514

DOB: $\quad$ DeRidder, Louisiana - December 11, 1982

ADMINISTRATIVE \& TEACHING EXPERIENCE:

ADMINISTRATIVE DEAN/PGES COACH - FAYETTE COUNTY STEAM ACADEMY

Lexington, Kentucky - August 2013 to current

One of the founding members of STEAM Academy and have been instrumental in changing the face of education in Lexington.

Supervises the BCTC Dual Credit STEAM Campus and creates the master schedule for that campus

* In charge of all discipline in the building

* Responsible for all buildings and grounds needs

* Supervises and evaluates teachers and classified staff

* Assists in creating the master schedule for the school

* Maintains STEAM's partnership with the University of Kentucky and other Dual Credit Partners

* Responsible for all transportation and field trips

* Responsible for the school report card and data

* Handles all other duties as assigned by the principal

SPANISH TEACHER - PAUL LAURENCE DUNBAR HIGH SCHOOL

Lexington, Kentucky - August 2006 to May 2013

* Design and implement lesson plans for students of Spanish I, II, and III. 
Adapt and accommodate materials and lessons for students with special needs. Develop and implement teaching strategies including direct teaching, small groups, paired work, student led lessons and independent work time.

* Collaborate with department to create effective lessons and assessments. EDUCATION:

DOCTORATE DEGREE - University of Louisville

Educational Leadership and Organizational Development January 2018-May 2021

MASTER'S DEGREE - EASTERN KENTUCKY UNIVERSITY

Educational Administration May 2010-December $2011 \quad$ GPA: 4.0/4.0

MASTER'S DEGREE - GEORGETOWN COLLEGE

Master of Arts in Education June 2005-August $2006 \quad$ GPA: 4.0/4.0

BACHELOR'S DEGREE - UNIVERSITY OF KENTUCKY

Bachelor of Arts in Secondary Spanish Education August 2001-May 2005

GPA: $3.17 / 4.0$

SCHOOL, COMMUNITY \& VOLUNTEER ACTIVITIES:

MEMBER OF FCPS ASSOCIATE PRINCIPAL STEERING COMMITTEE

August 2018 - Present

MEMBER OF DISTRICT WORLD LANGUAGE PROGRAM REVIEW TEAM

August 2015 - Present

- MEMBER OF SUPERINTENDENT'S ADVISORY COMMITTEE August 2013 - May 2016

* MEMBER OF PAUL LAURENCE DUNBAR DRESS CODE COMMITTEE

January 2011 - May 2013

MENTOR TEACHER FOR STUDENT TEACHING PLACEMENTS Spring Semester 2011 and 2013

* CROSS COUNTRY COACH - PAUL LAURENCE DUNBAR

August 2010 - May 2013

* ASSISTANT TRACK COACH - PAUL LAURENCE DUNBAR HIGH SCHOOL

December 2007-May 2013

* ROBINSON SCHOLAR SELECTION COMMITTEE MEMBER UNIVERSITY OF KENTUCKY

2007-2014 


\title{
* PRESENTER AT KENTUCKY WORLD LANGUAGE CONFERENCE \\ April 2007
}

SKILLS:

* Fluent in Spanish (Reading, Writing, Speaking)

* Highly skilled with computers and technology

* Ability to work well with diverse populations

Ability to create documents/school master schedules and implement programs in schools

* Extremely organized and handles responsibility well

* Knowledge of all KHSAA rules and regulations

\section{REFERENCES:}

\author{
* Tina Stevenson, STEAM Principal \\ * Eric Ridd, STEAM Guidance Counselor
}

* Dr. Lu Young, UK Professor and former Chief Academic Officer, Fayette County

* Dr. Justin Bathon, UK Professor College of Education and STEAM Partner 